\title{
Catalytic Space Engineering as a Strategy to Activate C-H Oxidation on 5-Methylcytosine in Mammalian Genome
}

\author{
Sushma Sappa, Debasis Dey, Babu Sudhamalla, Kabirul Islam* \\ Department of Chemistry, Pittsburgh, Pittsburgh PA 15260
}

\section{Supporting Material}

1. General materials, methods, and equipment $\quad$ S2

2. Synthesis and characterization of $5 \mathrm{hmC}, 5 \mathrm{fC}$ and $5 \mathrm{caC}$ phosphoramidites $\mathbf{S 1 - 3} \quad \mathrm{S} 3$

3. Synthesis and characterization of oligonucleotides $\quad \mathrm{S} 12$

4. Mutagenesis, Expression, and purification of TET1 and 2 proteins $\quad$ S12

5. Relative quantification of $5 \mathrm{mC}$ and $5 \mathrm{mC}_{\mathrm{ox}}$ DNAs for standard curve $\mathrm{S} 13$

$\begin{array}{ll}\text { 6. In-vitro TET demethylase assay } & \mathrm{S} 14\end{array}$

7. Time-dependent TET demethylase assay using modified DNA substrates $\quad$ S14

8. Acquisition and analysis of MALDI data $\quad$ S15

9. Demethylase assay and bisulfite treatment on 76-mer dsDNA containing 5mC $\quad$ S15

10. Mammalian cell culture and genomic DNA isolation $\quad$ S16

11. TET activity on genomic DNA and dot-blot assay $\quad$ S16

$\begin{array}{ll}\text { 12. Biotin-labelling of } 5 \mathrm{caC} \text { in genomic DNA samples } & \mathrm{S} 17\end{array}$

13. Overexpression of the catalytic domain of TET2 in HEK293T cells S18

14. Analysis of expression of DACT1 in HEK293T cells overexpressed with TET2 S19

15. DNA Immunoprecipitation (DIP) $\quad$ S19

16. Genomic variation analysis of human TET1-3 $\quad$ S20

$\begin{array}{ll}\text { 17. Supplementary figures and tables } & \text { S21 }\end{array}$

18. References $\quad$ S66 


\section{General materials, methods, and equipment}

Chemicals: All chemicals were purchased from established vendors (e.g., Sigma-Aldrich, Acros Organics) and used without purification unless otherwise noted. Optima grade acetonitrile was obtained from Fisher Scientific and degassed under vacuum prior to use during HPLC purification. Analytical thin layer chromatography (TLC) was performed using EMD 250-micron flexible aluminum backed, UV F 254 pre-coated silica gel plates and visualized under UV light (254 nm) or by staining with phosphomolybdic acid, ninhydrin or anisaldehyde. Reaction solvents were removed by a Büchi rotary evaporator equipped with a dry ice-acetone condenser. Analytic and preparative HPLC was carried out on an Agilent 1220 Infinity HPLC with diode array detector. Concentration and lyophilization of aqueous samples were performed using Savant Sc210A SpeedVac Concentrator (Thermo), followed by Labconco Freeze-Dryer system.

Proton nuclear magnetic resonance spectra $\left({ }^{1} \mathrm{H}\right.$ NMR) were recorded on Bruker Ultrashield ${ }^{\mathrm{TM}}$ Plus $600 / 500 / 400 / 300 \mathrm{MHz}$ instruments at $24{ }^{\circ} \mathrm{C}$. Chemical shifts of ${ }^{1} \mathrm{H}$ and ${ }^{13} \mathrm{C}$ NMR spectra are reported as $\delta$ in units of parts per million (ppm) relative to tetramethylsilane $(\delta 0.0)$ or residual solvent signals: chloroform-d $\left(\delta 7.26\right.$, singlet), methanol- $\mathrm{d}_{4}(\delta 3.30$, quintet), and deuterium oxide$\mathrm{d}_{2}(\delta 4.80$, singlet). Coupling constants are expressed in Hz. Mass spectra were collected at the UPITT MASSSPEC lab on a Q-Exactive ${ }^{\mathrm{TM}}$ Thermo Scientific LC-MS with electron spray ionization (ESI) probe.

Plasmids, mutagenic primers, cell lines and antibodies: All the plasmids for bacterial expression are obtained as gifts from individual laboratories or purchased from Addgene. Details of these constructs are given in Table S2. Mutagenic primers are obtained from Integrated DNA Technologies (Table S3). Competent bacterial cells used for protein expression and mutagenesis are given in Table S4. Human embryonic kidney 293T (HEK293T) cells are obtained from the American Type Culture Collection (ATCC) and used in the current study following manufacturer's protocol (details in section 13). All the antibodies used in the current study are purchased from established vendors and used following manufacturer's protocol (details in sections 10, 13, 14). 


\section{Synthesis and characterization of $5 \mathrm{hmC}, 5 \mathrm{fC}$ and $5 \mathrm{caC}$ phosphoramidites $\mathrm{S1-3}$}

5hmC, 5fC and 5caC phosphoramidites S1-3 were synthesized directly following or slightly modifying the reported methods as shown in Scheme S1-S3. ${ }^{1-5}$ The detailed experimental methods and analytical data are provided below. The corresponding ${ }^{1} \mathrm{H} \mathrm{NMR},{ }^{13} \mathrm{C}$ NMR and HRMS spectra are provided in Figure S23 - S42.

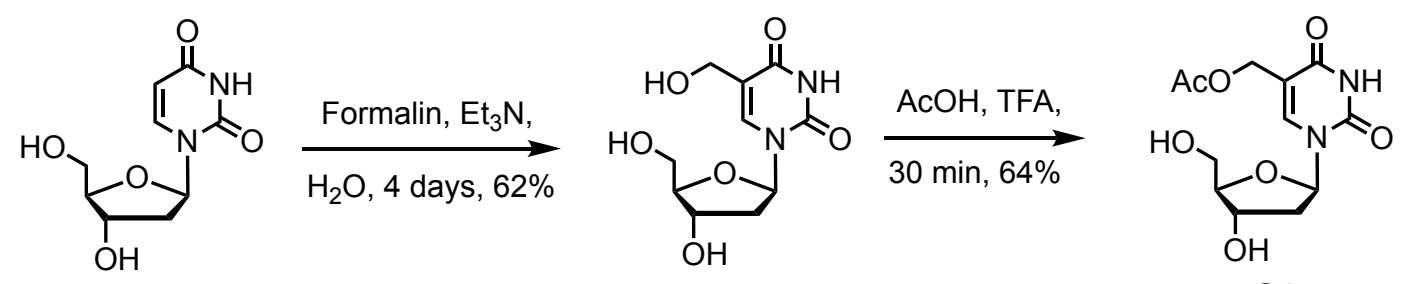

S4

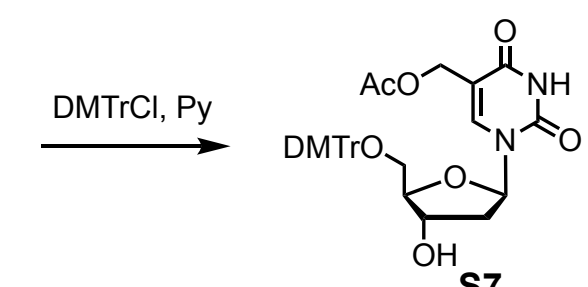

S7

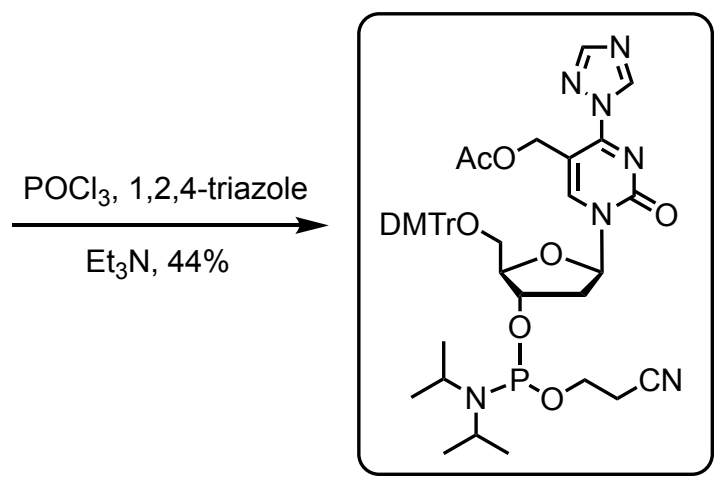

S1
S5

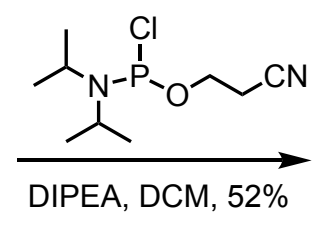

DIPEA, DCM, $52 \%$<smiles>CC(=O)OCc1cn(C2CC(OP(OCCC#N)N(C(C)C)C(C)C)CC(COC(C)C)O2)c(=O)[nH]c1=O</smiles>

Scheme S1: Synthetic scheme towards protected $5 \mathrm{hmC}$ phosphoramidite S1<smiles>O=c1[nH]c(=O)n(C2CC(O)CO2)cc1CO</smiles>

S5

Deoxyuridine S4 (5.25 g, $23.0 \mathrm{mmol})$ and paraformaldehyde (3.11 g, 103.5 mmol) were added into $250 \mathrm{~mL}$ round-bottom flask with two necks and dissolved in $80 \mathrm{~mL} 0.5 \mathrm{~mol} / \mathrm{L}$ triethylamine aqueous solution. The mixture was stirred at $60^{\circ} \mathrm{C}$ for 4 days. During the reaction, more paraformaldehyde ( $4.49 \mathrm{~g}$, $149.5 \mathrm{mmol})$, triethylamine $(1 \mathrm{~mL})$, and water $(10 \mathrm{~mL})$ was added into reaction mixture each day. After reaction finished, the mixture was concentrated in vacuo to remove the 
solvent. The residue was Purified by column chromatography to obtain S5 $(4.11 \mathrm{~g}, 62 \%)$ as white solid.

${ }^{1}$ H NMR (METHANOL-d 4 , 300MHz): $\boldsymbol{\delta}=7.96(\mathrm{~s}, 1 \mathrm{H}), 6.30(\mathrm{t}, J=6.8 \mathrm{~Hz}, 1 \mathrm{H}), 4.36$ - 4.44 (m, $1 \mathrm{H}), 4.32$ (s, $2 \mathrm{H}), 3.92$ (q, J=3.5 Hz, $1 \mathrm{H}), 3.67$ - 3.85 (m, $2 \mathrm{H}), 2.16$ - 2.34 (m, $2 \mathrm{H})$ ppm.

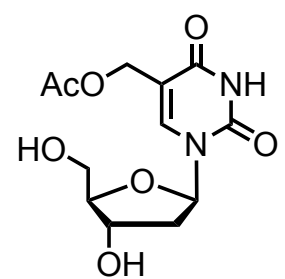

S6

The mixture of S5 (0.5g, $1.94 \mathrm{mmol}, 1.0$ equiv.), AcOH (30 mL) and TFA (200 $\mathrm{mL})$ was directly put into a preheated oil bath $\left(120^{\circ} \mathrm{C}\right)$. The solution was heated to reflux for $0.5 \mathrm{~h}$ and subsequently cooled and concentrated in vacuo. The crude product was purified by column chromatography $\left(\mathrm{CHCl}_{3} / \mathrm{MeOH} 99: 1 \rightarrow 10: 1\right)$ to yield S6 (0.374 g, 64\%) as white crystalline solids.

${ }^{1}$ H NMR (METHANOL-d4, 400MHz): $\boldsymbol{\delta}=8.17$ (s, $\left.1 \mathrm{H}\right), 6.27$ (t, $\left.J=6.7 \mathrm{~Hz}, 1 \mathrm{H}\right), 4.78$ - 4.83 (m, $2 \mathrm{H}), 4.36$ - 4.43 (m, $1 \mathrm{H}), 3.93$ (q, $J=3.4 \mathrm{~Hz}, 1 \mathrm{H}), 3.81$ (dd, $J=12.0,3.1 \mathrm{~Hz}, 1 \mathrm{H}), 3.74$ (dd, $J=12.0$, $3.6 \mathrm{~Hz}, 1 \mathrm{H}), 2.29$ (dd, J=6.1, 3.6 Hz, $1 \mathrm{H}), 2.15$ - 2.26 (m, $1 \mathrm{H}), 2.04$ (s, $3 \mathrm{H}) \mathrm{ppm}$.

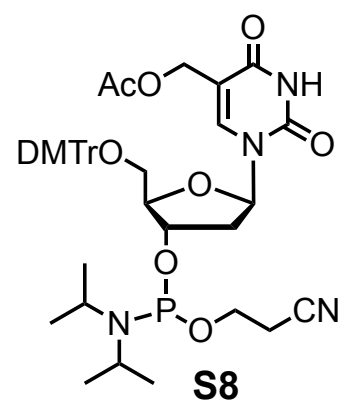

To a stirring solution of $\mathbf{S} 7(200 \mathrm{mg}, 0.33 \mathrm{mmol})$ in $\mathrm{CH}_{2} \mathrm{Cl}_{2}(5 \mathrm{~mL})$ was added N,N-diisopropylethylamine $(0.43 \mathrm{~mL}, 2.49 \mathrm{mmol}, 7.5$ equiv. $)$ under argon followed by 2-cyanoethyl N,N-diisopropylchlorophosphoramidite $(0.13 \mathrm{~mL}, 0.58 \mathrm{mmol})$. After the reaction mixture was stirred at room temperature for $1.5 \mathrm{~h}, \mathrm{CH}_{2} \mathrm{Cl}_{2}(30 \mathrm{~mL})$ was added. The mixture was washed with $5 \%$ aqueous $\mathrm{NaHCO}_{3}$ and brine, dried over $\mathrm{Na}_{2} \mathrm{SO}_{4}$, and concentrated to dryness. The residue was purified by silica gel chromatography, eluting with $50 \%$ ethylacetate in hexane containing $0.2 \% \mathrm{Et}_{3} \mathrm{~N}$, to get $\mathbf{S 8}(0.14 \mathrm{~g}, 52 \%)$ as white foam.

${ }^{1}$ H NMR (ACETONITRILE-d3, 400MHz): $\boldsymbol{\delta}=7.76(\mathrm{~d}, J=10.9 \mathrm{~Hz}, 1 \mathrm{H}), 7.36$ - 7.46 (m, $\left.2 \mathrm{H}\right)$, 7.26 - $7.36(\mathrm{~m}, 6 \mathrm{H}), 7.19$ - $7.26(\mathrm{~m}, 1 \mathrm{H}), 6.80$ - 6.92 (m, $4 \mathrm{H}), 6.21$ (q, J=6.7 Hz, $1 \mathrm{H}), 4.59$ (td, $J=6.6,3.8 \mathrm{~Hz}, 1 \mathrm{H}), 4.28$ - 4.43 (m, $2 \mathrm{H}), 4.02$ - 4.15 (m, $3 \mathrm{H}), 3.79$ - 3.88 (m, $1 \mathrm{H}), 3.71$ - 3.79 (m, 7 H), $3.42-3.71(\mathrm{~m}, 4 \mathrm{H}), 3.28-3.38(\mathrm{~m}, 2 \mathrm{H}), 2.76$ (t, J=6.0 Hz, $1 \mathrm{H}), 2.64$ (t, J=6.0 Hz, 1 H), 2.49 - $2.55(\mathrm{~m}, 1 \mathrm{H}), 2.30$ - 2.49 (m, $2 \mathrm{H}), 1.81$ - $1.84(\mathrm{~m}, 3 \mathrm{H}), 1.13$ - 1.20 (m, 9 H), 1.02 1.07 (m, $3 \mathrm{H})$ ppm. 
${ }^{31}$ P NMR: 148.90, 148.94

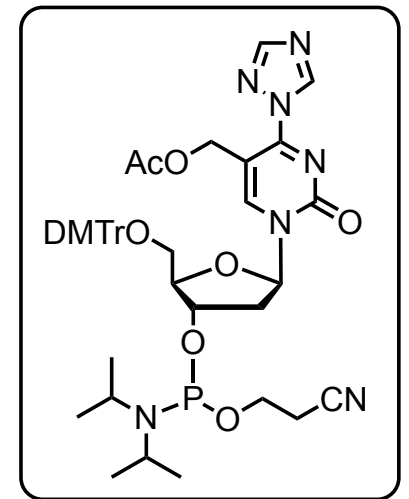

S1

To a solution of $\mathbf{S 8}(140 \mathrm{mg}, 0.17 \mathrm{mmol})$ in $\mathrm{CH}_{3} \mathrm{CN}(5 \mathrm{~mL})$ were added $\mathrm{Et}_{3} \mathrm{~N}(0.61 \mathrm{~mL})$ and 1,2,4-triazole (241 mg, $3.49 \mathrm{mmol}, 2.6$ equiv.), and the mixture was cooled to $0{ }^{\circ} \mathrm{C}$. $\mathrm{POCl}_{3}(42 \mu \mathrm{L}, 0.45 \mathrm{mmol}, 2.6$ equiv.) was added, and the mixture was stirred at $0^{\circ} \mathrm{C}$ for $0.5 \mathrm{~h}$ and at $\mathrm{rt}$ for $1 \mathrm{~h}$. Additional $\mathrm{POCl}_{3}(21 \mu \mathrm{L})$ was added to the mixture and, was stirred at rt for $5 \mathrm{~h}$. $\mathrm{CH}_{2} \mathrm{Cl}_{2}(100 \mathrm{~mL})$ was added, and the mixture was washed with water, $5 \% \mathrm{NaHCO}_{3}$, and brine, dried over $\mathrm{Na}_{2} \mathrm{SO}_{4}$, and concentrated to dryness. The residue was purified by silica gel chromatography, eluting with 6-10\% acetone in $\mathrm{CH}_{2} \mathrm{Cl}_{2}$ containing $0.2 \% \mathrm{Et}_{3} \mathrm{~N}$, to obtain $\mathbf{S 1}(65 \mathrm{mg}$, $44 \%$ ) as white foam.

${ }^{1}$ H NMR (ACETONITRILE-d3, 300MHz): $\boldsymbol{\delta}=9.19$ (s, $\left.1 \mathrm{H}\right), 8.41$ - 8.50 (m, $\left.1 \mathrm{H}\right), 8.12$ (s, $\left.1 \mathrm{H}\right)$, 7.39 - $7.46(\mathrm{~m}, 2 \mathrm{H}), 7.22$ - $7.34(\mathrm{~m}, 7 \mathrm{H}), 6.81$ - 6.89 (m, $4 \mathrm{H}), 6.10$ - 6.19 (m, $1 \mathrm{H}), 5.01$ (d, $J=12.5 \mathrm{~Hz}, 1 \mathrm{H}), 4.79$ (t, $J=12.8 \mathrm{~Hz}, 1 \mathrm{H}), 4.48$ - 4.64 (m, $2 \mathrm{H}), 4.19$ - 4.41 (m, $2 \mathrm{H}), 3.74$ - 3.77 (m, 7 H), 3.51 - $3.70(\mathrm{~m}, 4 \mathrm{H}), 3.39$ - $3.46(\mathrm{~m}, 1 \mathrm{H}), 2.60$ - 2.70 (m, $3 \mathrm{H}), 2.53$ (t, J=5.9 Hz, $1 \mathrm{H})$, 2.47 (s, $1 \mathrm{H}), 1.13-1.20(\mathrm{~m}, 9 \mathrm{H}), 1.05$ (d, $J=7.0 \mathrm{~Hz}, 3 \mathrm{H}) \mathrm{ppm}$.

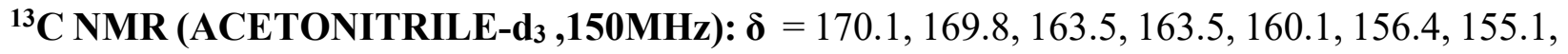
$154.3,146.5,146.4,146.2,137.2$, 137.1, 137.1, 137.1, 131.5, 131.5, 131.4, 129.4, 129.4, 129.3, 129.3, 128.2, 128.2, 120.0, 119.8, 119.6, 91.0, 90.9, 88.1, 88.0, 87.6, 67.2, 67.2, 65.1, 65.1, 64.8, $64.3,60.3,60.2,59.9,59.9,59.8,59.8,58.8,58.7,56.3,56.3,51.4,44.5,44.4,25.3,25.3,25.2$, 25.2, 21.4, 21.4, 21.4, 21.3, 21.3, 17.6, $17.6 \mathrm{ppm}$

HRMS m/z $[\mathbf{M}+\mathbf{H}]^{+}$calcd. for $\mathrm{C}_{44} \mathrm{H}_{53} \mathrm{O}_{9} \mathrm{~N}_{7} \mathrm{P}: 854.36737$, found 854.36738 (4.3 ppm). 

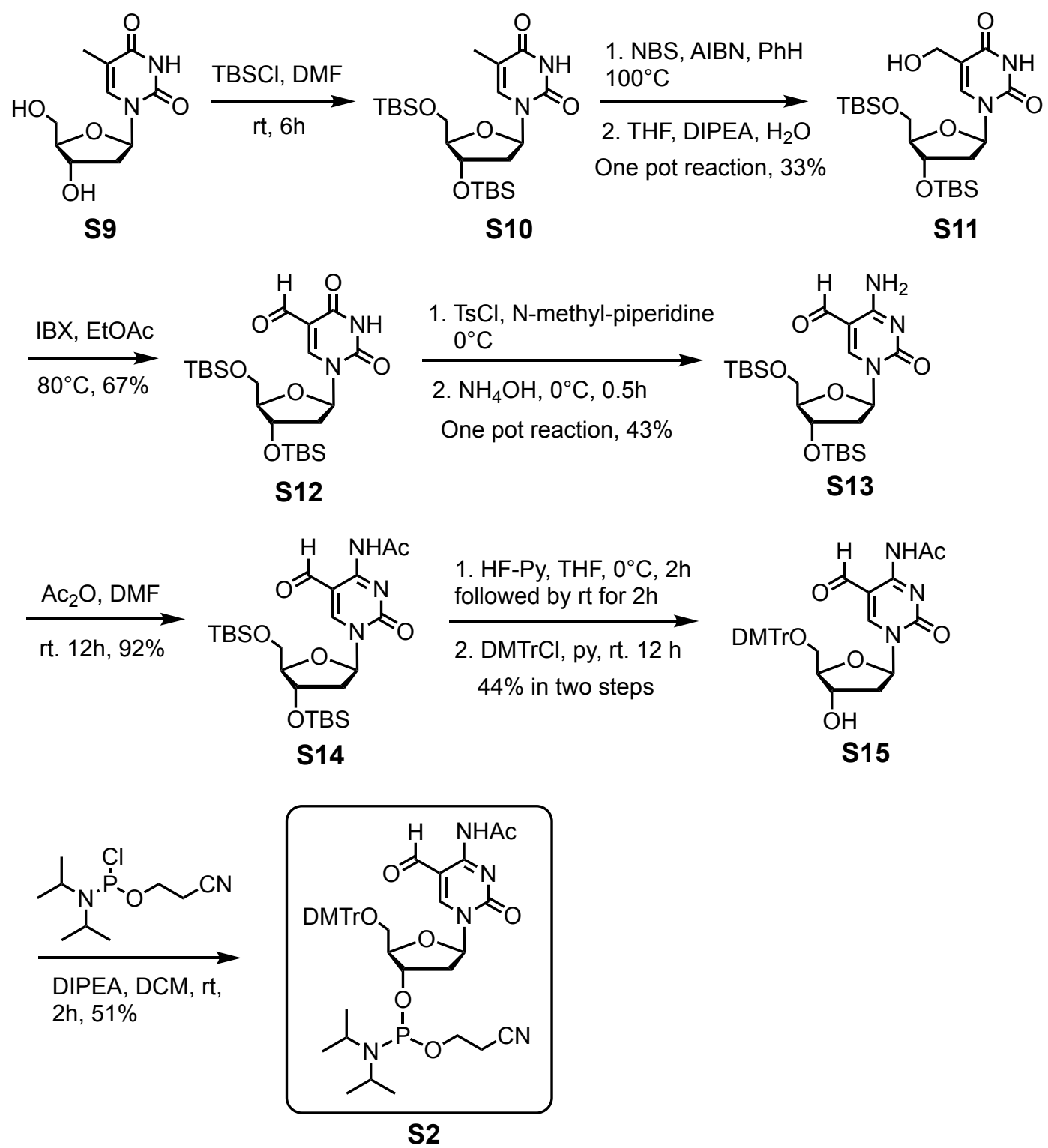

Scheme S2: Synthetic scheme towards protected 5fC phosphoramidite S2 


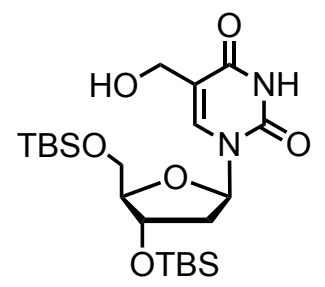

S11

A mixture of $\mathbf{S 1 0}(2.0 \mathrm{~g}, 4.25 \mathrm{mmol}, 1.0$ eq.), AIBN (0.14 g, $0.85 \mathrm{mmol}, 0.2$ eq.) and NBS (1.66 g, $9.36 \mathrm{mmol}, 2.2$ eq.) were suspended in benzene (50 mL) and directly put into a preheated oil bath $\left(100^{\circ} \mathrm{C}\right)$. The solution was heated to reflux for $1 \mathrm{~h}$ and subsequently concentrated in vacuo. The crude product was dissolved in THF (20 mL), DIPEA (1.41 mL, 8.07 mmol, 1.9 eq.) and $\mathrm{H}_{2} \mathrm{O}$ (1.84 mL, $102 \mathrm{mmol}, 24$ eq.). The solution was stirred for $1 \mathrm{~h}$ at $50^{\circ} \mathrm{C}$, subsequently diluted with EtOAc $(40 \mathrm{~mL})$, extracted twice with diluted $\mathrm{NH}_{4} \mathrm{Cl}$ and once with $\mathrm{H}_{2} \mathrm{O}$, dried over $\mathrm{Na}_{2} \mathrm{SO}_{4}$ and concentrated in vacuo. The crude product was purified by column chromatography (DCM/MeOH 99:1 $\rightarrow$ 50:1 $\rightarrow$ 10:1) to yield S11 $(0.7 \mathrm{~g}, 33 \%)$ as a pale-yellow oil.

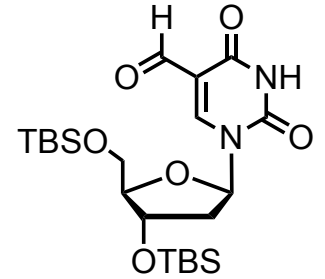

S12

A mixture of S11 (0.677g, 1.39 mmol, 1.0 eq.), iodoxybenzoic acid (IBX) (0.584 g, $2.09 \mathrm{mmol}, 1.5$ eq.) were suspended in ethyl acetate $(20 \mathrm{~mL})$ and directly put into a preheated oil bath $\left(80^{\circ} \mathrm{C}\right)$. The solution was heated at that temperature for $2.5 \mathrm{~h}$ and subsequently cooled, filtered through a pad of celite and filtrate was concentrated in vacuo. The crude product was purified by column chromatography (EtOAc/Hexanes 90:10 $\rightarrow$ 60:40) to yield $\mathbf{S 1 2}(0.45 \mathrm{~g}, 67 \%)$ as colorless liquid.

${ }^{1}$ H NMR (CHLOROFORM-d, 500MHz): $\delta=10.00$ (s, 1 H), 9.99 (s, 1 H), 8.54 (s, 1 H), 6.23 $(\mathrm{dd}, J=7.6,5.8 \mathrm{~Hz}, 1 \mathrm{H}), 4.41(\mathrm{dt}, J=5.5,2.1 \mathrm{~Hz}, 1 \mathrm{H}), 4.06$ (q, $J=2.5 \mathrm{~Hz}, 1 \mathrm{H}), 3.88$ (dd, $J=11.4$, $2.9 \mathrm{~Hz}, 1 \mathrm{H}), 3.77$ (dd, $J=11.4,2.6 \mathrm{~Hz}, 1 \mathrm{H}), 2.45$ (ddd, J=13.3, 5.8, 2.1 Hz, $1 \mathrm{H}$ ), 2.05 (ddd, $J=13.4,7.6,5.8 \mathrm{~Hz}, 1 \mathrm{H}), 0.88(\mathrm{~d}, J=6.4 \mathrm{~Hz}, 19 \mathrm{H}), 0.05-0.12(\mathrm{~m}, 12 \mathrm{H}) \mathrm{ppm}$.

${ }^{13}$ C NMR (CHLOROFORM-d, 125MHz): $\delta=185.7,162.4,149.4,145.3,110.9,89.1,87.1$, $72.8,63.0,42.4,25.9,25.7,18.3,17.9,-4.7,-4.9,-5.6,-5.7 \mathrm{ppm}$.

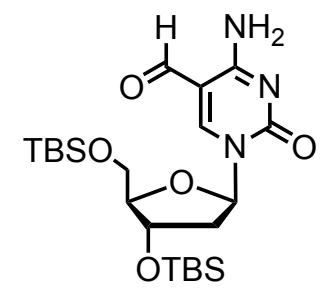

S13

To an ice-cold solution of $\mathbf{S 1 2}$ (0.4 g, 0.825 mmol,1equiv.), Nmethylpiperidine (0.12 mL, $0.9 \mathrm{mmol}, 1.2$ equiv.) and $\mathrm{Et}_{3} \mathrm{~N}(0.253 \mathrm{~mL}, 1.82$ mmol, 2.2 equiv. $)$ in acetonitrile $(10 \mathrm{~mL})$ was added $\mathrm{TsCl}(0.346 \mathrm{~g}, 1.82$ mmol, 2.2 equiv.). The reaction mixture was stirred at that temperature for $4 \mathrm{~h}$ after which $\mathrm{NH}_{4} \mathrm{OH}(2 \mathrm{~mL})$ was added and stirred for another $30 \mathrm{~min}$. The reaction mixture subsequently diluted with EtOAc $(40 \mathrm{~mL})$, extracted twice with sat $\mathrm{NaCl}$, dried 
over $\mathrm{Na}_{2} \mathrm{SO}_{4}$ and concentrated in vacuo. The residue was chromatographed $(50-70 \%$ EtOAc in hexanes) to obtain $\mathbf{S 1 3}$ (0.17 g, 43\%) as white floppy solids.

${ }^{1}$ H NMR (CHLOROFORM-d, 500MHz): $\boldsymbol{\delta}=9.46$ (s, $\left.1 \mathrm{H}\right), 8.49$ (s, $\left.1 \mathrm{H}\right), 8.18$ (s, $\left.1 \mathrm{H}\right), 7.82$ (br. s., $1 \mathrm{H}), 6.18$ (t, $J=6.2 \mathrm{~Hz}, 1 \mathrm{H}), 4.29$ - 4.38 (m, $1 \mathrm{H}), 4.02$ (q, $J=2.6 \mathrm{~Hz}, 1 \mathrm{H}), 3.93$ (dd, J=11.6, $2.6 \mathrm{~Hz}, 1 \mathrm{H}), 3.76$ (dd, $J=11.6,2.6 \mathrm{~Hz}, 1 \mathrm{H}), 2.58$ (ddd, $J=13.5,6.1,3.8 \mathrm{~Hz}, 1 \mathrm{H}), 1.96$ - 2.11 (m, $1 \mathrm{H}), 0.87(\mathrm{~d}, J=4.0 \mathrm{~Hz}, 18 \mathrm{H}), 0.05$ (d, $J=5.2 \mathrm{~Hz}, 6 \mathrm{H}), 0.07$ (d, $J=6.7 \mathrm{~Hz}, 6 \mathrm{H}) \mathrm{ppm}$.

${ }^{13}$ C NMR (CHLOROFORM-d, 125MHz): $\boldsymbol{\delta}=187.0,162.8,153.2,152.8,105.0,88.5,87.6$, $71.5,62.5,42.8,25.8,25.6,18.3,17.9,-4.6,-5.0,-5.4,-5.4 \mathrm{ppm}$.

HRMS m/z [M+H] $]^{+}$calcd. for $\mathrm{C}_{22} \mathrm{H}_{41} \mathrm{~N}_{3} \mathrm{O}_{5} \mathrm{Si}_{2}$ : 484.2658, found 484.2657

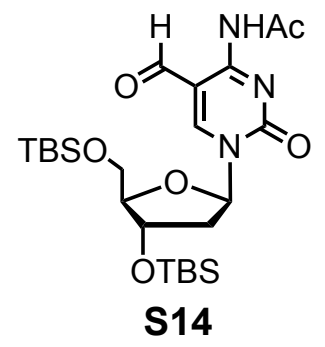

To a stirring solution of $\mathbf{S 1 3}$ (0.26 g, $0.537 \mathrm{mmol}$, 1equiv.) in anhydrous DMF $(5 \mathrm{~mL})$ was added $\mathrm{Ac}_{2} \mathrm{O}(0.1 \mathrm{~mL}, 1.07 \mathrm{mmol}, 2$ equiv.) The mixture was stirred at rt for $12 \mathrm{~h}$. TLC indicated complete conversion of starting material. The reaction was concentrated in vacuo. The residue was purified by flash chromatography (EtOAc: hexane 3:7) to obtain S14 (0.26 g, 92\%) as colorless

solid.

${ }^{1}$ H NMR (CHLOROFORM-d, 500MHz): $\delta=10.69$ (br. s., $1 \mathrm{H}$ ), 9.47 (s, $\left.1 \mathrm{H}\right), 8.68$ (s, $1 \mathrm{H}$ ), $6.16(\mathrm{t}, J=6.1 \mathrm{~Hz}, 1 \mathrm{H}), 4.32-4.37$ (m, $1 \mathrm{H}), 4.08$ (q, $J=2.5 \mathrm{~Hz}, 1 \mathrm{H}), 3.96$ (dd, $J=11.7,2.5 \mathrm{~Hz}, 1$ H), $3.78(\mathrm{dd}, J=11.6,2.4 \mathrm{~Hz}, 1 \mathrm{H}), 2.63-2.67$ (m, $1 \mathrm{H}), 2.62$ (s, $3 \mathrm{H}), 2.09$ (dt, J=13.6, 6.1 Hz, 1 $\mathrm{H}), 0.87$ (d, $J=4.7 \mathrm{~Hz}, 18 \mathrm{H}), 0.05-0.08$ (m, $12 \mathrm{H}) \mathrm{ppm}$.

${ }^{13}$ C NMR (CHLOROFORM-d, 125MHz): $\delta=186.9,171.6,158.8,153.9,152.4,104.8,89.0$, $88.3,71.5,62.5,42.7,27.2,25.8,25.6,18.3,17.9,-4.6,-5.0,-5.3,-5.4 \mathrm{ppm}$.

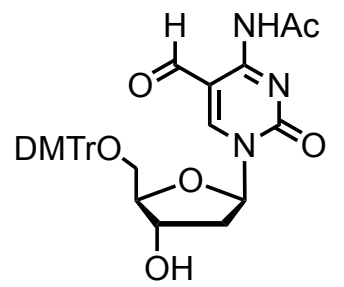

S15

To an ice cold and stirring solution of S14 (0.4g, $0.76 \mathrm{mmol}, 1$ equiv.) (in polypropylene falcon tube) in THF $(10 \mathrm{~mL})$ was added HF.py complex solution (1.0 mL, 7.6mmol, 10 equiv.). The reaction mixture was stirred at that temperature for $2 \mathrm{~h}$ and then slowly allowed to come to $\mathrm{rt}$ and stirred for 2 hrs. By which time TLC shows complete conversion of starting compound.

Solid $\mathrm{NaHCO}_{3}$ was added to reaction and stirred at $\mathrm{rt}$ for $1 \mathrm{~h}$. The reaction mixture was then filtered, 
and the filtrate was concentrated under reduced pressure. The residue was carried forward for $\mathrm{DMTrCl}$ reaction. In a round bottomed flask the residue and $\mathrm{DMTrCl}(0.271 \mathrm{~g}, 0.79 \mathrm{mmol}, 1.05$ equiv.) was placed in high vacuum for $40 \mathrm{~min}$.; to this $5 \mathrm{~mL}$ of pyridine was added. The reaction mixture was stirred at room temperature for $12 \mathrm{~h}$. The reaction was quenched with the addition of $0.5 \mathrm{ml}$ of methanol. The volatiles were evaporated and the residue was chromatographed $\left(\mathrm{CHCl}_{3}: \mathrm{MeOH}\right.$ 99:1 to $\left.97: 3\right)$ to obtain $\mathbf{S 1 5}(0.2 \mathrm{~g}, 44 \%)$ as solid crystalline material.

${ }^{1}$ H NMR (CHLOROFORM-d, 300MHz): $\boldsymbol{\delta}=10.70$ (br. s., $1 \mathrm{H}$ ), 8.81 (s, $1 \mathrm{H}$ ), 8.30 (s, $1 \mathrm{H}$ ), 7.29 - 7.34 (m, 6 H), 7.23 (d, J=8.7 Hz, 3 H), 6.84 (d, $J=8.7$ Hz, 4 H), 6.25 (t, $J=5.5$ Hz, 1 H), 4.61 - $4.72(\mathrm{~m}, 1 \mathrm{H}), 4.16$ - 4.24 (m, $1 \mathrm{H}), 3.80$ (s, $6 \mathrm{H}), 3.57$ - 3.65 (m, $1 \mathrm{H}), 3.46(\mathrm{dd}, J=10.9,2.7 \mathrm{~Hz}$, $1 \mathrm{H}), 2.71-2.77$ (m, $1 \mathrm{H}), 2.62$ (s, $3 \mathrm{H}), 2.46$ (dt, $J=13.7,5.6 \mathrm{~Hz}, 1 \mathrm{H}) \mathrm{ppm}$.

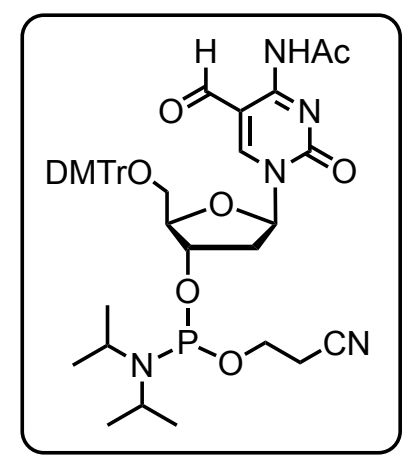

S2

To a stirring solution of $\mathbf{S 1 5}(0.2 \mathrm{~g}, 0.333 \mathrm{mmol})$ in dichloromethane (8 $\mathrm{mL})$ were added $N, N$-diisopropylethylamine $(0.435 \mathrm{~mL}, 2.5 \mathrm{mmol}, 7.5$ equiv.) under argon followed by 2-cyanoethyl N,N-diisopropyl chlorophosphoramidite ( $0.13 \mathrm{~mL}, 0.58 \mathrm{mmol}, 1.75$ equiv.). After the reaction mixture was stirred at room temperature for $2 \mathrm{~h}$, the reaction mixture was concentrated and directly purified via flash chromatography (EtOAc: hexane 7:3 to 10:0) to give $\mathbf{S 2}(0.136 \mathrm{~g}, 51 \%)$ as white foam.

${ }^{1}$ H NMR (ACETONITRILE-d ${ }_{3}, \mathbf{5 0 0 M H z}: \boldsymbol{\delta}=10.64$ (br. s., $1 \mathrm{H}$ ), 8.73 (d, $J=13.0 \mathrm{~Hz}, 1 \mathrm{H}$ ), 8.45 (d, J=3.7 Hz, 1 H), 7.40 - 7.44 (m, 2 H), 7.26 - 7.33 (m, 8 H), 6.84 - 6.89 (m, 4 H), 6.03 - 6.13 (m, $1 \mathrm{H}), 4.63$ - $4.76(\mathrm{~m}, 1 \mathrm{H}), 4.15$ - 4.24 (m, $1 \mathrm{H}), 3.81$ (d, $J=7.8 \mathrm{~Hz}, 1 \mathrm{H}), 3.74$ - 3.77 (m, $7 \mathrm{H}), 3.49$ - 3.68 (m, 5 H), 3.39 - 3.49 (m, 2 H), 2.62 - 2.72 (m, 2 H), 2.51 - 2.57 (m, 2 H), 2.48 (d, J=1.2 Hz, $3 \mathrm{H}), 1.13-1.17$ (m, $9 \mathrm{H}), 1.04(\mathrm{~d}, J=6.9 \mathrm{~Hz}, 3 \mathrm{H}) \mathrm{ppm}$.

${ }^{13}$ C NMR (ACETONITRILE-d, $\left.125 \mathrm{MHz}\right): \boldsymbol{\delta}=189.0,189.0,171.5,171.2,159.5,155.5,155.4$, 153.1, 153.0, 145.0, 145.0, 136.1, 136.0, 135.9, 130.8, 130.7, 128.8, 128.8, 128.6, 127.8, 113.8, $105.3,105.3,88.4,88.3,87.3,86.3,86.3,86.1,86.1,72.2,72.1,71.4,71.4,62.6,62.3,60.5,59.1$, 
59.0, 59.0, 58.8, 55.5, 55.5, 43.7, 43.7, 43.6, 43.6, 40.8, 40.4, 40.4, 26.7, 24.5, 24.5, 24.5, 24.4, 24.4, 24.4, 20.7, 20.7, 20.6, 20.6, $14.1 \mathrm{ppm}$.

${ }^{31}$ P NMR (ACETONITRILE-d, 200MHz): $\boldsymbol{\delta}=148.43,148.36$ ppm.

HRMS m/z [M+H] $]^{+}$calcd. for $\mathrm{C}_{42} \mathrm{H}_{52} \mathrm{~N}_{5} \mathrm{O} 9 \mathrm{P}: 800.3418$, found 800.3398 (-2.5 ppm)
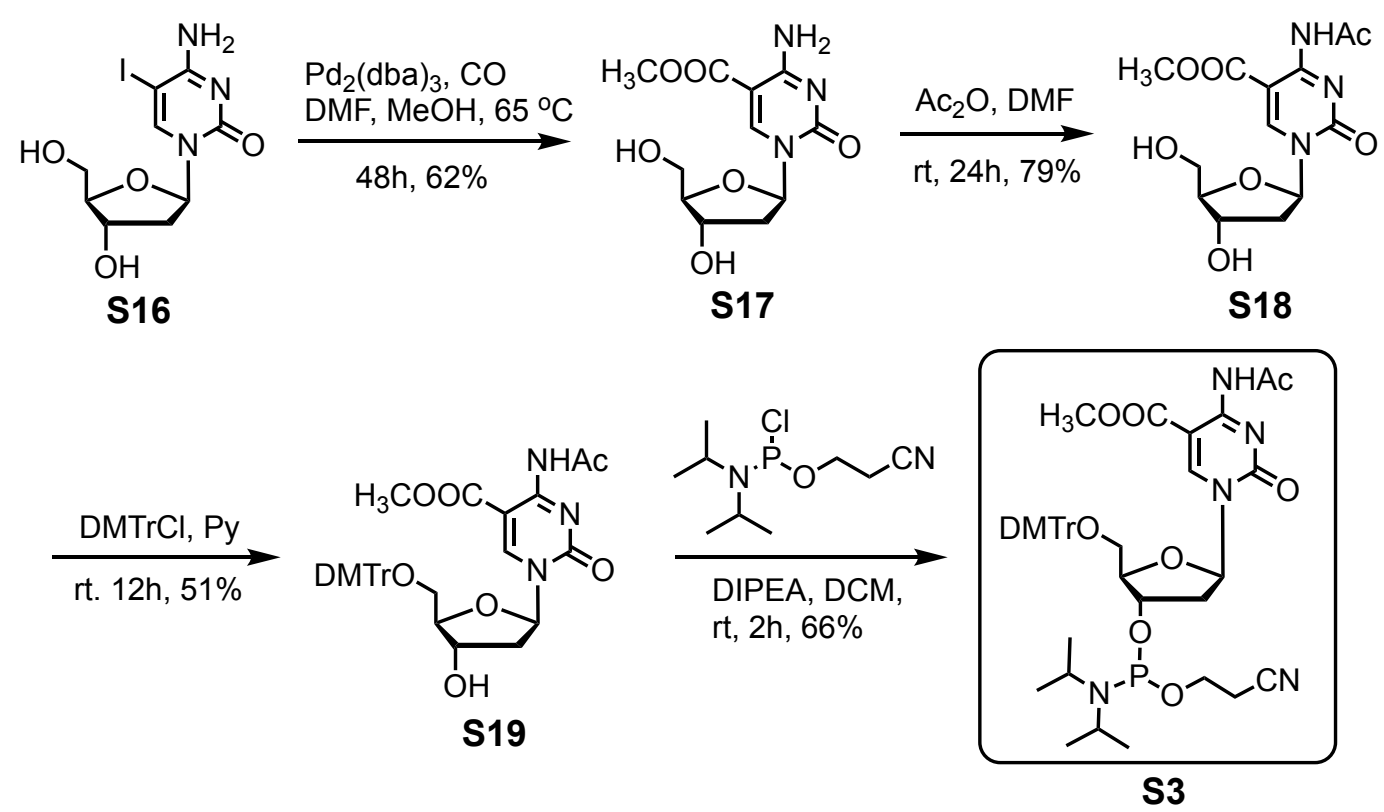

Scheme S3: Synthetic scheme towards protected 5caC phosphoramidite S3<smiles>CC(=O)c1cn(C2CC(O)C(CO)O2)c(=O)nc1N</smiles>

S17

A mixture of 5-Iodo-2-deoxycytidine S16 (0.70 g, $1.9 \mathrm{mmol}, 1.0$ equiv.), $\mathrm{Pd}_{2}(\mathrm{dba})_{3}(0.181 \mathrm{~g}, 0.19 \mathrm{mmol}, 10 \mathrm{~mol} \%), \mathrm{PPh}_{3}(0.337 \mathrm{~g}, 1.29 \mathrm{mmol}, 0.65$ equiv.), $\mathrm{Et}_{3} \mathrm{~N}$ (0.488 mL, $3.57 \mathrm{mmol}, 1.8$ equiv.) and $\mathrm{MeOH}(1.61 \mathrm{~mL}, 39.6$ $\mathrm{mmol})$ in DMF $(20 \mathrm{~mL})$ was degassed and then heated at $65^{\circ} \mathrm{C}$ under a $\mathrm{CO}$ atmosphere. After $24 \mathrm{~h}$, precipitates were removed by filtration and the filtrate was concentrated under reduced pressure. The residue was chromatographed $(5-10 \% \mathrm{MeOH}$ in $\left.\mathrm{CHCl}_{3}\right)$ to obtain $\mathbf{S 1 7}(0.32 \mathrm{~g}, 57 \%)$ as white crystalline solid.

${ }^{1}$ H NMR (DEUTERIUM OXIDE, 400MHz): $\boldsymbol{\delta}=8.90(\mathrm{~s}, 1 \mathrm{H}), 6.08(\mathrm{dd}, J=6.4,5.1 \mathrm{~Hz}, 1 \mathrm{H})$, 4.37 (q, $J=5.7 \mathrm{~Hz}, 1 \mathrm{H}), 4.02$ (q, $J=4.2 \mathrm{~Hz}, 1 \mathrm{H}), 3.82$ - 3.90 (m, $1 \mathrm{H}), 3.79$ (s, $3 \mathrm{H}), 3.66$ - 3.78 (m, $1 \mathrm{H}), 2.39$ - $2.52(\mathrm{~m}, 1 \mathrm{H}), 2.17$ - 2.32 (m, $1 \mathrm{H}) \mathrm{ppm}$. 


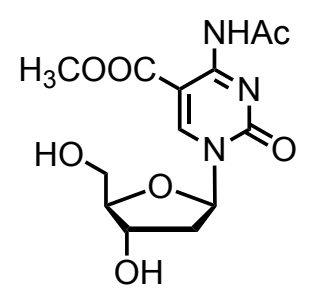

S18

To a stirring solution of $\mathbf{S 1 7}$ (0.32 g, $1.12 \mathrm{mmol}$, lequiv.) in anhydrous DMF $(3 \mathrm{~mL})$ was added $\mathrm{Ac}_{2} \mathrm{O}(0.159 \mathrm{~mL}, 1.68 \mathrm{mmol}, 1.5$ equiv.) The mixture was stirred at $\mathrm{rt}$ for $12 \mathrm{~h}$. TLC indicated complete conversion of starting material. The reaction was concentrated in vacuo. The residue was chromatographed (5$10 \% \mathrm{MeOH}$ in $\left.\mathrm{CHCl}_{3}\right)$ to obtain $\mathbf{S 1 8}(0.29 \mathrm{~g}, 79 \%)$ as white crystalline solid.

${ }^{1}$ H NMR (METHANOL-d 4 , 300MHz): $\boldsymbol{\delta}=9.40(\mathrm{~s}, 1 \mathrm{H}), 6.17$ (dd, $\left.J=6.3,5.2 \mathrm{~Hz}, 1 \mathrm{H}\right), 4.35$ 4.44 (m, 1 H), 4.00 - 4.07 (m, 1 H), 3.83 - 3.93 (m, 5 H), 3.73 - 3.81 (m, 1 H), 2.49 - 2.60 (m, 5 $\mathrm{H}), 2.22-2.35(\mathrm{~m}, 1 \mathrm{H}) \mathrm{ppm}$.

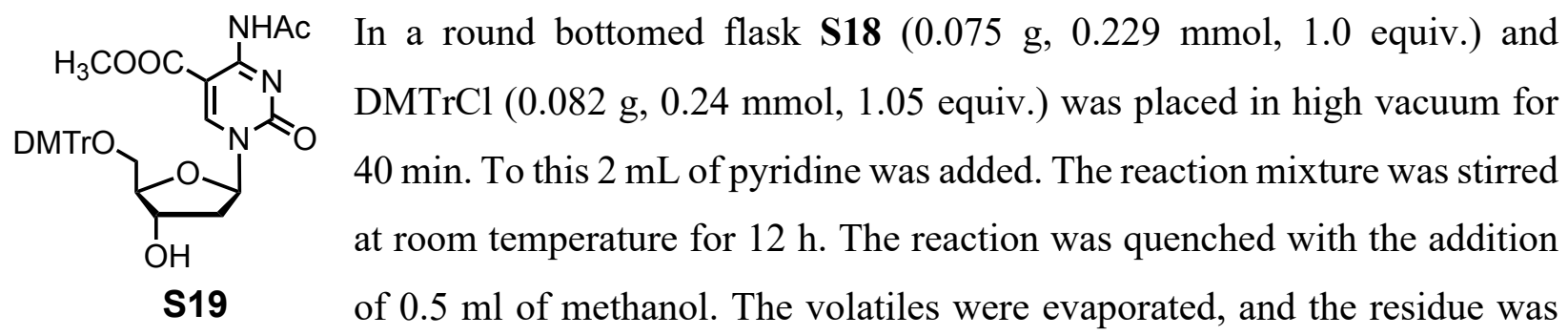
chromatographed $\left(\mathrm{CHCl}_{3}: \mathrm{MeOH} 99: 1\right.$ to $\left.95: 5\right)$ to obtain $\mathbf{S 1 9}(0.074 \mathrm{~g}, 51 \%)$ as solid crystalline material.

${ }^{1}$ H NMR (CHLOROFORM-d, 400MHz): $\boldsymbol{\delta}=10.82$ (s, $\left.1 \mathrm{H}\right), 9.10$ (s, $\left.1 \mathrm{H}\right), 7.37$ - 7.52 (m, $2 \mathrm{H}$ ), 7.20 - 7.34 (m, 7 H), 6.77 - 6.90 (m, 4 H), 6.28 (t, $J=6.1$ Hz, 1 H), 4.49 (br. s., 1 H), 4.15 - 4.29 (m, $1 \mathrm{H}), 3.79$ (d, $J=1.8 \mathrm{~Hz}, 6 \mathrm{H}), 3.64$ (dd, $J=10.9,2.8 \mathrm{~Hz}, 1 \mathrm{H}$ ), 3.36 (br. s., $1 \mathrm{H}$ ), 3.27 (dd, $J=10.8,2.9 \mathrm{~Hz}, 1 \mathrm{H}), 3.08$ (s, $3 \mathrm{H}), 2.75-2.87$ (m, 1 H), 2.63 (s, $3 \mathrm{H}), 2.26-2.40$ (m, $1 \mathrm{H}) \mathrm{ppm}$.

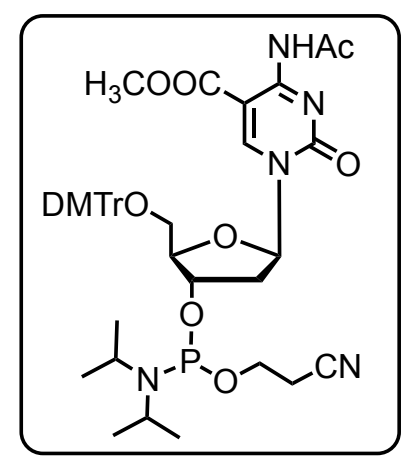

S3
To a solution of compounds S19 (0.074 g, $0.117 \mathrm{mmol}$, 1equiv.) and DIPEA (0.147 mL, $0.822 \mathrm{mmol}$, 7equiv.) in freshly distilled DCM (4 $\mathrm{mL}$ ) was added chlorophosphoramidite $(0.051 \mathrm{~mL}, 0.235 \mathrm{mmol}, 2$ equiv.) in dropwise fashion. The reaction mixture was stirred for $1.5 \mathrm{~h}$ and then concentrated in vacuo under inert atmosphere. The residue was chromatographed (30-50\% EtOAc in Hexanes $+0.1 \%$ pyridine) to obtain S3 (0.065 g, 66\%) as white foam. 
${ }^{1}$ H NMR (Acetone, 300MHz): $\boldsymbol{\delta}=10.68$ (br. s., $1 \mathrm{H}$ ), 9.08 (d, $\left.J=9.1 \mathrm{~Hz}, 1 \mathrm{H}\right), 7.47$ - 7.59 (m, 2 H), 7.22 - 7.41 (m, 8 H), 6.84 - 6.96 (m, 4 H), 6.18 (td, J=5.9, 3.6 Hz, 1 H), 4.56 - 4.73 (m, 1 H), 4.28 (dd, $J=13.2,3.8 \mathrm{~Hz}, 1 \mathrm{H}), 3.72-3.93$ (m, $7 \mathrm{H}$ ), 3.51 - 3.72 (m, 4 H), 3.34 (ddd, $J=10.9,6.4$, $3.5 \mathrm{~Hz}, 1 \mathrm{H}), 3.10$ (s, $3 \mathrm{H}), 2.63$ - $2.86(\mathrm{~m}, 3 \mathrm{H}), 2.41-2.63$ (m, 5 H), 1.09 - 1.20 (m, 9 H), 1.05 (d, $J=6.6 \mathrm{~Hz}, 3 \mathrm{H}) \mathrm{ppm}$.

HRMS m/z [M-H] ${ }^{-}$calcd. for $\mathrm{C}_{43} \mathrm{H}_{51} \mathrm{~N}_{5} \mathrm{O}_{10} \mathrm{P}: 828.3368$, found 828.3386 (2.1 ppm).

\section{Synthesis and purification of oligonucleotides}

DNA oligonucleotides (Table S5) carrying $5 \mathrm{mC}, 5 \mathrm{hmC}, 5 \mathrm{fC}$ and $5 \mathrm{caC}$, were synthesized using standard DNA phosphoramidite monomers (Glen Research) under ultra-mild conditions using 1Htetrazole as activator reagent in an Expedite Nucleic Acid Synthesis System (PerSeptive Biosystems) with DMT-ON protocol. To ensure good coupling elongated (4 min $30 \mathrm{sec}$ ) coupling times were applied for the coupling of modified bases and for standard bases ( $2 \mathrm{~min})$ normal coupling was applied. The crude deoxyoligonucleotide was cleaved from the beads and deprotected by incubating with ammonium hydroxide $(33 \% \mathrm{v} / \mathrm{v})$ at $25{ }^{\circ} \mathrm{C}$ for $24 \mathrm{hr}$. For $5 \mathrm{hmC}$ DNA, the deprotection step was heating at 75C for $24 \mathrm{hrs}$. A preliminary purification and DMT deprotection were carried out using Poly PakII purification cartridge (Glen Research, 60-3100-10) according to the standard protocol provided by the manufacturer and concentrated by SpeedVac concentrator followed by lyophilization, and re-dissolved in Nuclease free water. The quality and purity of synthesized DNA was monitored by high resolution MALDI-TOF-MS.

\section{Mutagenesis, expression, and purification of TET1 and 2 proteins}

Expression and purification of TET1 and 2 in E. coli. The catalytic domain of TET2 is comprised of a Cys-rich domain and a DS $\beta \mathrm{H}$ (also known as jelly-roll motif) domain with a large lowcomplexity insert. It has been reported by Yanhui Xu group that this unstructured insert poses significant challenge for crystallization. ${ }^{6}$ By screening a series of deletion mutants, Xu group found TET2 (1099-1936 with residues 1481-1843 replaced by a 15-residue GS-linker GGGGSGGGGSGGGGS) to be the minimum catalytically active fragment suitable for bacterial expression. A 6xHis tag was introduced at the $\mathrm{N}$-terminal for the purpose of initial purification. A similar deletion mutant was also generated for TET1 (1418- 2136 with residues 1755-1990 replaced by a 5 -residue GS-linker GSGGS). ${ }^{7}$ The above expression constructs were obtained from 
the $\mathrm{Xu}$ group at Fudan University. The plasmids were transformed into Escherichia coli strain BL21 star (DE3) competent cells (Invitrogen) using pET-28b kanamycin-resistant vector. ${ }^{8-9}$ A single colony was picked up and grown overnight at $37^{\circ} \mathrm{C}$ in $10 \mathrm{~mL}$ of Luria-Bertani (LB) broth in presence of $50 \mu \mathrm{g} / \mathrm{mL}$ kanamycin. The culture was diluted 100-fold and allowed to grow at 37 ${ }^{\circ} \mathrm{C}$ to an optical density (OD600) of 0.8 , and protein expression was induced overnight at $17{ }^{\circ} \mathrm{C}$ with $0.5 \mathrm{mM}$ IPTG in an Innova 44® Incubator shaker (New Brunswick Scientific). Proteins were purified as follows: harvested cells were resuspended in $15 \mathrm{~mL}$ lysis buffer $(50 \mathrm{mM}$ Tris- $\mathrm{HCl} \mathrm{pH}$ 8.0, $200 \mathrm{mM} \mathrm{NaCl}, 5 \mathrm{mM} \beta$-mercaptoethanol, 10\% glycerol, $25 \mathrm{mM}$ imidazole, Lysozyme, DNase, and Roche protease inhibitor cocktail). The cells were lysed by pulsed sonication (Qsonica-Q700) and centrifuged at $13,000 \mathrm{rpm}$ for $40 \mathrm{~min}$ at $4^{\circ} \mathrm{C}$. The soluble extracts were subjected to Ni-NTA agarose resin (Thermo) according to manufacturer's instructions. After passing 20 volumes of washing buffer (50 mM Tris-HCl pH 8.0, 200 mM NaCl, 5 mM $\beta$-mercaptoethanol, 10\% glycerol, and $25 \mathrm{mM}$ imidazole), proteins were eluted with a buffer containing $50 \mathrm{mM}$ Tris- $\mathrm{HCl} \mathrm{pH} 8.0$, $200 \mathrm{mM} \mathrm{NaCl}, 5 \mathrm{mM} \beta$-mercaptoethanol, 10\% glycerol, and $400 \mathrm{mM}$ imidazole. Proteins were further purified by gel filtration chromatography (Superdex-200) using AKTA pure FPLC system (GE healthcare) with buffer containing $50 \mathrm{mM}$ Tris-HCl pH 8.0, $150 \mathrm{mM} \mathrm{NaCl}$, and 10\% glycerol. Purified proteins were concentrated using Amicon Ultra-10k centrifugal filter device (Merck Millipore Ltd.). The protein concentration was determined using Bradford assay kit (BioRad Laboratories). The concentrated proteins were stored at $-80^{\circ} \mathrm{C}$ before use. TET1 and TET2 variants

reported in the current work were generated using the QuikChange Lightning site-directed mutagenesis kit (Agilent Technologies). The resulting mutant plasmids were confirmed by DNA sequencing. TET1 and TET2 mutants were expressed and purified as stated for the wild type protein.

\section{Relative quantification of $5 \mathrm{mC}$ and $5 \mathrm{mC}_{0 x}$ DNAs for standard curve}

For the standard curve, the percentage of $5 \mathrm{mC}, 5 \mathrm{hmC}, 5 \mathrm{fC}$ and $5 \mathrm{caC}$ containing synthetic DNAs was varied from 0 to 100 while keeping the total DNA concentration at $10 \mu \mathrm{M}$. After mixing, the samples were analyzed by MALDI-TOF mass spectrometry by spotting $1 \mu \mathrm{L}$ of sample and then mixed with $1 \mu \mathrm{L}$ of 3-Hydroxypicolinic Acid (3-HPA) matrix on a MALDI plate. The relative intensities of the synthesized DNAs were fitted to a straight line with nonlinear regression using GraphPad Prism. 


\section{In vitro TET demethylase assay}

For in vitro enzymatic activity assays, $10 \mu \mathrm{M}$ of double-stranded DNA substrate (5'-CAC5mCGGTG-3') was incubated with $10 \mu$ M TET2 (1099-1936 del-insert) and its mutants in buffer containing $50 \mathrm{mM}$ HEPES ( $\mathrm{pH} 8.0), 100 \mathrm{mM} \mathrm{NaCl}, 100 \mu \mathrm{M} \mathrm{Fe}\left(\mathrm{NH}_{4}\right)_{2}\left(\mathrm{SO}_{4}\right)_{2}, 2 \mathrm{mM}$ ascorbate, 1 $\mathrm{mM}$ DTT, $1 \mathrm{mM} \mathrm{ATP}$, and $1 \mathrm{mM}$ 2-KG. The samples were incubated for $3 \mathrm{~h}$ at $37^{\circ} \mathrm{C} .{ }^{10}$ Subsequently, the DNA was desalted by adding $8 \mu \mathrm{L}$ of $A G \circledR 50 \mathrm{~W}-\mathrm{X} 8$ Cation Exchange Resin (BioRad, Cat. \#143-5441) directly into the biochemical mixture and agitated followed by incubation for $5 \mathrm{~min}$ at room temperature. The samples were centrifuged at 10,000 rpm for $2 \mathrm{~min}$. The oxidized products were analyzed by MALDI-TOF mass spectrometry (AB SCIEX Voyager

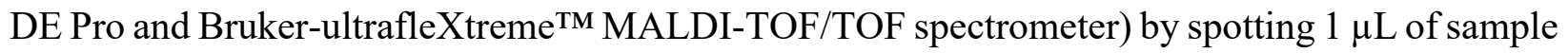
and then mixed with $1 \mu \mathrm{L}$ of 3-Hydroxypicolinic Acid (3-HPA) matrix on MALDI plate. Similarly, $20 \mu \mathrm{M}$ TET1 and its mutant were incubated with $10 \mu \mathrm{M}$ of double-stranded DNA substrate (5'CAC-5mCGGTG-3') in buffer containing $50 \mathrm{mM}$ HEPES (pH 8.0), $100 \mathrm{mM} \mathrm{NaCl}, 100 \mu \mathrm{M}$ $\mathrm{Fe}\left(\mathrm{NH}_{4}\right)_{2}\left(\mathrm{SO}_{4}\right)_{2}, 2 \mathrm{mM}$ ascorbate, $1 \mathrm{mM}$ DTT, $1 \mathrm{mM} \mathrm{ATP}$, and $1 \mathrm{mM} 2-\mathrm{KG}$, for $3 \mathrm{~h}$ at $37^{\circ} \mathrm{C}$. The products were desalted using cation-exchange resin method described above and were analyzed by MALDI-TOF mass spectrometry.

\section{Time-dependent TET demethylation assay using modified DNA substrates}

For in vitro time-dependent enzymatic activity assays, $10 \mu \mathrm{M}$ of double-stranded DNA substrate (5'-CAC-5XGGTG-3', $\mathrm{X}=5 \mathrm{mC}, 5 \mathrm{hmC}, 5 \mathrm{fC}$ ) was incubated with TET2 and its mutants (10991936 del-insert) (each $5 \mu \mathrm{M}$ ), TET1 and its mutants (each $20 \mu \mathrm{M}$ ) in buffer containing $50 \mathrm{mM}$ HEPES (pH 8.0), $100 \mathrm{mM} \mathrm{NaCl}, 100 \mu \mathrm{M} \mathrm{Fe}\left(\mathrm{NH}_{4}\right)_{2}\left(\mathrm{SO}_{4}\right)_{2}, 2 \mathrm{mM}$ ascorbate, $1 \mathrm{mM}$ DTT, $1 \mathrm{mM}$

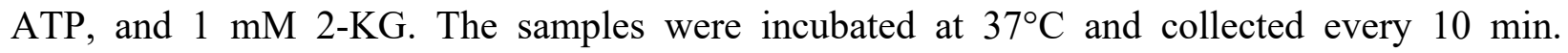
Subsequently, the products were desalted using cation-exchange resin method as described above and were analyzed by MALDI-TOF mass spectrometry.

For the measurement of kinetic parameters, $10 \mu \mathrm{M}$ of 8-nt double-stranded 5mC DNA substrate was incubated with TET2-V1395A mutant $(2 \mu \mathrm{M})$ with varied $2 \mathrm{KG}$ concentrations in a buffer containing $50 \mathrm{mM}$ HEPES (pH 8.0), $100 \mathrm{mM} \mathrm{NaCl}, 100 \mathrm{mM} \mathrm{Fe}\left(\mathrm{NH}_{4}\right)_{2}\left(\mathrm{SO}_{4}\right)_{2}, 2 \mathrm{mM}$ ascorbate, 1 $\mathrm{mM} \mathrm{DTT}$, and $1 \mathrm{mM} \mathrm{ATP}$ at $37^{\circ} \mathrm{C}$. The samples were collected at different time intervals ranging from 5 - 40 min. Samples were desalted using $A^{\circledR}{ }^{\circledR} 50 \mathrm{~W}-X 8$ Resin (BioRad, Cat \# 143-5441). The 
enzymatic products were analyzed through MALDI using 3-hydroxypicolinic acid (3-HPA) matrix. Only points within the linear range were used to calculate the slope for each $2 \mathrm{KG}$ concentration and the values were fitted to the Michaelis-Menten equation $v_{0}=\left(V_{\max }[S]\right) /\left(K_{\mathrm{m}}+[S]\right)$ to get the $K_{\mathrm{M}}$ and $k_{\text {cat }}$ values. Experiments were performed in triplicates.

\section{Acquisition and analysis of MALDI data}

The MALDI data were collected on AB SCIEX Voyager DE Pro MALDI-TOF and BrukerultrafleXtreme ${ }^{\mathrm{TM}}$ MALDI-TOF/TOF mass spectrometers. The experiments were conducted in reflectron negative TOF mode and the ion intensities were normalized to the highest peak. The background noise was corrected for calculating signal/noise ratios using AB Sciex Data Explorer (4.0) and the apex peak intensities were measured for quantitative analysis. For quantitative analysis of TET enzymatic activity, we included the intensities of $5 \mathrm{mC}$ (the substrate), $5 \mathrm{hmC}, 5 \mathrm{fC}$ and $5 \mathrm{caC}$ (the product) peaks. In all the TET-related MALDI spectra, peaks corresponding to substrate and products were clearly labeled. We showed that the MALDI-based measurement is suitable for providing quantitative information on TET enzymatic activity because of the similar ionization potentials of $5 \mathrm{mC}, 5 \mathrm{hmC}, 5 \mathrm{fC}$ and $5 \mathrm{caC}$ containing DNAs.

\section{Demethylase assay and bisulfite treatment on 76-mer dsDNA containing $5 \mathrm{mC}$} 4000 ng of double-stranded 76-mer DNA substrate (5'- CCT CAC CAT CTC AAC CAA TAT TAT ATT A TGT GTA TAC AC 5mC GGT GTT TGT GTT ATA ATA TTG AGG GAG AAG TGG TGA-3') was incubated with TET2 (1099-1936 del-insert) and its mutant V1395A TET2 in buffer containing $50 \mathrm{mM}$ HEPES ( $\mathrm{pH} 8.0$ ), $100 \mathrm{mM} \mathrm{NaCl}, 100 \mu \mathrm{M} \mathrm{Fe}\left(\mathrm{NH}_{4}\right)_{2}\left(\mathrm{SO}_{4}\right)_{2}, 2 \mathrm{mM}$ ascorbate, $1 \mathrm{mM}$ DTT, $1 \mathrm{mM}$ ATP, and $1 \mathrm{mM}$ 2-KG. The samples were incubated for $3 \mathrm{~h}$ at $37^{\circ} \mathrm{C}$. Subsequently, the DNA was purified with GeneJET PCR Purification Kit (Thermo Fisher, Cat. \#K0701) following the supplier's instructions. The concentration of these was samples was measured via UV Spectrometer and $1500 \mathrm{ng}$ of DNA was applied to EpiTect Bisulfite Kit (QIAGEN, Cat. \#59104) following the supplier's instructions. PCR amplification was carried out with Hot Start Taq polymerase (QIAGEN, Cat \#203207) (forward primer: 5'- CCC TTT TAT TAT TTT AAT TAA TAT TAT ATT-3'; reverse primer: 5'- CTC CGA CAT TAT CAC TAC CAT CAA CCA CCC ATC CTA CCT GGA CTA CAT TCT TAT TCA GTA TTC ACC ACT TCT CCC TCA AT- $3^{\prime}$ ). The PCR was performed in 2 steps with both primers in the PCR mixture. Hot 
Start Taq polymerase was activated for $15 \mathrm{~min}$ at $95^{\circ} \mathrm{C}$. Following activation, initial denaturation $\left(5 \mathrm{~min}\right.$ at $\left.94^{\circ} \mathrm{C}\right)$, denaturation $\left(1 \mathrm{~min}\right.$ at $\left.94^{\circ} \mathrm{C}\right)$, annealing (reverse primer, $1 \mathrm{~min}$ at $63^{\circ} \mathrm{C}$ ) and extension $\left(1 \mathrm{~min}\right.$ at $\left.72^{\circ} \mathrm{C}\right)$ were carried out. The final extension was carried out for $10 \mathrm{~min}$ at $72^{\circ} \mathrm{C}$. Without purification, the mixture was proceeded for another PCR round starting with Hot Start Taq polymerase activation $\left(15 \mathrm{~min}\right.$ at $\left.95^{\circ} \mathrm{C}\right)$. Following activation, initial denaturation ( $5 \mathrm{~min}$ at $94^{\circ} \mathrm{C}$ ), denaturation $\left(1 \mathrm{~min}\right.$ at $94^{\circ} \mathrm{C}$ ), annealing (forward primer, $1 \mathrm{~min}$ at $44^{\circ} \mathrm{C}$ ) and extension $(1$ min at $72^{\circ} \mathrm{C}$ ) were carried out. The final extension was carried out for $10 \mathrm{~min}$ at $72^{\circ} \mathrm{C}$. 30 cycles of PCR amplification were performed for each primer. The PCR reaction mix was run on a 1.5\% agarose gel, and a single band was extracted using GeneJET Gel Extraction Kit (Thermo Fisher, Cat. \#K0691) and sent for Sanger sequencing (sequencing primer: 5'-CCC TTT TAT TAT TTT AAT TAA TAT TAT ATT-3').

\section{Mammalian cell culture and genomic DNA isolation}

Human embryonic kidney (HEK) 293 T cells were grown in Dulbecco modified Eagle medium (DMEM) (Gibco) supplemented with 10\% fetal calf serum in a humidified atmosphere containing $5 \% \mathrm{CO}_{2}$ grown in a T25 flask for $24 \mathrm{~h}$. The cells were treated with $\sim 5 \mu \mathrm{g}$ of wild type or mutant TET2. The cells were harvested by trypsinization and resuspended in ice-cold $10 \mathrm{mM}$ phosphatebuffered saline (PBS) $\mathrm{pH} 7.2$, and genomic DNA (gDNA) was purified from $1 / 2$ flask of the collected cells using the DNeasy Blood \& Tissue Kit (Qiagen, Catalog \# 69504) following manufacturer's protocol. The extracted genomic DNA was subjected to dot-blot assay with 5hmC and $5 \mathrm{caC}$ antibody as described below.

\section{Activity of TET1-2 and their mutants on genomic DNA and dot-blot assay}

For in vitro time-dependent enzymatic activity assay on genomic DNA, $30 \mu \mathrm{g}$ genomic DNA was equally distributed among three tubes containing $25 \mathrm{uL}$ of assay buffer (50 mM HEPES ( $\mathrm{pH} 8.0$ ), $100 \mathrm{mM} \mathrm{NaCl}, 100 \mu \mathrm{M} \mathrm{Fe}\left(\mathrm{NH}_{4}\right)_{2}\left(\mathrm{SO}_{4}\right)_{2}, 2 \mathrm{mM}$ ascorbate, $1 \mathrm{mM}$ DTT, $1 \mathrm{mM}$ ATP, and $1 \mathrm{mM} 2-$ KG). 5 uM of TET2 (wild type or V1395A mutant) was added to the reaction mixture. Nuclease free water was added instead to the negative control (no enzyme). The samples were incubated at $37^{\circ} \mathrm{C}$ and $7 \mu \mathrm{L}$ of sample was collected every $30 \mathrm{~min}$. The final $7 \mu \mathrm{L}$ containing $2800 \mathrm{ng}$ of gDNA

was diluted with nuclease free water to make up the volume to $20 \mathrm{uL}$. To this was added $1 / 4$ volume of $2 \mathrm{M} \mathrm{NaOH}-50 \mathrm{mM}$ EDTA, followed by addition of 1:1 ice cold $2 \mathrm{M}$ ammonium acetate. 
Immobilin-P PVDF membranes (Merck Millipore Ltd. Catalog \# IPVH00010) were cut to size, wet with $\mathrm{MeOH}$ for $20 \mathrm{sec}$, and equilibrated in TE buffer for $5 \mathrm{~min}$, then assembled into a 96-well Bio-Dot microfiltration apparatus (Bio-Rad, Catalog \#1706545). Each well was washed with 400 $\mu 1 \mathrm{TE}$ drawn through with gentle vacuum. $400 \mathrm{ng}, 400 \mathrm{ng}, 800 \mathrm{ng}$ and $1000 \mathrm{ng}$ of gDNA was loaded for testing $5 \mathrm{mC}, 5 \mathrm{hmC}, 5 \mathrm{fC}$ and $5 \mathrm{caC}$ modification. Followed by another TE wash. Membranes were blocked for $2 \mathrm{~h}$ in 5\% milk-TBST, washed $3 \times$ with TBST, and blotted at $4{ }^{\circ} \mathrm{C}$ overnight with primary antibodies against each modified cytosine 1:1,000 rabbit anti-mC (RM231ab214727), 1:3,000 rabbit anti-hmC (RRID-AB_10013602) and 1:1,000 rabbit anti-fC (Active Motif, cat.no. 61227) and 1:3000 rabbit anti-5caC (ab231801). Blots were then washed, incubated with secondary 1:5,000 goat anti-rabbit-HRP (Active Motif, cat. no. 15015) for $2 \mathrm{~h}$. After similar washing, imaged by chemiluminescence using VISIGLO HRP Chemiluminescent substrates A and B (cat. no. N252-120ML and N253-120ML, aMReSCO) following manufacturer's protocol

For TET1, a $20 \mu \mathrm{L}$ demethylase assay containing $25 \mu \mathrm{M}$ TET1 (wild type or mutant), $3 \mu \mathrm{g}$ genomic DNA and $1 \mathrm{mM} 2-\mathrm{KG}$ was incubated at $37^{\circ} \mathrm{C}$ for $3 \mathrm{hr}$. in buffer containing $50 \mathrm{mM} \mathrm{HEPES}$ (pH 8.0), $100 \mathrm{mM} \mathrm{NaCl}, 100 \mu \mathrm{M} \mathrm{Fe}\left(\mathrm{NH}_{4}\right)_{2}\left(\mathrm{SO}_{4}\right)_{2}, 2 \mathrm{mM}$ ascorbate, $1 \mathrm{mM}$ DTT and $1 \mathrm{mM}$ ATP. Subsequently, the assay mixtures were loaded onto the PVDF membrane and analyzed using specific antibodies using the method described above.

\section{Biotin-labelling of $5 \mathrm{caC}$ in genomic DNA samples}

$6 \mu \mathrm{g}$ of genomic DNA was prepared by precipitating with $100 \%$ cold ethanol and $3 \mathrm{M}$ sodium

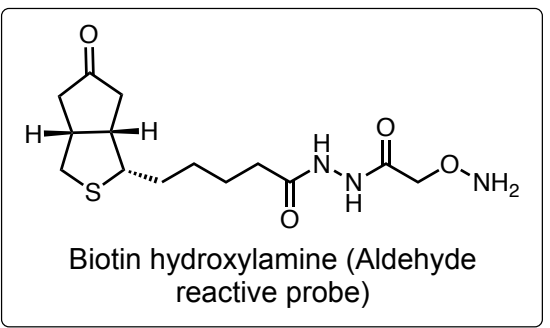
acetate $(\mathrm{pH}=5.2)$. The DNA was then purified using a cleanup kit and eluted in nuclease free water. A $20 \mu \mathrm{L}$ of demethylase assay containing $7.5 \mu \mathrm{M}$ TET2 and its mutant, purified genomic DNA and $1 \mathrm{mM} 2-\mathrm{KG}$ was incubated at 37 ${ }^{\circ} \mathrm{C}$ for $3 \mathrm{hr}$ in buffer containing $50 \mathrm{mM}$ HEPES (pH 8.0), 100 $\mathrm{mM} \mathrm{NaCl}, 100 \mu \mathrm{M} \mathrm{Fe}\left(\mathrm{NH}_{4}\right)_{2}\left(\mathrm{SO}_{4}\right)_{2}, 2 \mathrm{mM}$ ascorbate, $1 \mathrm{mM}$ DTT and $1 \mathrm{mM}$ ATP. sonicating genomic DNA extracted from HEK293T. A genome wide reduction was then performed with 50 $\mathrm{mM} \mathrm{NaBH}_{4}$ at $25{ }^{\circ} \mathrm{C}$ for $1.5 \mathrm{hr} .{ }^{11}$ The DNA was then purified using a clean-up kit and eluted in nuclease free water. The purified genomic DNA was incubated with $20 \mathrm{mM}$ NHS (Nhydroxysuccinimide and EDC (1-ethyl-3-(3-dimethylaminopropyl)carbodiimide 
hydrochloride) followed by incubation with $10 \mathrm{mM}$ O-(biotinylcarbazoylmethyl) hydroxylamine (Aldehyde-reactive probe (ARP), Cayman Chemical, Item \# 10009350, cas no. 627090-10-2) at $40{ }^{\circ} \mathrm{C}$ for $2 \mathrm{hr}^{12}$ Subsequently, the assay mixtures were loaded onto the PVDF membrane and analyzed using specific antibodies ${ }^{13}$ (Biotin antibody: PA1-26792 Invitrogen (Thermo Fisher), 1:1000 dilution; Secondary antibody: Donkey anti-goat $\mathrm{IgG}(\mathrm{H}+\mathrm{L}) \mathrm{pAb}$ (cat\# NBP1-74815, Novus) with 1:500 dilution) in the same method as described above.

\section{Overexpression of the catalytic domain of TET2 in HEK293T cells}

HEK293T cells were transfected with pCDNA vector carrying wild type or mutant human TET2 (catalytic domain) using Lipofectamine 2000 (Thermo) according to the manufacturer's protocol. ${ }^{8}$ The cells were harvested by trypsinization and, washed twice with ice-cold $10 \mathrm{mM}$ phosphatebuffered saline (PBS) $\mathrm{pH}$ 7.2. Pelleted cells were re-suspended in nuclei isolation buffer [NIB; 15 $\mathrm{mM}$ Tris- $\mathrm{HCl} \mathrm{pH}$ 7.5, $60 \mathrm{mM} \mathrm{KCl}, 15 \mathrm{mM} \mathrm{NaCl}, 5 \mathrm{mM} \mathrm{MgCl} 2,1 \mathrm{mM} \mathrm{CaCl}_{2}, 1 \mathrm{mM}$ dithiothreitol (DTT), $2 \mathrm{mM}$ sodium vanadate, $250 \mathrm{mM}$ sucrose, and $1 \mathrm{X}$ protease inhibitor mixture]. An equal volume of NIB buffer containing $0.6 \% \mathrm{NP}-40$ was added to the cells, the suspension was gently mixed and incubated on ice for $5 \mathrm{~min}$. Nuclei were pelleted by centrifugation at $2000 \mathrm{~g}$ for $5 \mathrm{~min}$ at $4^{\circ} \mathrm{C}$ and supernatant was discarded. The nuclei pellets were suspended in nuclei extraction buffer (NEB; 25 mM Tris- $\mathrm{HCl} \mathrm{pH}$ 8.0, $250 \mathrm{mM} \mathrm{NaCl}, 1 \mathrm{mM}$ EDTA, 10\% glycerol, 0.2\% NP-40, and $1 \mathrm{X}$ protease inhibitor mixture). Samples were sonicated for $5 \mathrm{~min}$ at amplitude of 100 with a repeating $1 \mathrm{~min}$ on and $20 \mathrm{sec}$ off pulse cycle and centrifuged at $2000 \mathrm{~g}$ for $5 \mathrm{~min}$ at $4^{\circ} \mathrm{C}$. The nuclear extracts were separated on a 4-12\% Criterion XT precast SDS-PAGE gel (Bio-Rad Laboratories) and analyzed for overexpression of TET2 enzyme by Western blotting as described below.

$75 \mu \mathrm{g}$ nuclear lysates were separated on 4-12\%-SDS-PAGE and transferred onto a $0.45 \mu \mathrm{m}$ supported nitrocellulose membrane (Bio-Rad Laboratories) at a constant current of $80 \mathrm{~V}$ for $1 \mathrm{~h}$ at $4^{\circ} \mathrm{C}$. Membranes were blocked with $5 \mathrm{~mL}$ of TBST buffer $(50 \mathrm{mM}$ Tris $\mathrm{HCl} \mathrm{pH}$ 7.4, $200 \mathrm{mM}$ $\mathrm{NaCl}, 0.01 \%$ Tween-20) with $5 \%$ nonfat dry milk for $1 \mathrm{hr}$ at room temperature with gentle shaking. The blocking buffer was then removed, and membranes were rinsed with $5 \mathrm{~mL}$ of TBST buffer. Immunoblotting was performed with 1:500 diluted primary antibody (FLAG-tag mAb, cat\# 14$6681-82$, Thermo) for overnight at $4{ }^{\circ} \mathrm{C}$. The antibody solutions were removed, and membranes 
were washed three times with TBST buffer. The blots were then incubated with HRP-conjugated secondary antibody Goat anti-Mouse IgG (cat\# 15014, Active motif) with 5\% nonfat dry milk (1:5000 dilution) in TBST for $1.5 \mathrm{~h}$ at room temperature. After similar washing, protein bands were visualized by chemiluminescence using VISIGLO HRP Chemiluminescent substrates A and B (cat\# N252-120ML and N253-120ML, aMReSCO) following manufacturer's protocol.

\section{Analysis of expression of DACT1 in HEK293T cells overexpressed with TET2}

HEK293T cells were transfected with pcDNA vector carrying wild type or mutant human TET2 (catalytic domain) using Lipofectamine 2000 (Thermo) according to the manufacturer's protocol. After 96 hr. post transfection, cells were washed with PBS and harvested by trypsinization and lysed with $150 \mu \mathrm{L}$ of cold RIPA buffer (Sigma) supplemented with 1X Roche protease inhibitor cocktail and $5 \mathrm{mM}$ TCEP by sonicating for $5 \mathrm{~min}$ at amplitude of 100 with a repeating 1 min on and $20 \mathrm{sec}$ off pulse cycle. Cell lysates were centrifuged at $15000 \mathrm{rpm}$ for $30 \mathrm{~min}$ at $4{ }^{\circ} \mathrm{C}$ to remove cell debris. The supernatant was collected, and protein concentration was determined by Bradford assay (Bio-Rad Laboratories). The cell lysates were separated on a 4-12\% Criterion XT precast SDS-PAGE gel (Bio-Rad Laboratories) and analyzed for overexpression of DACT1. ${ }^{14}$ The samples were subjected to $4-12 \%$ SDS-PAGE to separate the protein and transferred onto a 0.45 $\mu \mathrm{m}$ supported PVDF membrane (Bio-Rad Laboratories) at a constant current of $67 \mathrm{~mA}$ for $16 \mathrm{~h}$ at $4{ }^{\circ} \mathrm{C}$. Immunoblotting was performed overnight at $4{ }^{\circ} \mathrm{C}$ using anti-rabbit DACT1 antibody (1:200, cat\# PA5-114208, Thermo Fisher). The antibody solutions were removed, and membranes were washed three times with TBST buffer. The blots were then incubated with HRP-conjugated secondary antibodies Goat anti-rabbit-HRP (Active Motif, cat\# ab214728) with 5\% nonfat dry milk (1:5000 dilution) in TBST for $1.5 \mathrm{~h}$ at room temperature. After similar washing, protein bands were visualized by chemiluminescence using VISIGLO HRP Chemiluminescent substrates A and B (cat\# N252-120ML and N253- 120ML, aMReSCO) following manufacturer's protocol.

\section{DNA Immunoprecipitation (DIP)}

DNA immunoprecipitation was carried out based on published method. ${ }^{15}$ Genomic DNA from TET2 transfected HEK293T cells was isolated using Qiagen DNeasy Blood \& Tissue Kits. $6.5 \mu \mathrm{g}$

of isolated DNA was sonicated using Qsonica 700 cup-horn sonicator for $5 \mathrm{~min}$, to obtain a 
uniform fragment size of $200-500 \mathrm{bp}$. The DNA was then heat denatured at $95{ }^{\circ} \mathrm{C}$ for $10 \mathrm{~min}$ and rapidly cooled on ice for $5 \mathrm{~min} .2 \%$ sample was kept aside as input signal and remaining DNA was suspended in 10X IP buffer (10 mM sodium phosphate(monobasic), $1 \% \mathrm{NaCl}, 0.05 \%$ Triton $\mathrm{X}-100, \mathrm{pH}$ 7.0). IP was carried out overnight with $6.5 \mu \mathrm{g}$ of anti-5caC (Abcam - ab231801); and anti-5hmC (RRID - AB_10013602) at $4{ }^{\circ} \mathrm{C}$ with constant rotation. $30 \mu \mathrm{L}$ Protein $\mathrm{G}$ beads (Invitrogen) was washed 2 times with 10X IP buffer and incubated with the IP mixture for $2 \mathrm{hr}$ at $4{ }^{\circ} \mathrm{C}$ with constant rotation. Beads were washed with cold 10X IP buffer 3 times for 10 min each and then incubated with $50 \mathrm{mM}$ Tris $\mathrm{HCl}, 10 \mathrm{mM}$ EDTA, 1.0\% SDS, $50 \mathrm{mM} \mathrm{NaHCO}_{3}, 20 \mathrm{U}$ of proteinase $\mathrm{K}$ for $3 \mathrm{~h}$ at $55^{\circ} \mathrm{C}, 800 \mathrm{rpm}$. Eluted DNA was purified using QIAquick PCR Purification Kit. Quantitative PCR was performed with SYBR green master mix using qPCR primers ${ }^{14,16-17}$ as mention in Table S6.

\section{Genomic variation analysis of human TET1-3}

The genomic coordinate of the variant V1685A (chr10:68,686,357 T>C) in TET1, V1395A (chr4:105272565T $>$ C) in TET2 and V1090A (chr2:74,099,277 T $>$ C) in TET3 was found using UCSC human genome browser. ${ }^{18}$ Chosen the dbSNP and 1000 genome project variation annotations as additional tracks to show the variation in the region of interest. Which was then submitted to ANNOVAR (https://wannovar.wglab.org), TET1-Query: (“10 6868635768686357 T C”), TET2-Query: (“4 105272565105272565 T C”), and TET3-Query: (“2 7409927774099277 $\mathrm{T}$ C") by changing the default reference genome to hg38. The results from wANNOVAR were downloaded to retrieve allelic frequency information (Figure S15, Table S1). 


\section{Supplementary Figures and Tables}

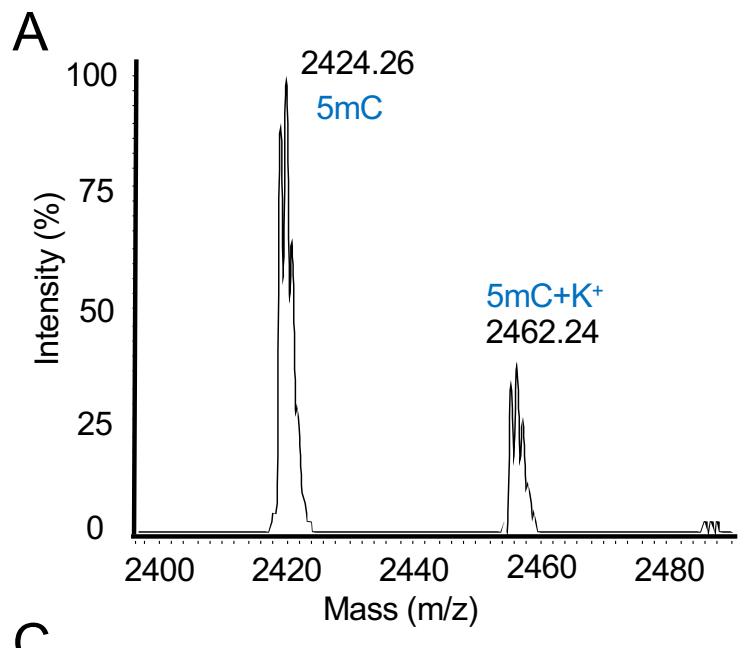

B
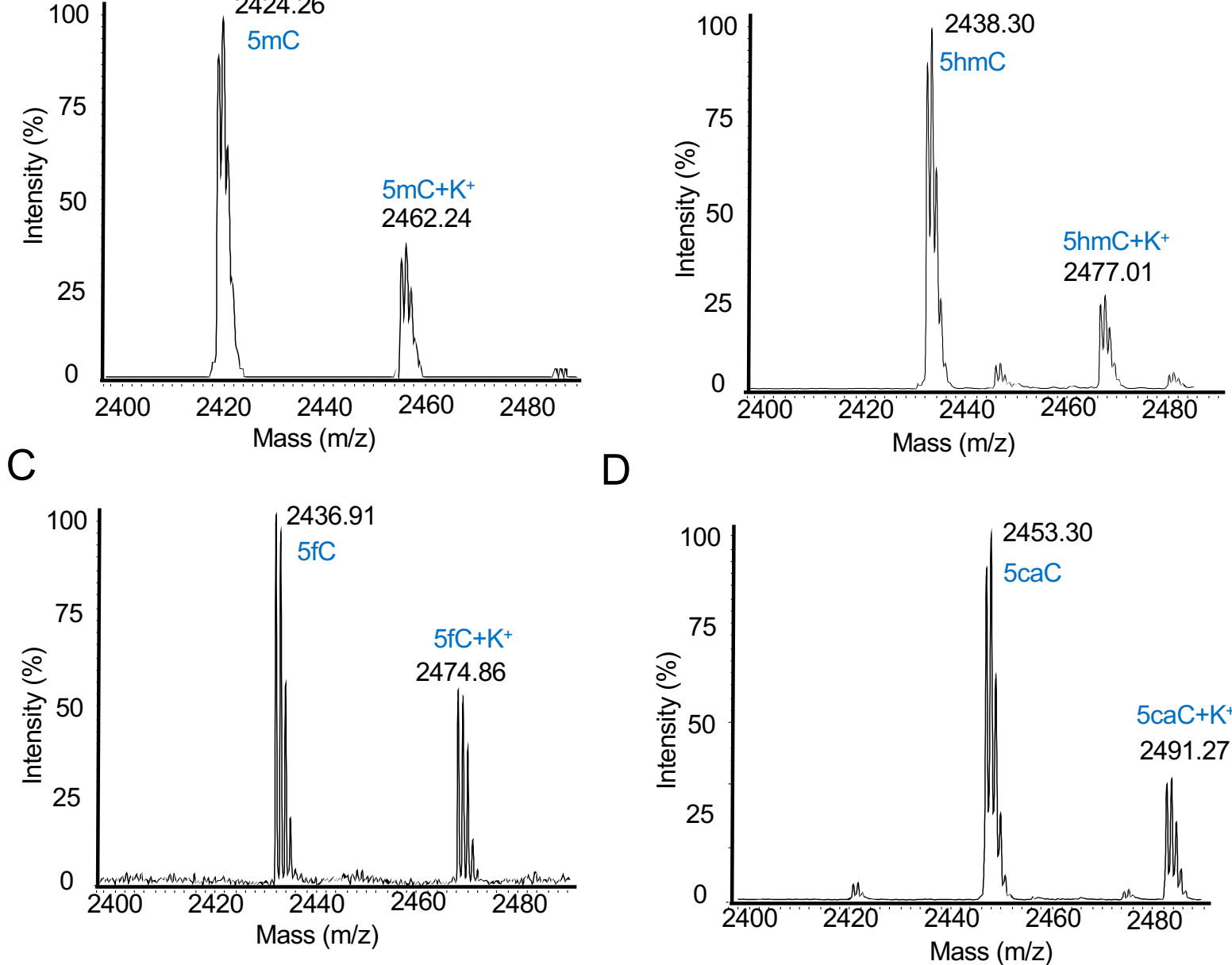

D

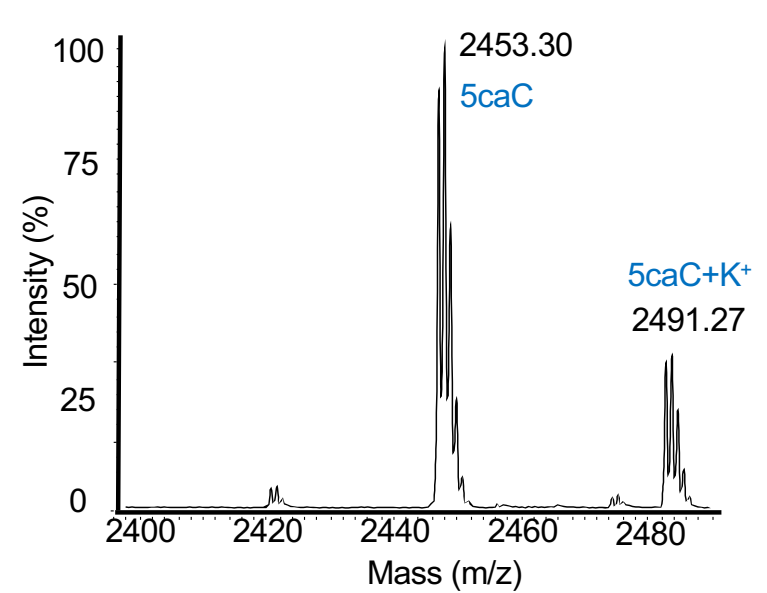

Supplementary Figure S1: (A-D) MALDI-MS spectra of synthetized 8-nucleotide DNAs CACXGGTG containing $X=5 \mathrm{mC}(\mathrm{A}), \mathrm{X}=5 \mathrm{hmC}(\mathrm{B}), \mathrm{X}=5 \mathrm{fC}(\mathrm{C})$ and $\mathrm{X}=5 \mathrm{caC}(\mathrm{D})$. 


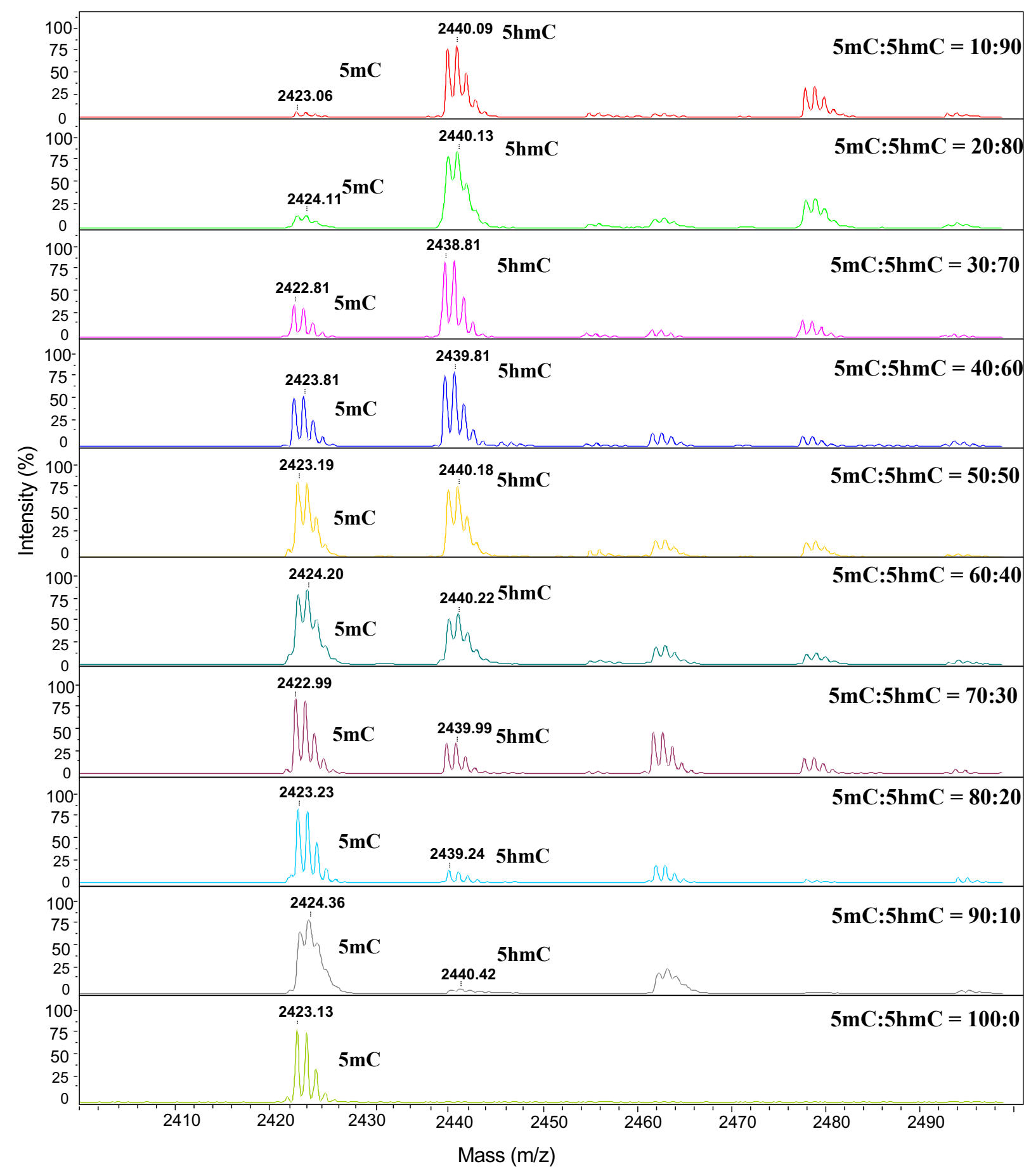

Supplementary Figure S2: MALDI-MS spectra of synthetized 8-nucleotide DNAs containing 5mC (CAC5mCGGTG) and 5hmC (CAC5hmCGGTG) in different experimental ratios. 


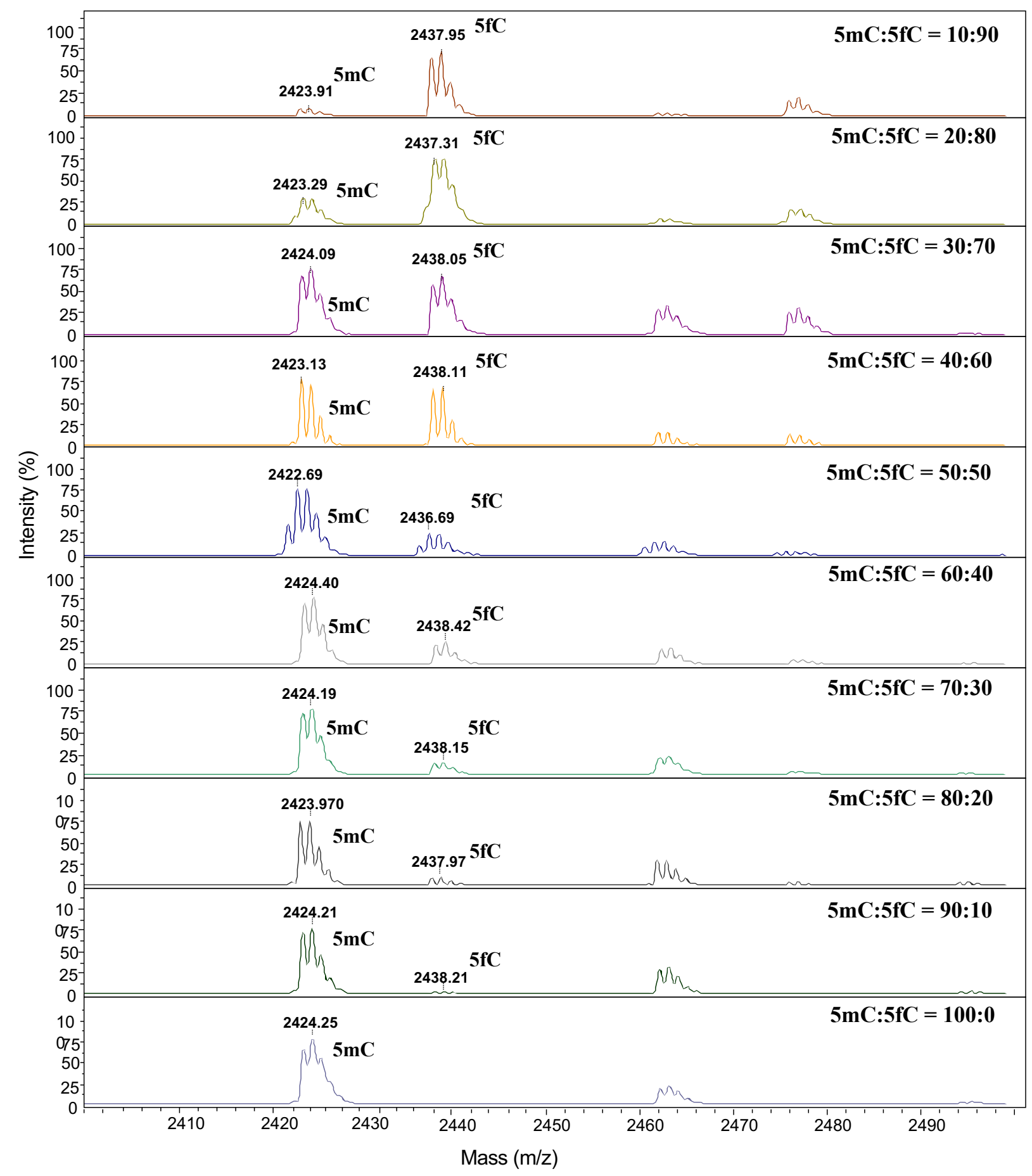

Supplementary Figure S3: MALDI-MS spectra of synthetized 8-nucleotide DNAs containing 5mC (CAC5mCGGTG) and 5fC (CAC5fCGGTG) in different experimental ratios. 


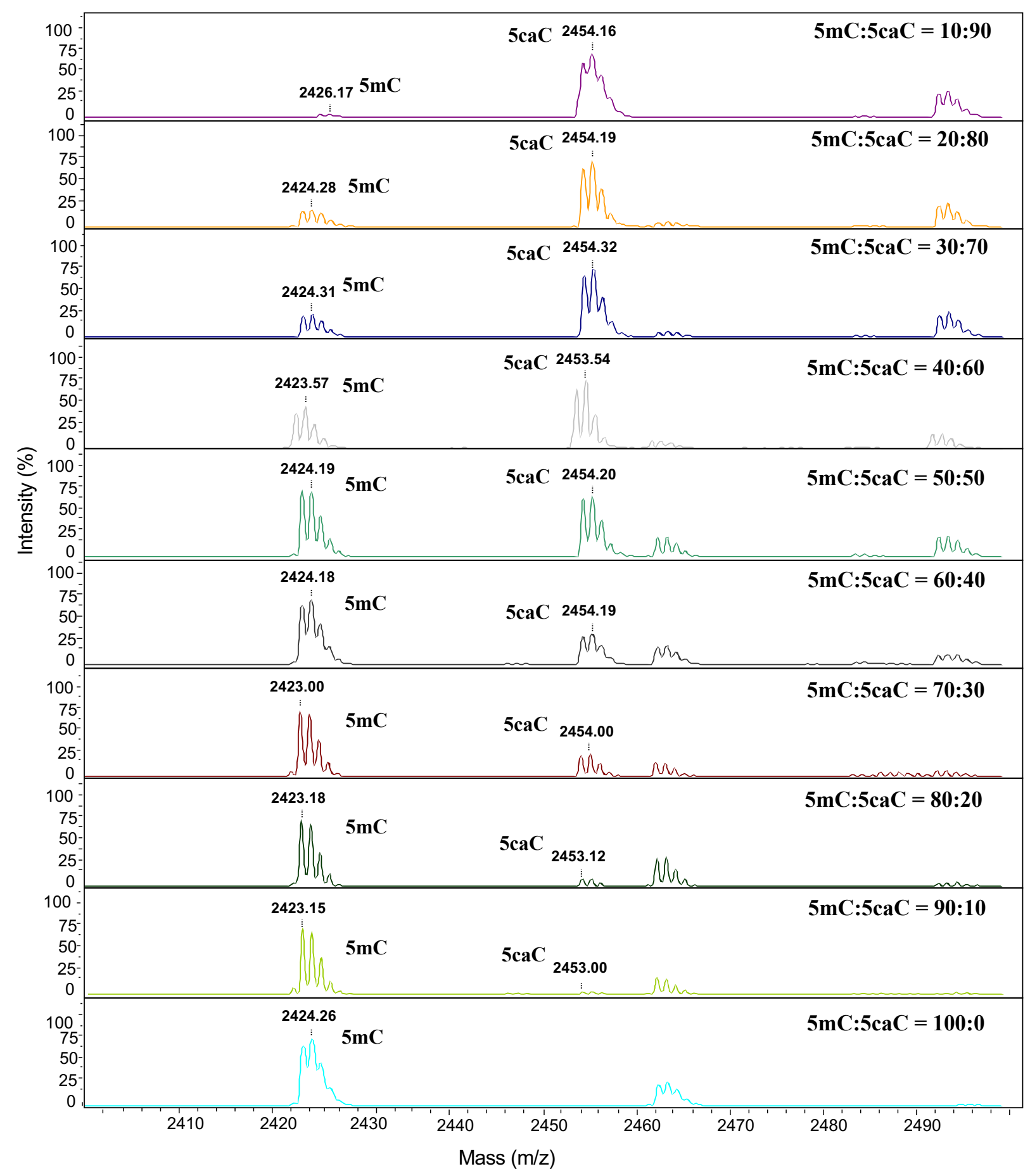

Supplementary Figure S4: MALDI-MS spectra of synthetized 8-nucleotide DNAs containing 5mC (CAC5mCGGTG) and 5caC (CAC5caCGGTG) in different experimental ratios. 

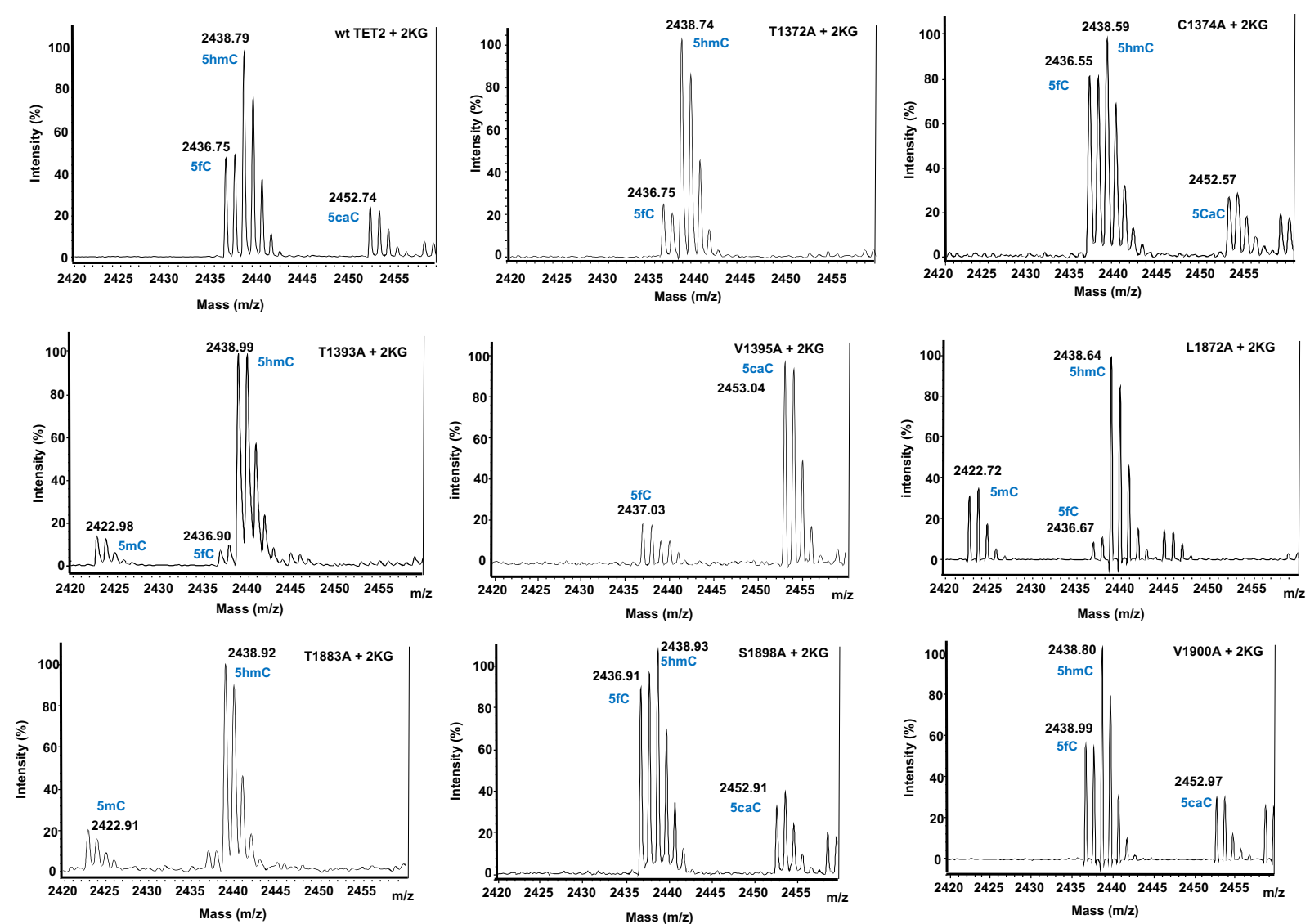

Supplementary Figure S5: MALDI-MS spectra showing \% intensity of wildtype TET2 and the mutants towards 5mC-containing 8-nt DNA substrate (CAC5mCGGTG) using cofactor 2KG. 


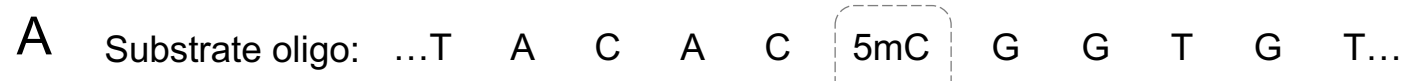

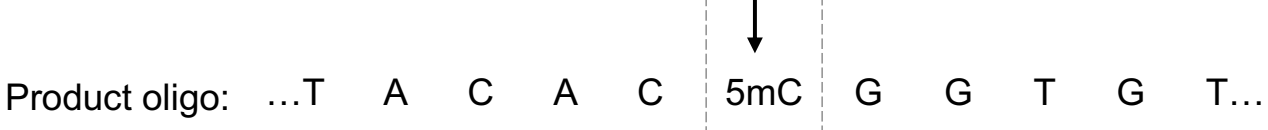

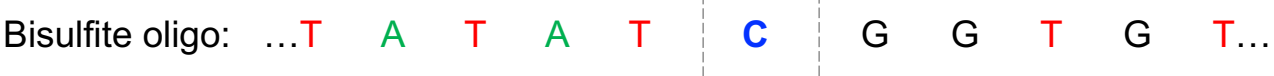

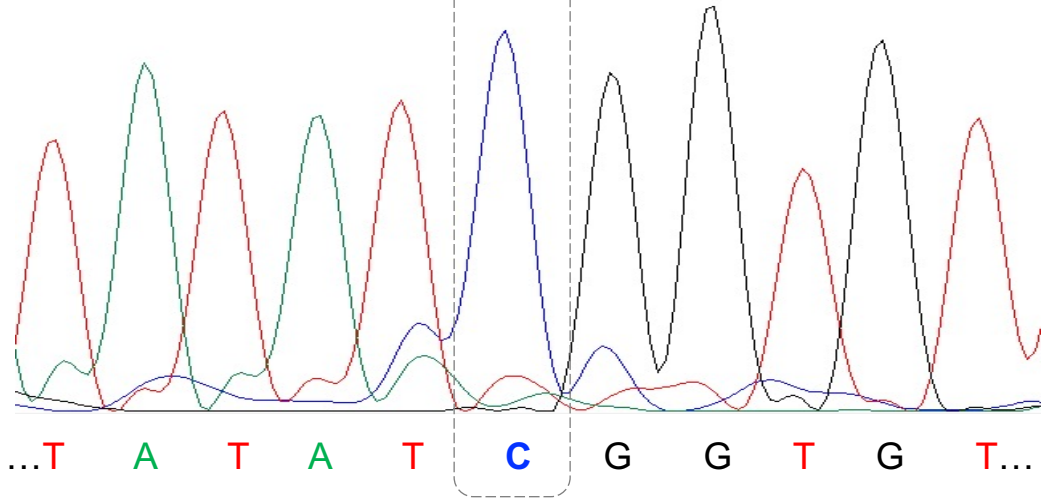

$\begin{array}{lllllllllllllll}\text { B } & \text { Substrate oligo: } & \ldots & \text { T } & \text { A } & \text { C } & \text { A } & \text { C } & 5 \mathrm{mC} & \mathrm{G} & \mathrm{G} & \mathrm{T} & \mathrm{G} & \mathrm{T} \ldots\end{array}$ $\begin{array}{lllllllllllll}\text { Product oligo: } & \ldots & \text { T } & \text { A } & \text { C } & \text { A } & \text { C } & 5 \mathrm{hmC} & \text { G } & \text { G } & \text { T } & \text { G } & \text { T... }\end{array}$

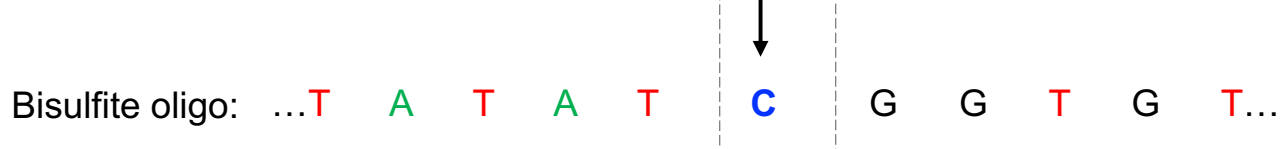

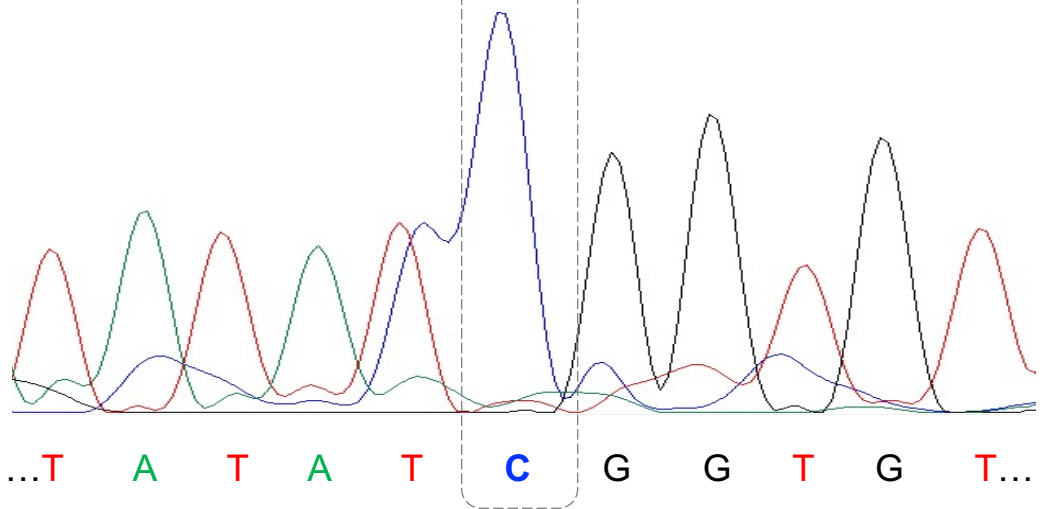

Supplementary Figure S6: Analysis of $5 \mathrm{mC}_{\mathrm{ox}}$ using bisulfite treatment and Sanger sequencing. A 76-mer dsDNA substrate carrying $5 \mathrm{mC}$ was subjected to no TET2 (A) and wild type TET2 (B) followed by bisulfite treatment, PCR amplification and Sanger sequencing. No $\mathrm{C}$ to $\mathrm{T}$ transition was observed for the wild type TET2 which indicates primarily $5 \mathrm{hmC}$ formation which is read as $\mathrm{C}$ in Sanger sequencing. 


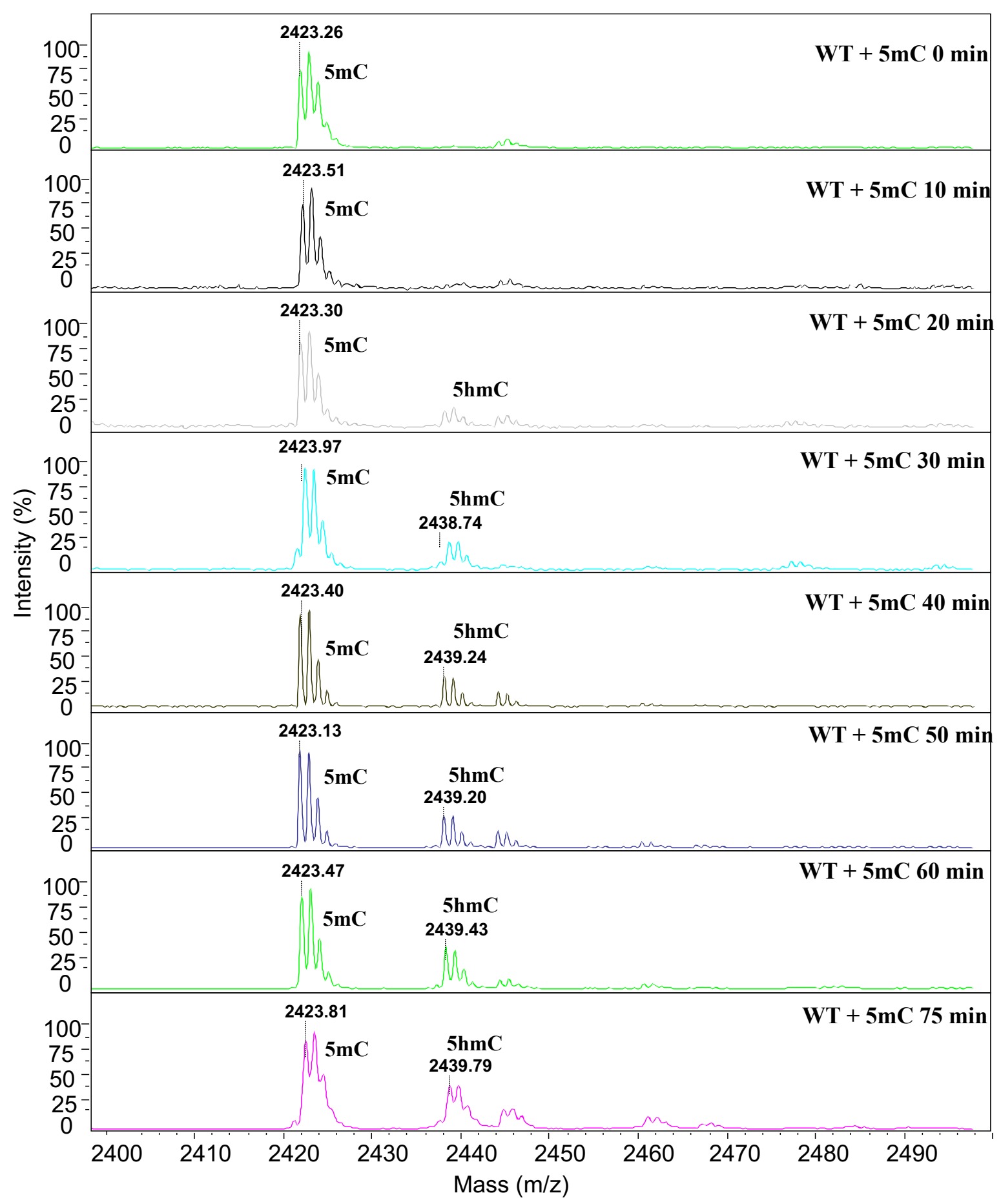

Supplementary Figure S7: MALDI-MS spectra showing time-dependent activity of wild type TET2 towards 5mC-containing 8-nt DNA substrate (CAC5mCGGTG) using cofactor 2KG. 


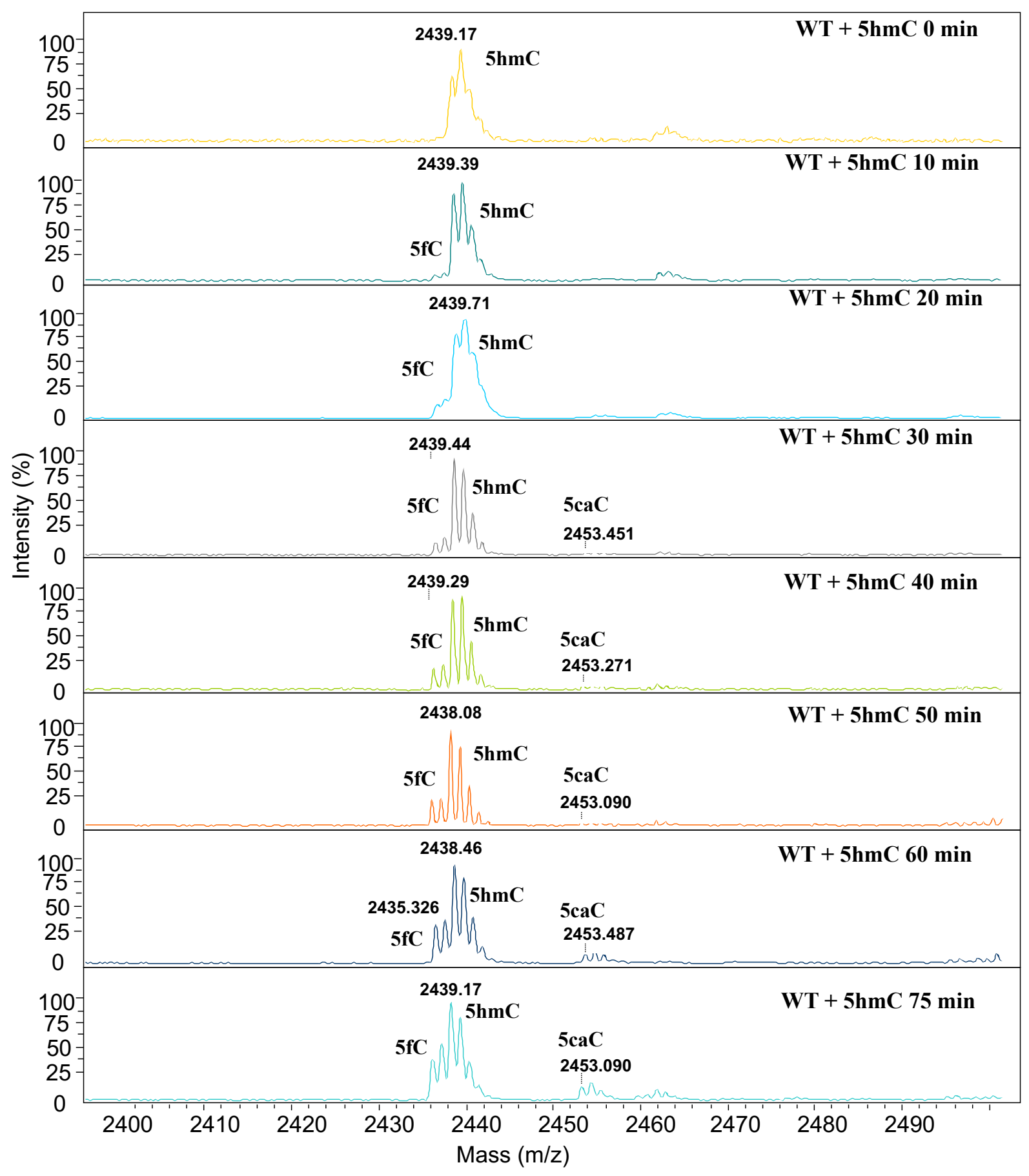

Supplementary Figure S8: MALDI-MS spectra showing time-dependent activity of wild type TET2 towards 5hmC-containing 8-nt DNA substrate (CAC5hmCGGTG) using cofactor 2KG. 


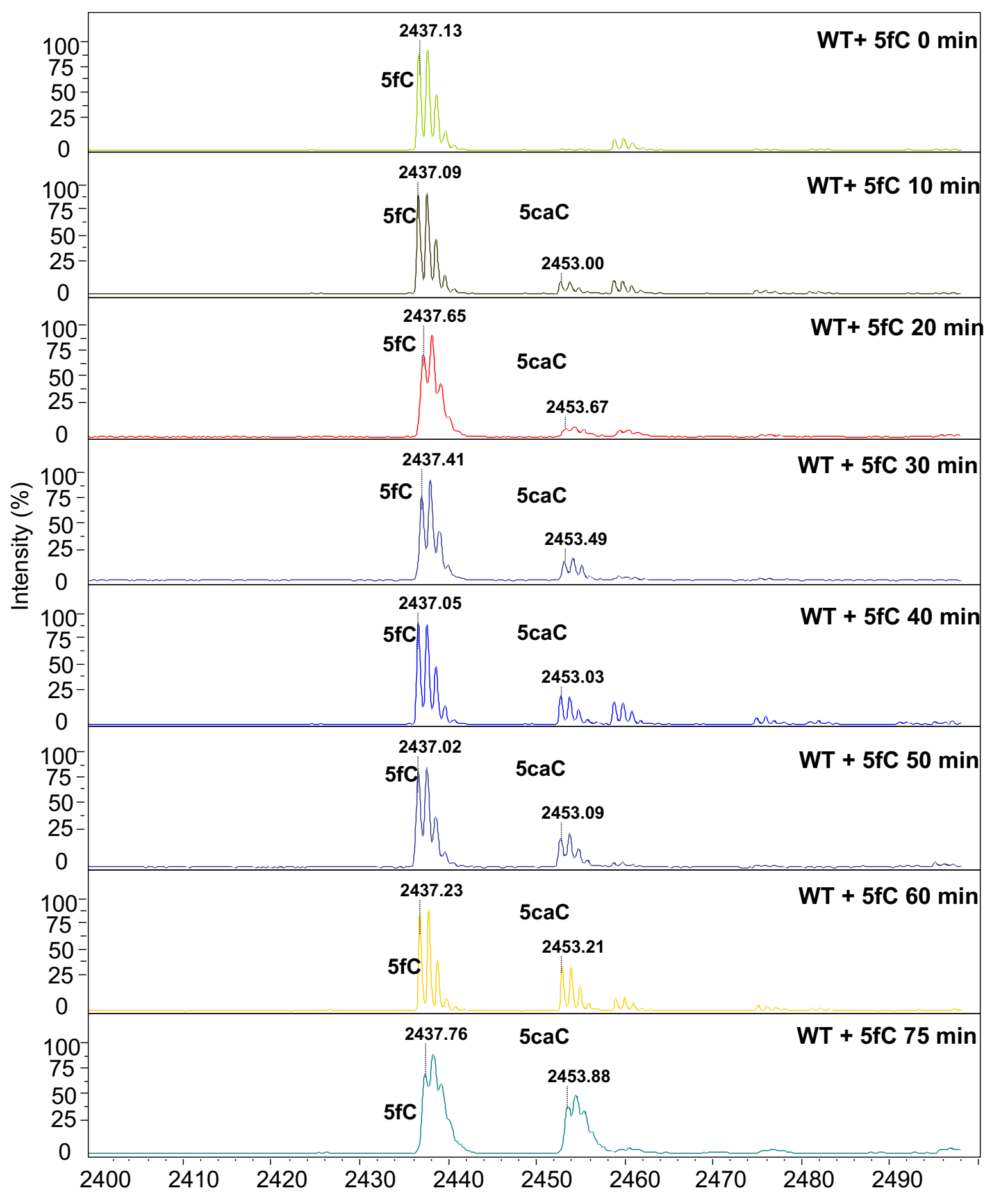

Supplementary Figure S9: MALDI-MS spectra showing time-dependent activity of wild type TET2 towards 5fC-containing 8-nt DNA substrate (CAC5fCGGTG) using cofactor 2KG. 


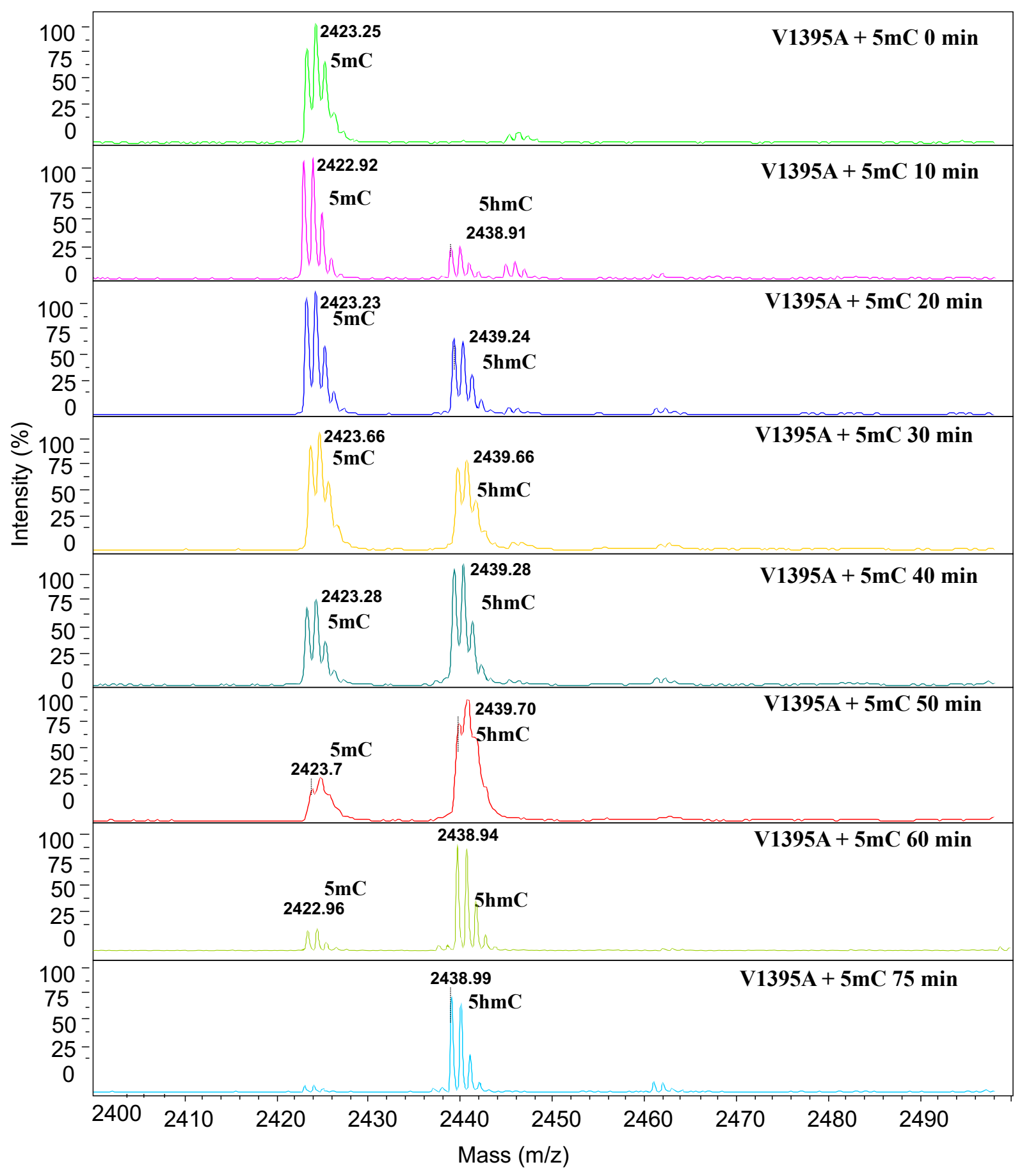

Supplementary Figure S10: MALDI-MS spectra showing time-dependent activity of V1395A mutant towards 5mC-containing 8-nt DNA substrate (CAC5mCGGTG) using cofactor 2KG. 


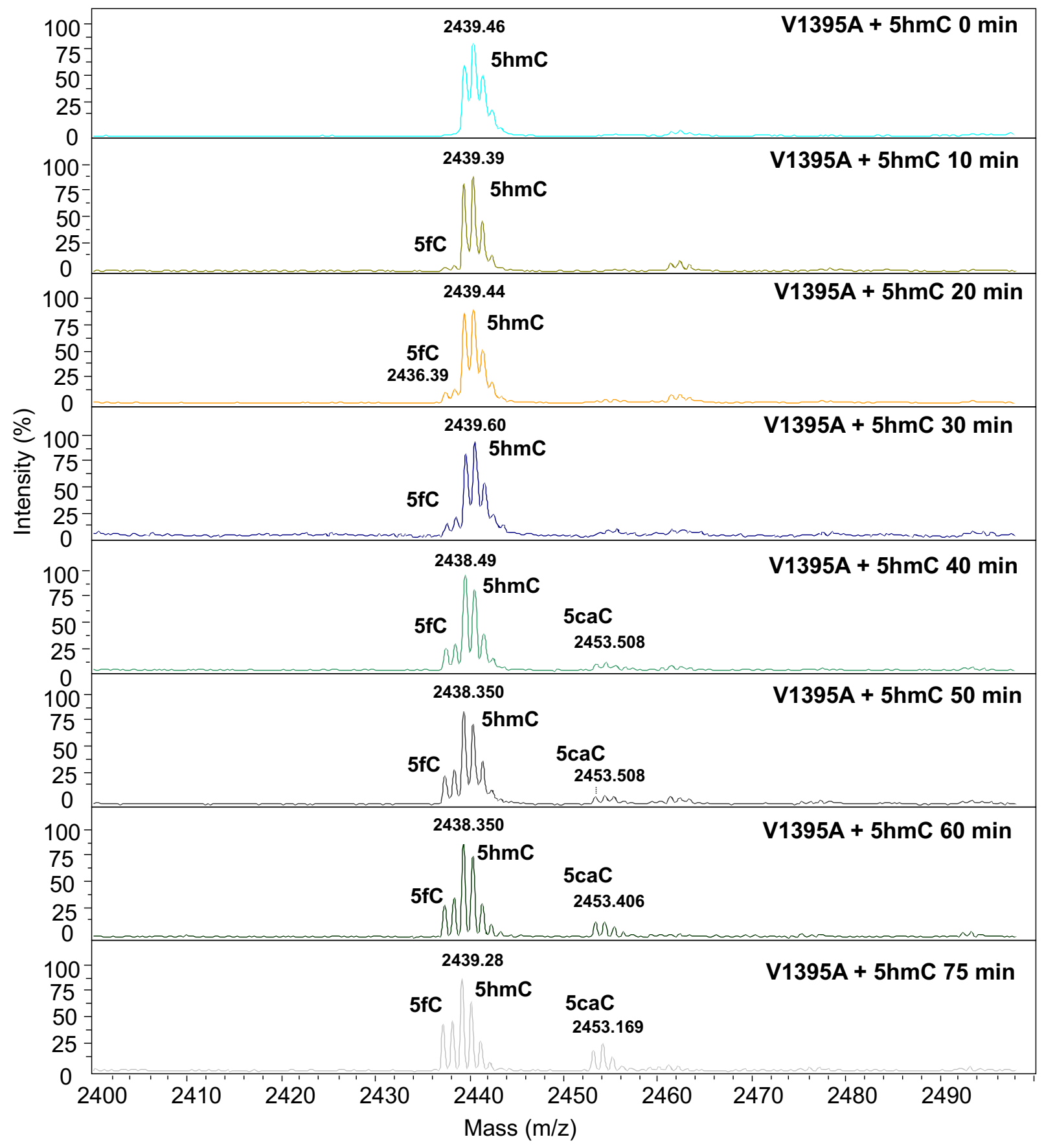

Supplementary Figure S11: MALDI-MS spectra showing time-dependent activity of V1395A mutant towards 5hmC-containing 8-nt DNA substrate (CAC5hmCGGTG) using cofactor 2KG. 


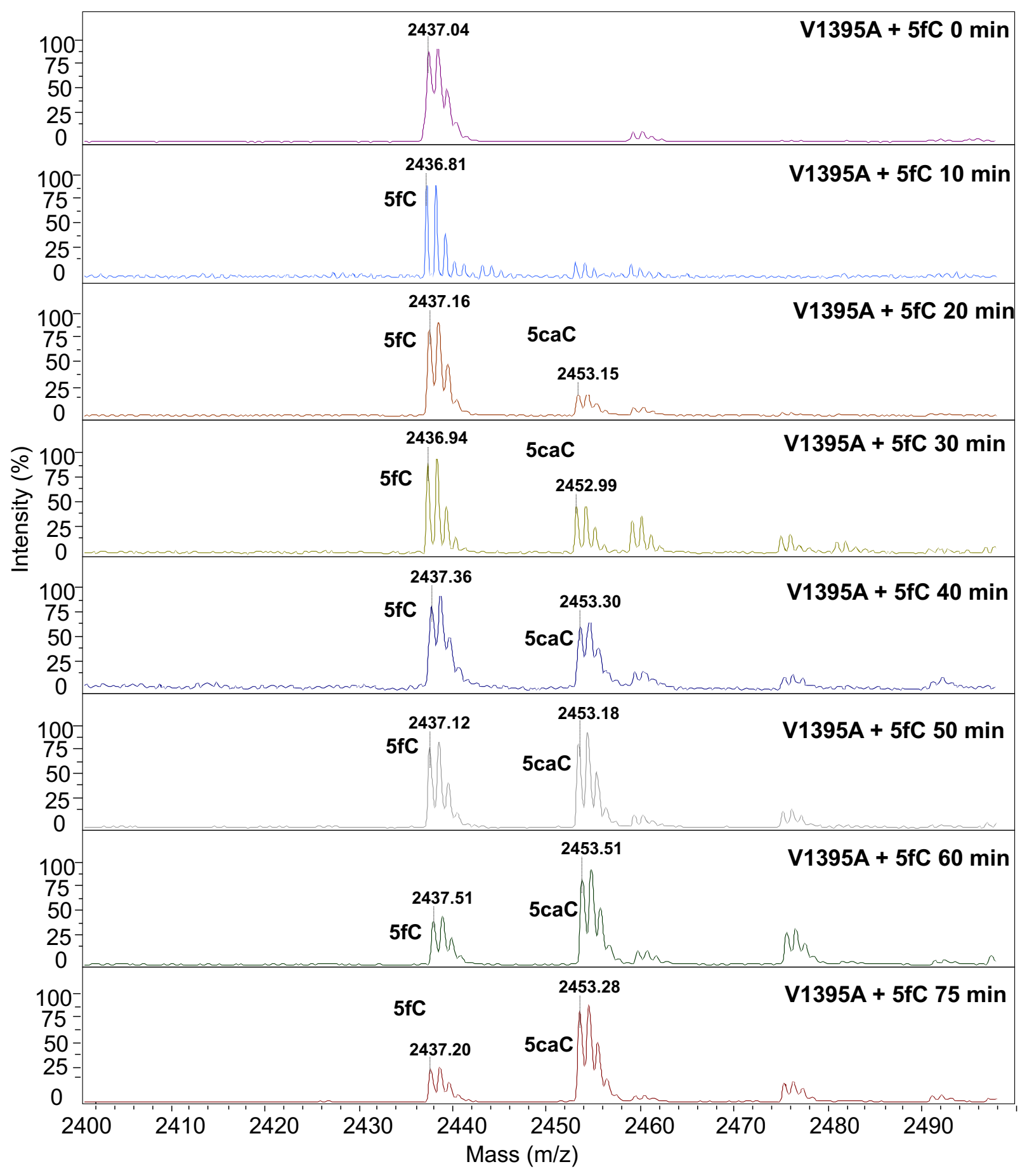

Supplementary Figure S12: MALDI-MS spectra showing time-dependent activity of V1395A mutant towards 5fC-containing 8-nt DNA substrate (CAC5fCGGTG) using cofactor 2KG. 

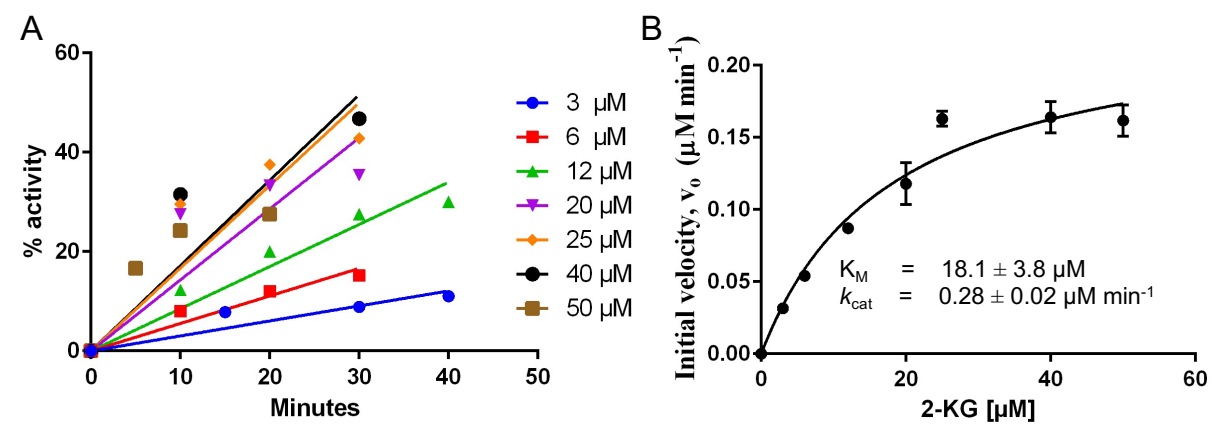

C

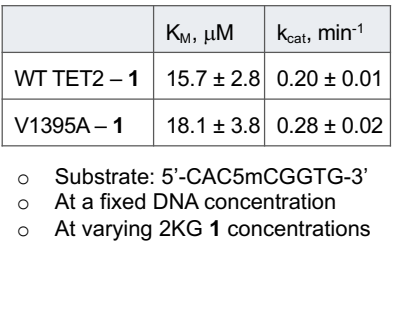

Supplementary Figure S13: Measurement of Michaelis-Menten parameters for TET2-V1395A$2 \mathrm{KG}$ pair. (A) Dose- and time-response activity of $2 \mathrm{KG}$ towards V1395A mutant based on MALDI-TOF MS analysis. Only points within the linear range were used to calculate the slope for each $2 \mathrm{KG}$ concentrations. (B) $K_{\mathrm{M}}$ and $k_{\text {cat }}$ values of V1395A-2KG pair were obtained by fitting the slopes to the Michaelis-Menten equation $v_{0}=\left(V_{\max }[S]\right) /\left(K_{\mathrm{m}}+[S]\right)$. (C) Table showing the kinetic parameters of wild type TET2 and V1395A mutant. $K_{\mathrm{M}}$ and $k_{\text {cat }}$ values of wild type TET2-2KG pair obtained using a similar method are reported in Ref. 10.
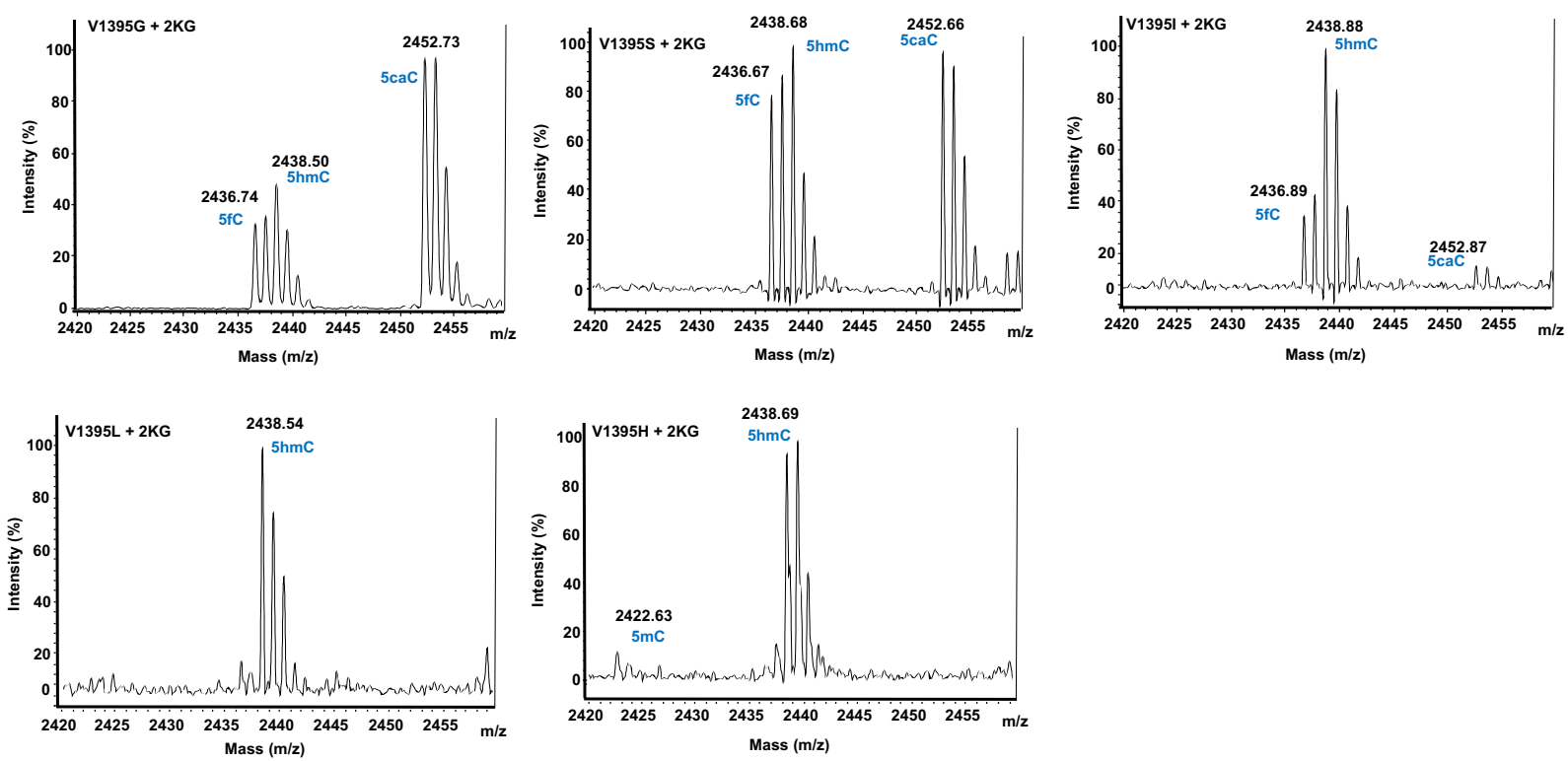

Supplementary Figure S14: MALDI-MS spectra showing activity of V1395G, V1395S, V1395I, V1395L and V1395H mutants towards 5mC-containing 8-nt DNA substrate (CAC5mCGGTG) using cofactor $2 \mathrm{KG}$. 

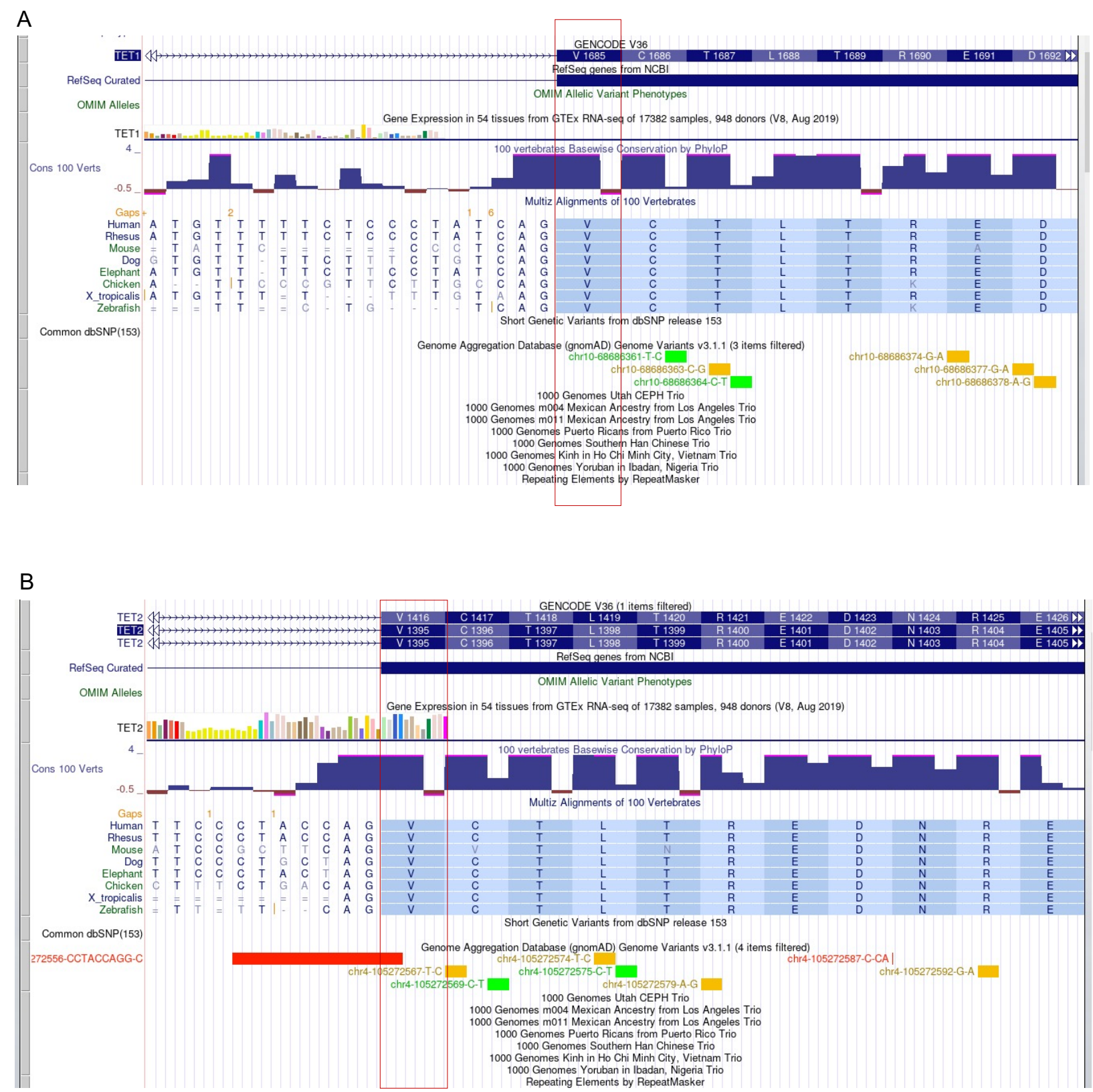

Supplementary Figure S15: (A) Genomic variation analysis of TET1 V1685A (chr10:68,686,357 T>C). ANNOVAR (https://wannovar.wglab.org; Query: “10 6868635768686357 T C”). No SNPs were found in the region of interest (TET1-V1685A). (B) Genomic variation analysis of TET2 V1395A (chr4:105272565T>C). ANNOVAR (https://wannovar.wglab.org; Query: “4 105272565 105272565 T C"). No SNPs were found in the region of interest (TET2 V1395A). 


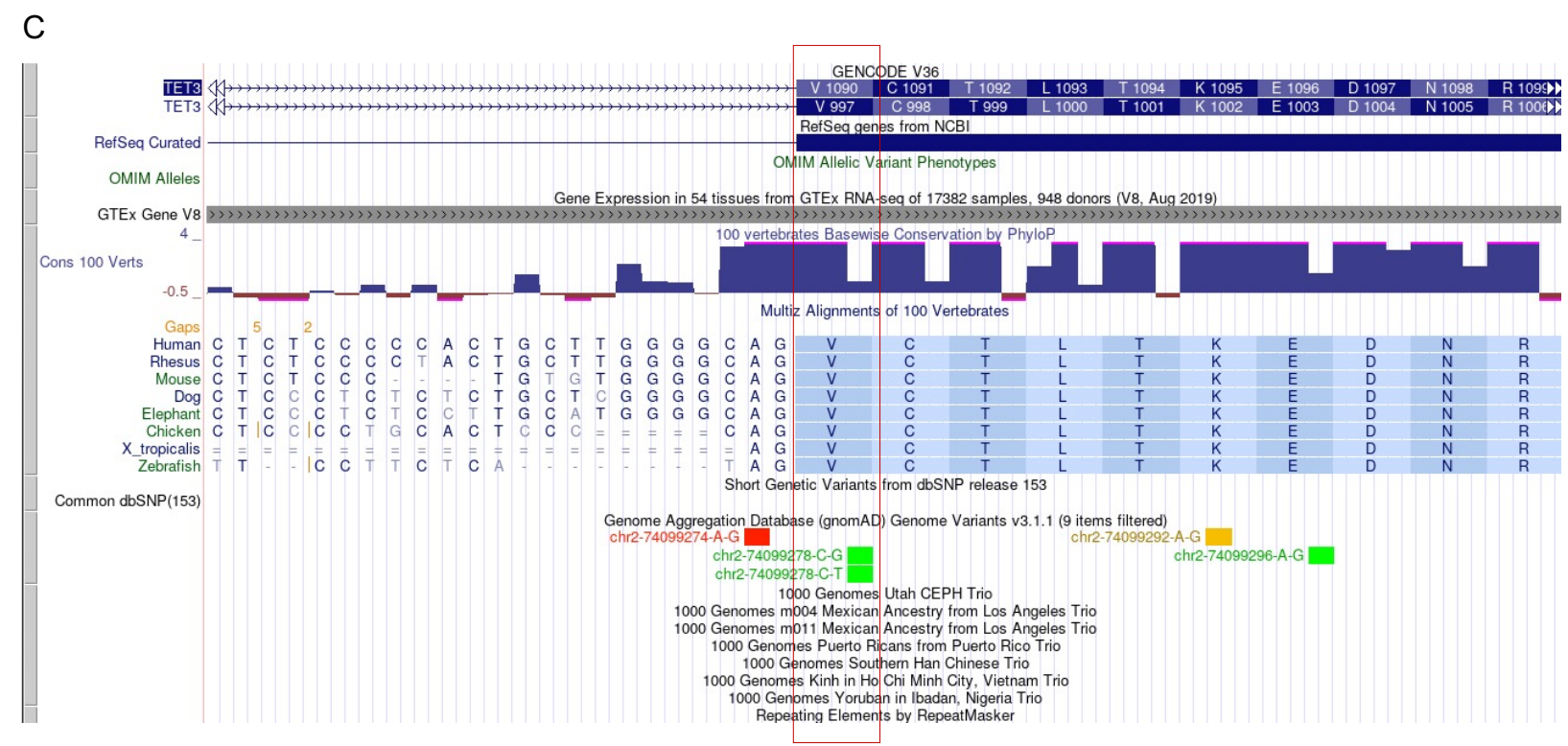

Supplementary Figure S15 cont'd: (C) Genomic variation analysis of TET3 V1090A (chr2:74,099,277 T>C) ANNOVAR (https://wannovar.wglab.org; Query: “2 7409927774099277 T C"). No SNPs were found in the region of interest (TET3 V1090A). 


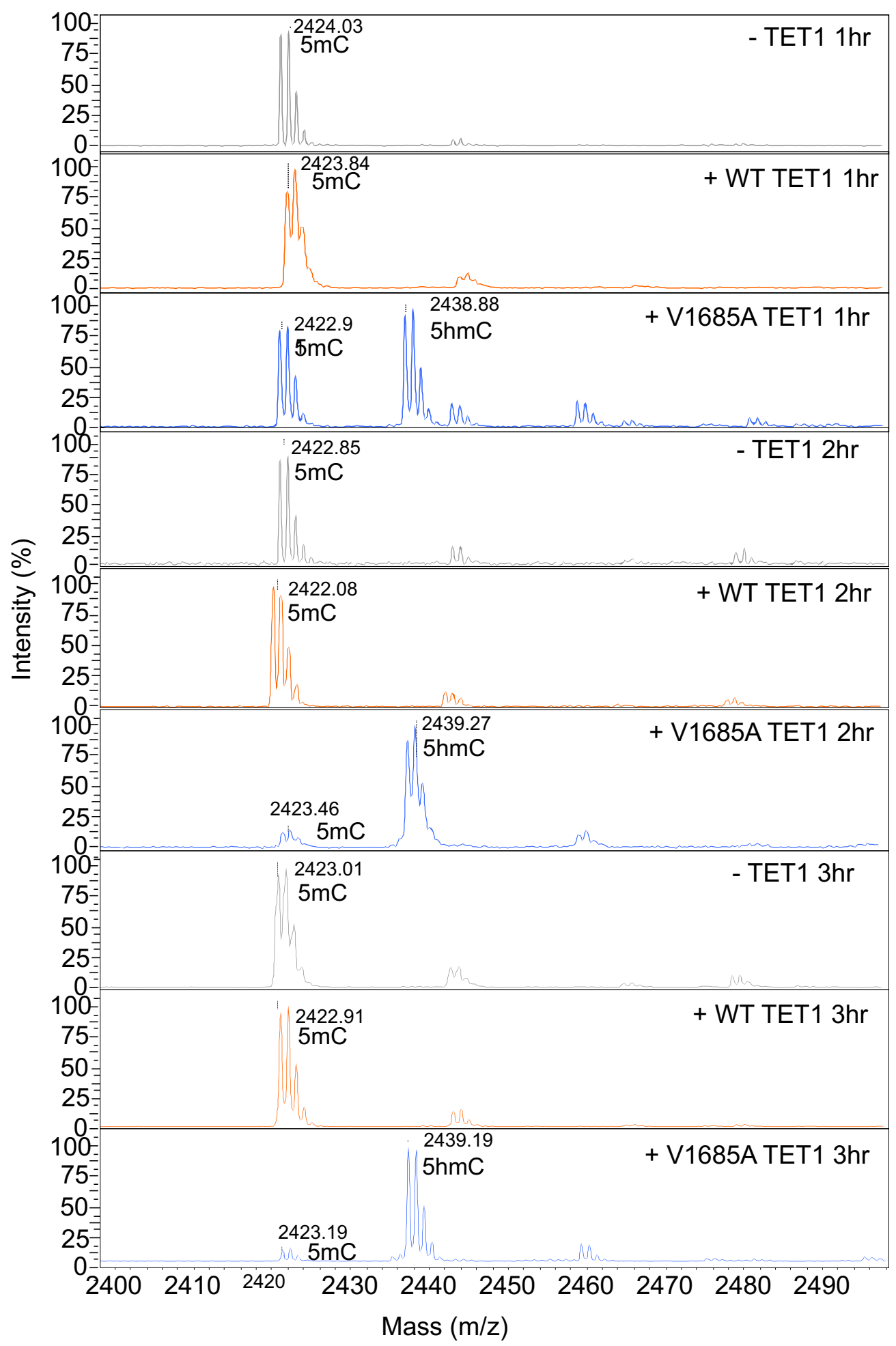

Supplementary Figure S16: MALDI-MS spectra showing activity of wild type TET1 and its V1685A mutant towards 5mC-containing 8-nt DNA substrate (CAC5mCGGTG) using cofactor 2KG. WT TET1 showed marginal (<3\%) activity on this particular substrate. 


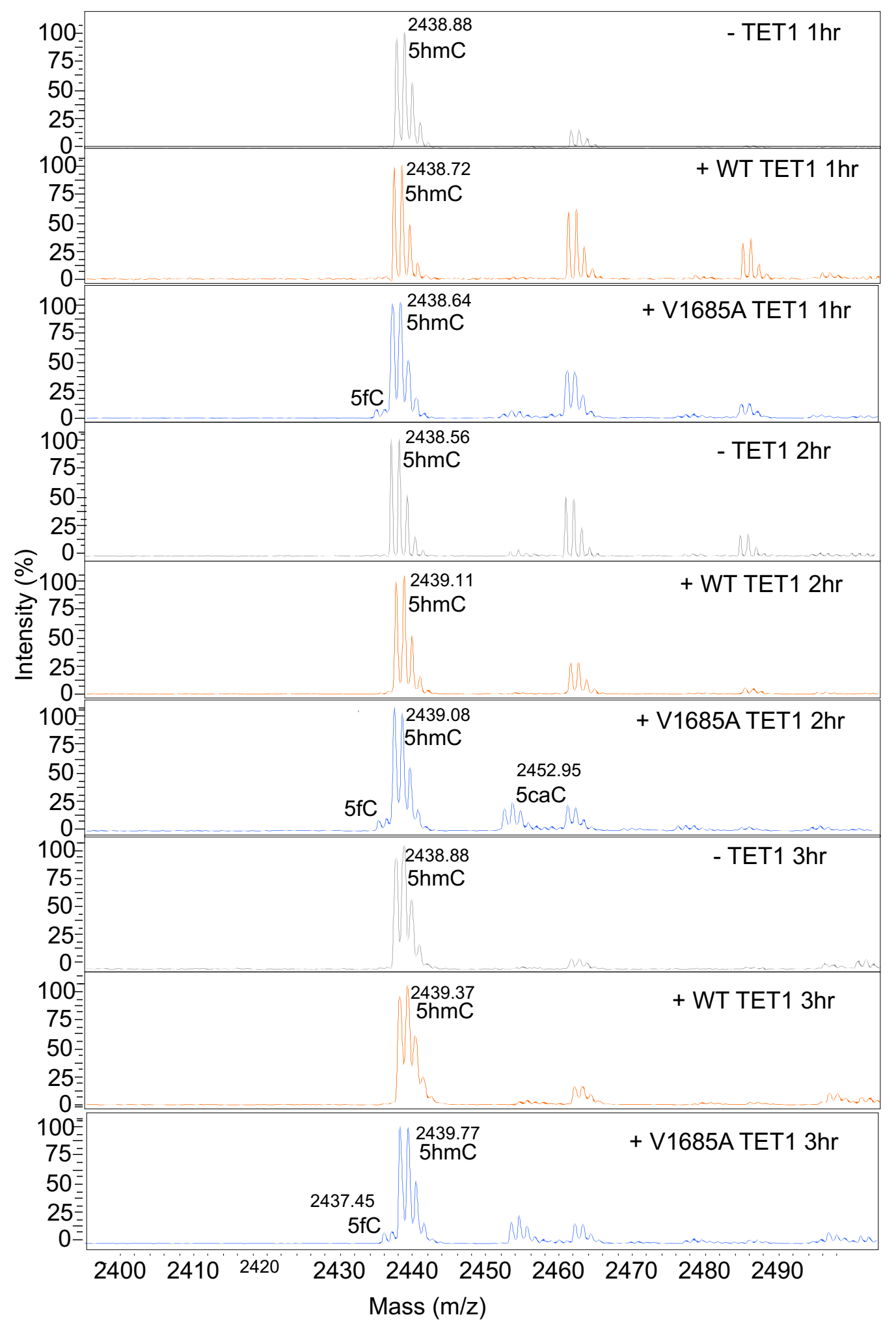

Supplementary Figure S17: MALDI-MS spectra showing activity of wild type TET1 and its V1685A mutant towards 5hmC-containing 8-nt DNA substrate (CAC5hmCGGTG) using cofactor $2 \mathrm{KG}$. WT TET1 showed marginal $(<3 \%)$ on this particular substrate. 


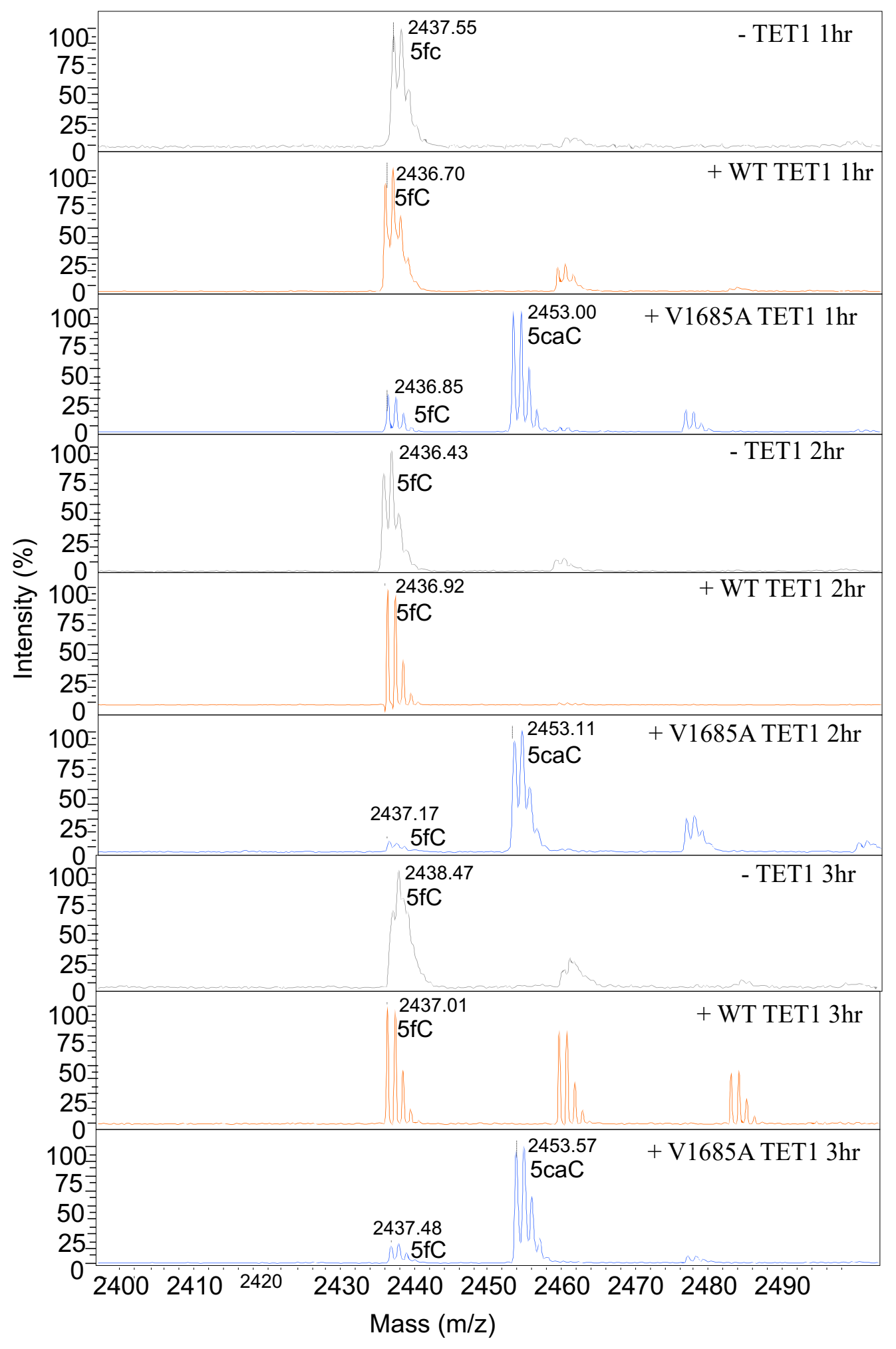

Supplementary Figure S18: MALDI-MS spectra showing activity of wild type TET1 and its V1685A mutant towards 5fC-containing 8-nt DNA substrate (CAC5fCGGTG) using cofactor 2KG. WT TET1 showed marginal activity $(<3 \%)$ on this particular substrate. 
(A1)

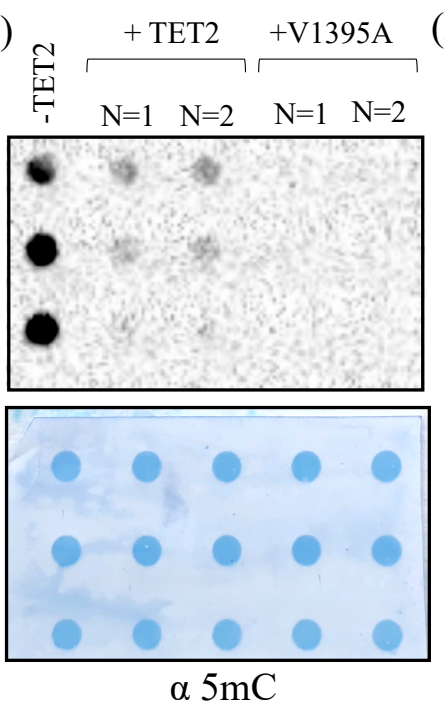

(A2)
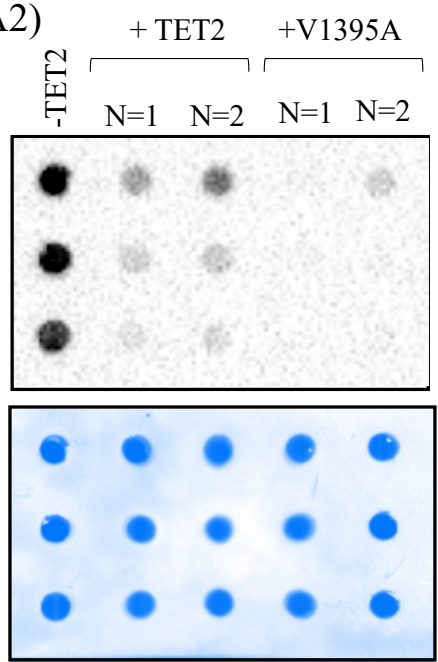

$\alpha 5 \mathrm{mC}$

(D)

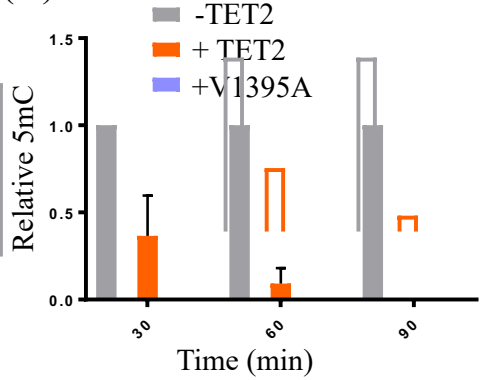

(B1)
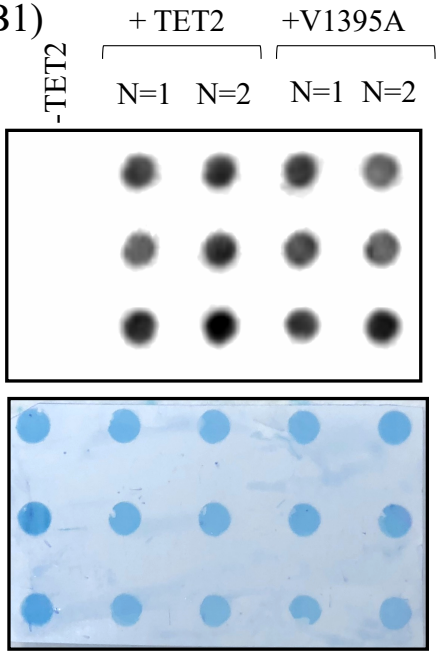

$\alpha 5 \mathrm{hmC}$

(B2)
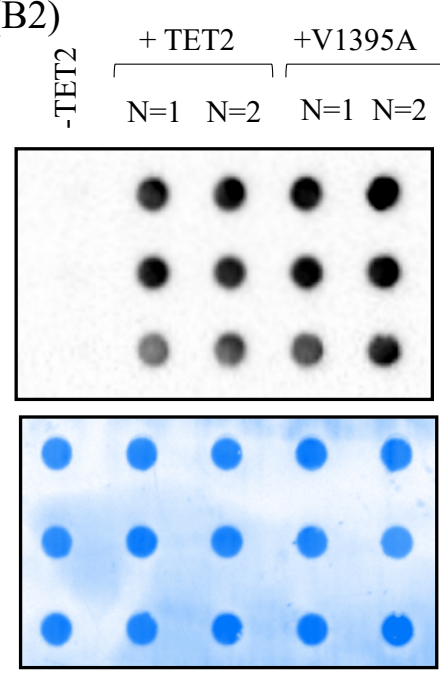

$\alpha 5 \mathrm{hmC}$

(E)

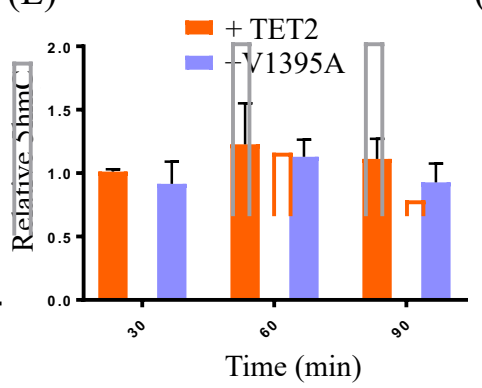

(C1)
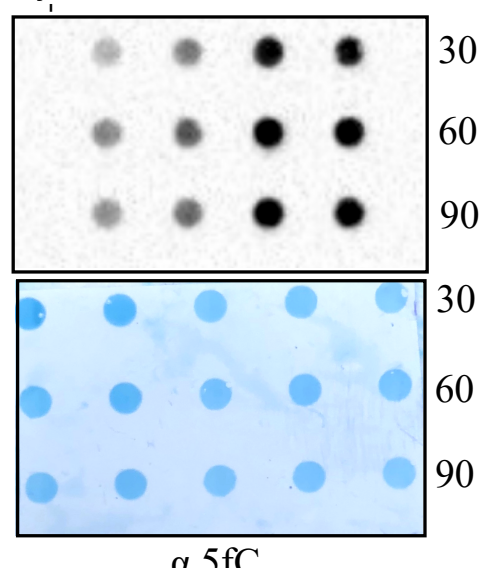

(C2)
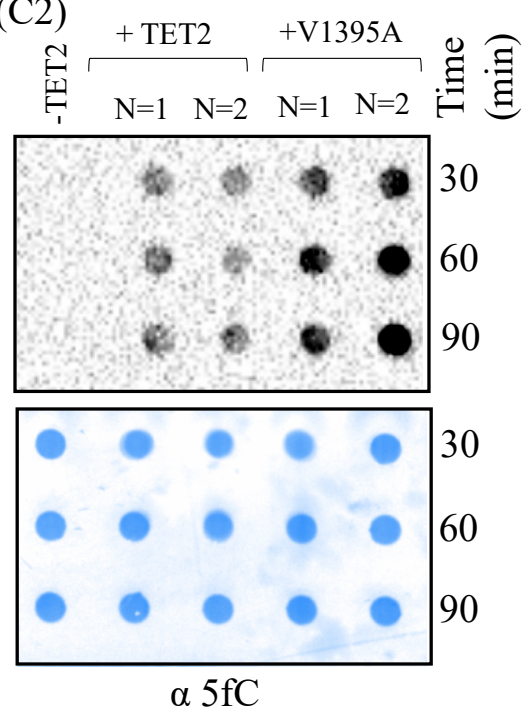

(F)

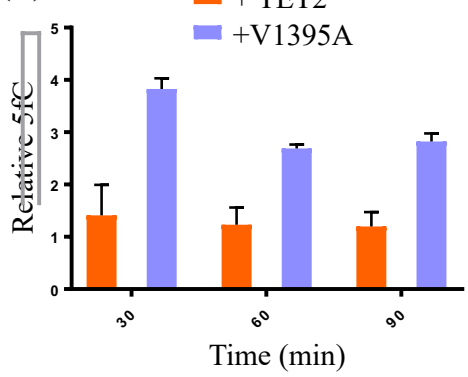

Supplementary Figure S19: Dot blot assay showing time-dependent, in-vitro activity of wild type TET2 and V1395A mutant on genomic DNA isolated from non-treated HEK293T cells. (A1 and A2) are two independent biological replicates showing changes in $5 \mathrm{mC}$ level using $5 \mathrm{mC}$ antibody. (B1 and B2) are two independent biological replicates showing changes in 5hmC level using 5hmC antibody. (C1 and C2) are two independent biological replicates showing changes in $5 \mathrm{fC}$ level 
using 5fC antibody. Methylene blue is used as loading control for the same amount of DNA used in each assay. Bar diagram provides relative fold change in $5 \mathrm{mC} \mathrm{(D),5hmC} \mathrm{(E)} \mathrm{and} 5 \mathrm{fC} \mathrm{(F)} \mathrm{level.}$ Quantification was performed using Image J software. The mutant showed higher activity on $5 \mathrm{mC}$ as revealed by complete consumption of $5 \mathrm{mC}$ within 30 minutes (D). Slightly lower amount of $5 \mathrm{hmC}$ for V1395A compared to wild type TET2 (E) is likely indicative of higher activity of the mutant on $5 \mathrm{hmC}$ on genomic DNA to generate more of $5 \mathrm{fC}(\mathbf{F})$ and $5 \mathrm{caC}$ (Figure $4 \mathrm{~A}$ in the manuscript).

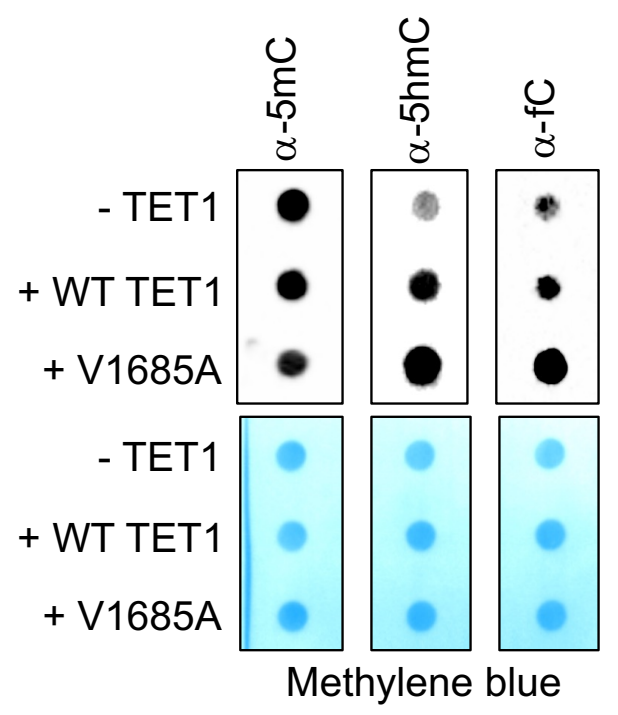

Supplementary Figure S20: Dot blot assay showing higher enzymatic activity (performed invitro) of TET1-V1685A mutant compared to wild type TET1 on genomic DNA isolated from HEK293T cells. Methylene Blue as loading control to demonstrate that equal amount of DNA was used in each assay. The mutant oxidized $5 \mathrm{mC}$ present in the genomic DNA to a significant degree with concomitant increase in $5 \mathrm{hmC}$ and $5 \mathrm{fC}$ level. 


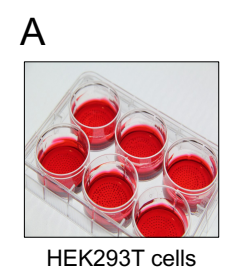

HEK293T cells

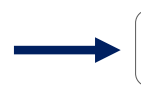

Cells were washed (3xPBS) and collected

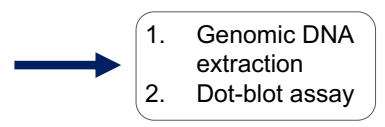

B
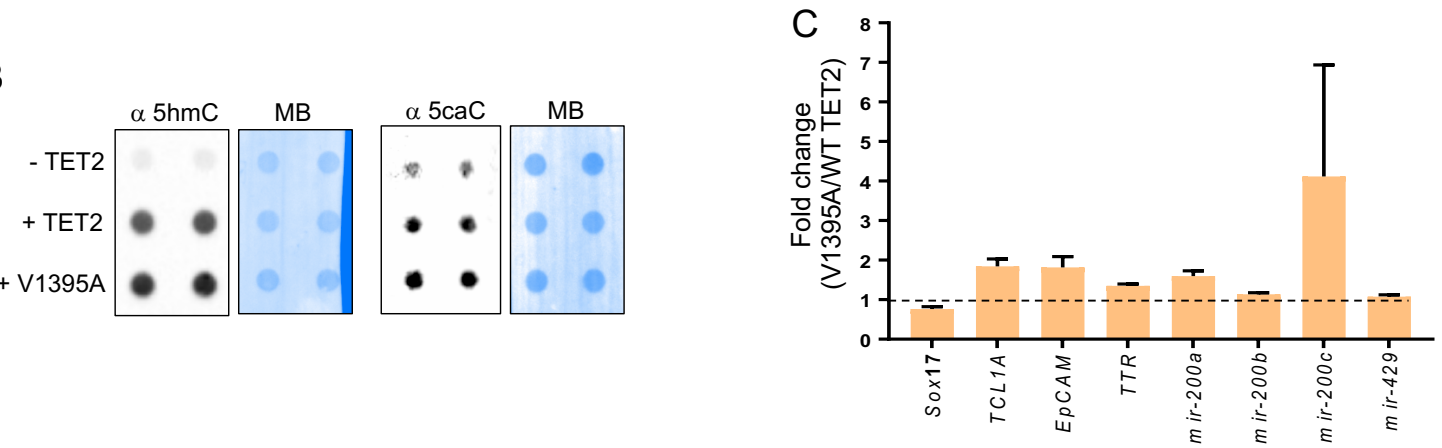

Supplementary Figure S21: (A) Schematic showing steps to examine in-cellulo activity of wild type TET2 and V1395A mutant. (B) Dot-blots confirming higher level of 5hmC and 5caC generated by mutant over wild type. These are biological replicates of the data provided in Figure 5B in the manuscript. (C) Fold change (mutant/wild-type) in enrichment of the selected genes using $5 \mathrm{hmC}$ antibody as revealed by DIP-qPCR. PCR measurements were performed in duplicate. The average cycle thresholds $\left(\mathrm{C}_{\mathrm{t}}\right)$ for the replicates were calculated to yield one value per primer set for each biological replicate and normalized to input using the formula:

$2 \mathrm{C}_{\mathrm{t} \text { input }}-\mathrm{C}_{\mathrm{t}}$ immunoprecipitation $)$. The Input \% value for each sample is then calculated using $100 * 2 \Delta \mathrm{Ct}$ [normalized DIP]. Averages and standard deviations of the normalized biological replicate values were plotted in the figures. 

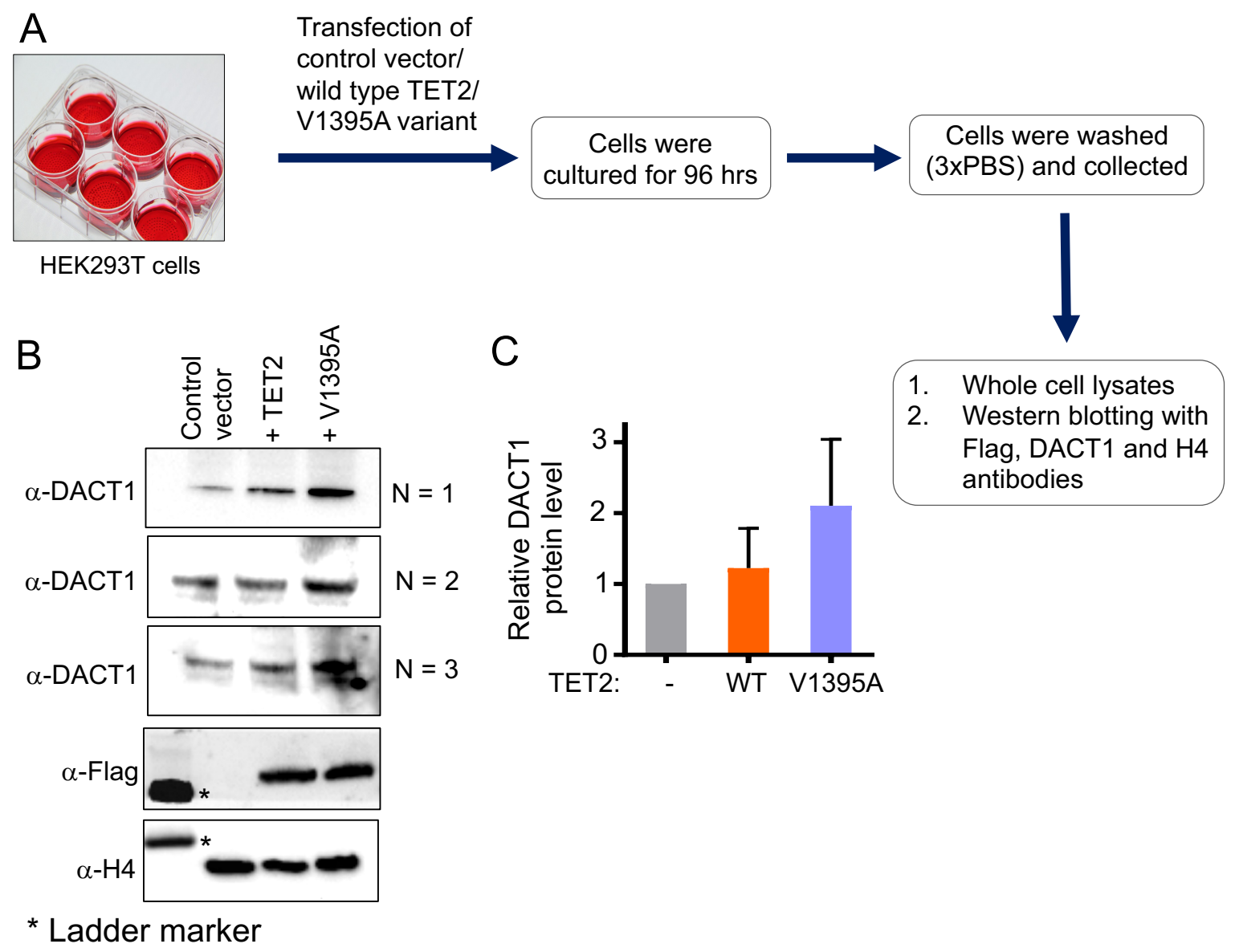

Supplementary Figure S22: (A) Schematic showing steps to examine in-cellulo activity of wild type TET2 and V1395A mutant. (B) Western blot analysis of expression of DACT1 as a function of TET2 and V1395A using anti-DACT1 antibody. Flag antibody is to demonstrate the similar expression level of wild type TET2 and the mutant. Histone H4 as loading control. (C) Quantitative representation of changes in DACT1 protein level based on western blots in $\mathbf{B}$. 


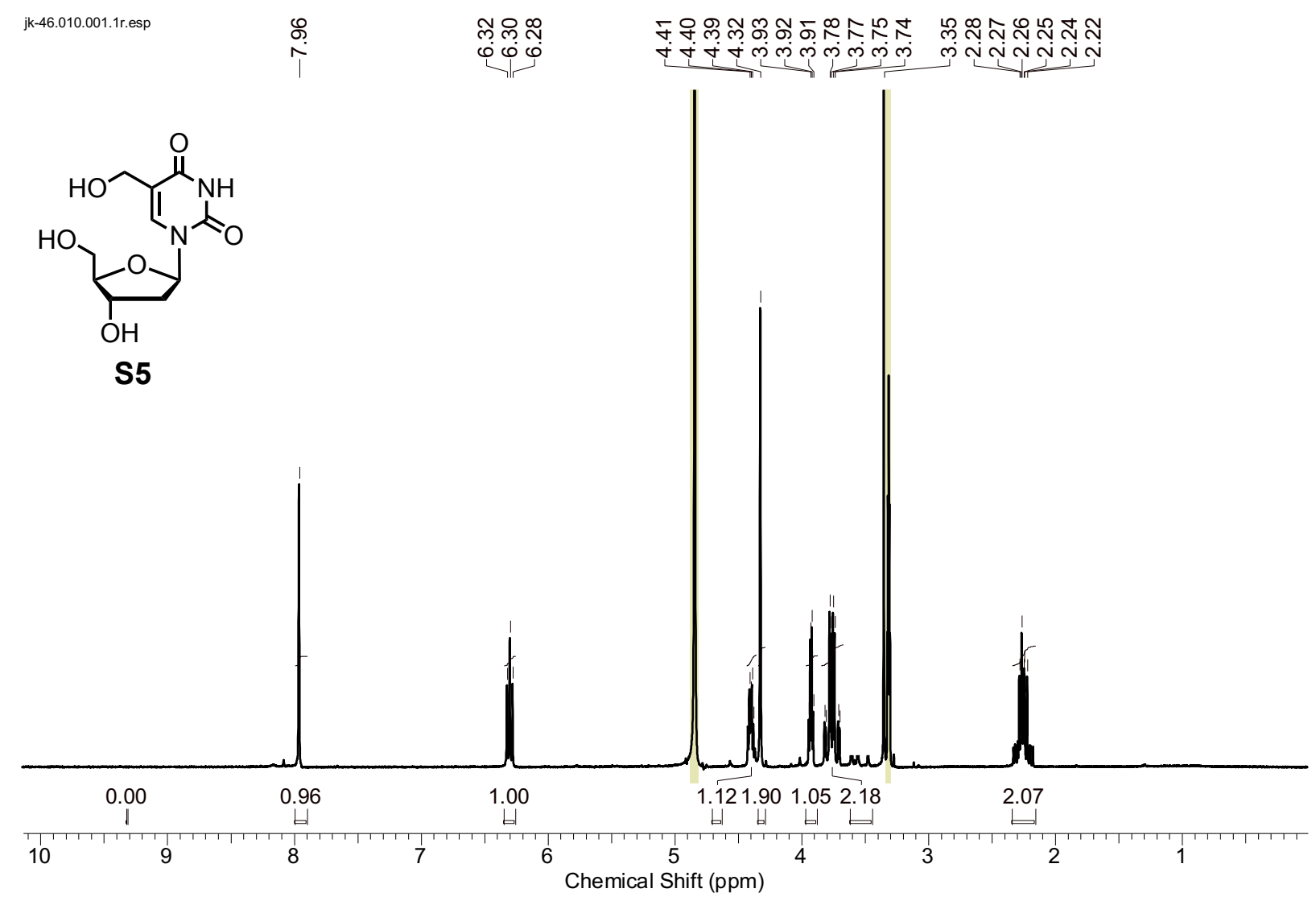

Supplementary Figure S23: ${ }^{1} \mathrm{H}$ NMR spectrum of S5 in $\mathrm{CD}_{3} \mathrm{OD}$. 


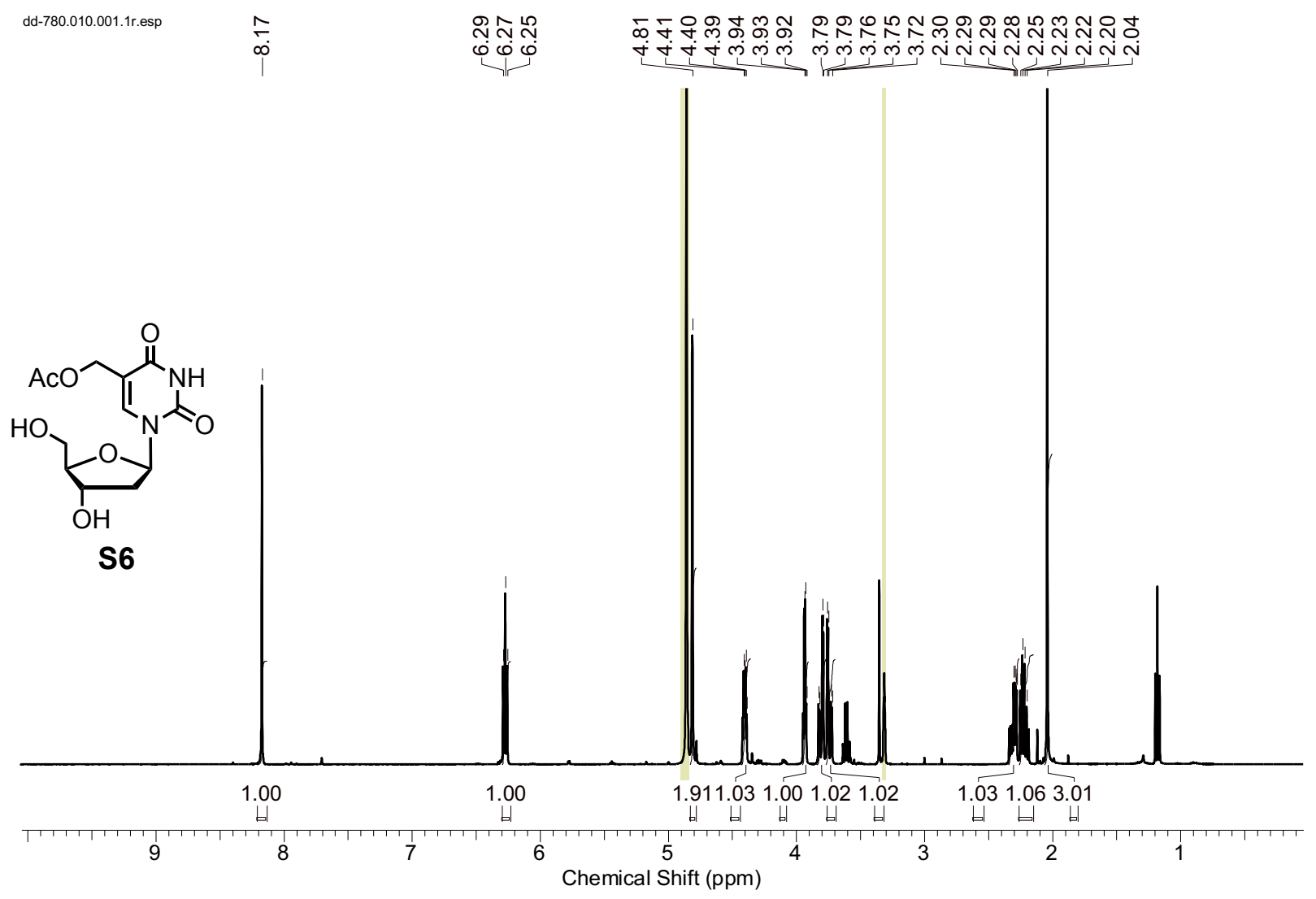

Supplementary Figure S24: ${ }^{1} \mathrm{H}$ NMR spectrum of S6 in $\mathrm{CD}_{3} \mathrm{OD}$. 


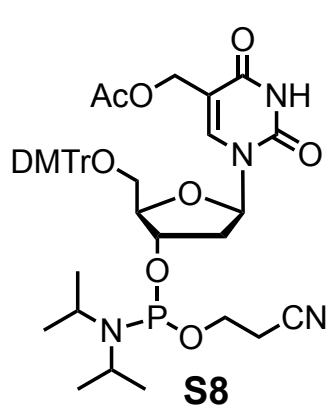

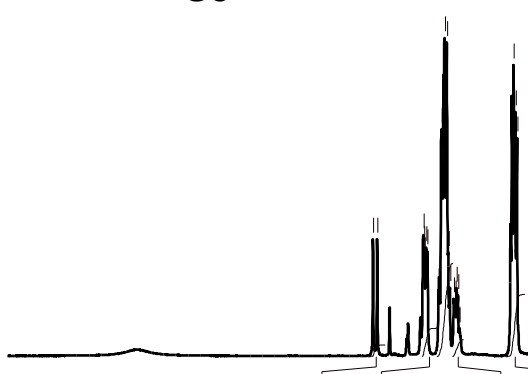

0.771 .896 .171 .134 .131 .00

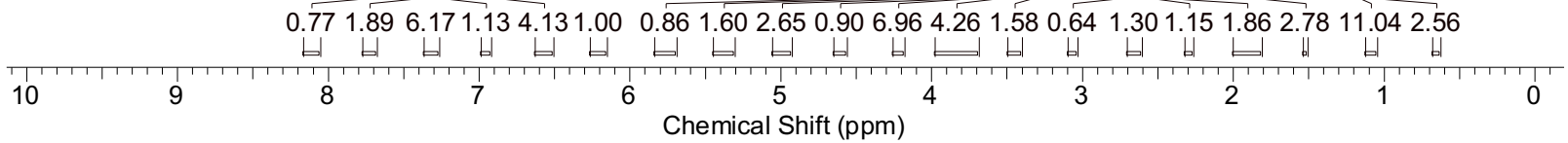

Supplementary Figure S25: ${ }^{1} \mathrm{H}$ NMR spectrum of $\mathbf{S 8}$ in $\mathrm{CD}_{3} \mathrm{CN}$. 


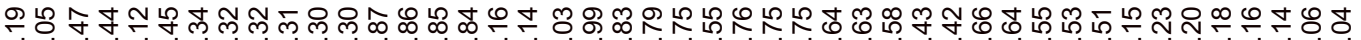

の̆́
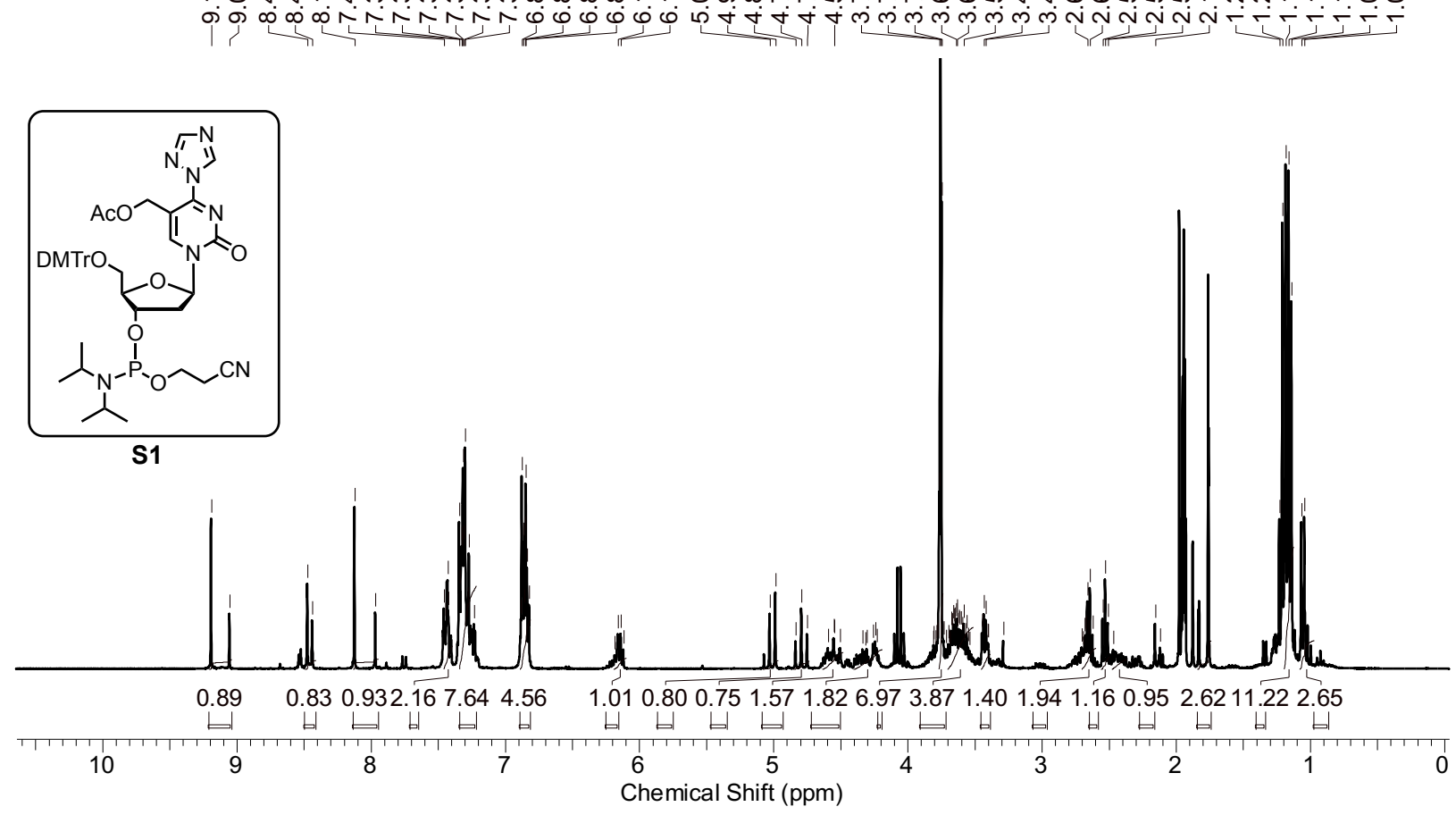

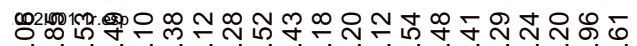
रंष

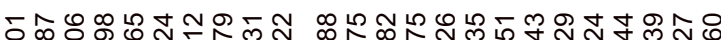

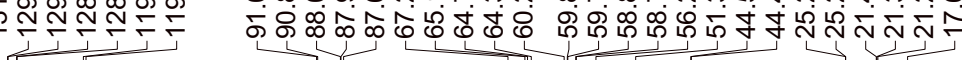

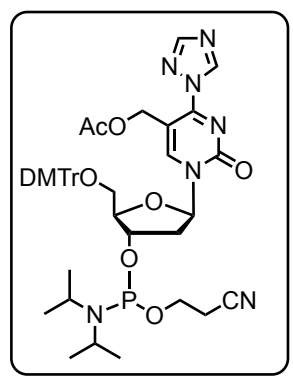

S1
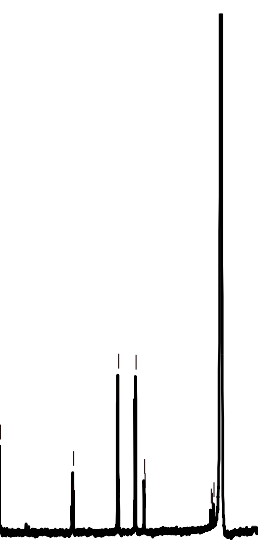

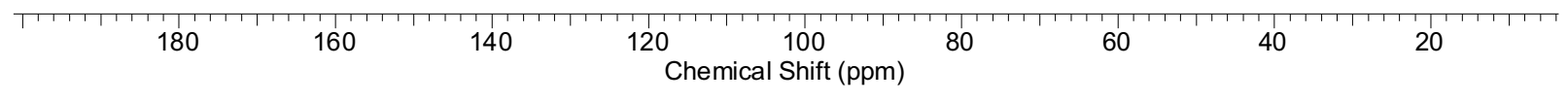

Supplementary Figure S26: ${ }^{1} \mathrm{H}$ and ${ }^{13} \mathrm{C}$ NMR spectra of $\mathbf{S 1}$ in $\mathrm{CD}_{3} \mathrm{CN}$. 


\begin{tabular}{|c|c|c|c|c|c|}
\hline \multicolumn{3}{|c|}{$\begin{array}{l}\text { C: XcaliburidatallslamI73566ESIP } \\
\text { no acid }\end{array}$} & \multicolumn{2}{|c|}{ 4/23/2015 4:26:43 PM } & DD-799 \\
\hline \multirow{2}{*}{\multicolumn{6}{|c|}{$\begin{array}{l}73566 \text { ESIP\#28-80 RT: } 0.20-0.47 \mathrm{AV}: 53 \\
\mathrm{~T}: \text { FTMS }+ \text { p ESI Full ms }[100.00-1500.00] \\
\mathrm{m} / \mathrm{z}=854.00000-855.00000\end{array}$}} \\
\hline & & & & & \\
\hline $\mathrm{m} / \mathrm{z}$ & Intensity & Relative & Theo. Mass & $\begin{array}{l}\text { Delta } \\
(\mathrm{ppm})\end{array}$ & Composition \\
\hline 854.36737 & 17506066.0 & 100.00 & 854.36369 & 4.31 & $\mathrm{C}_{44} \mathrm{H}_{53} \mathrm{O}_{9} \mathrm{~N}_{7} \mathrm{P}$ \\
\hline
\end{tabular}

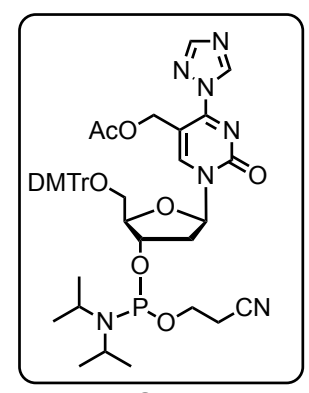

S1

73566ESIP \#29-79 RT: 0.20-0.47 AV: $51 \quad$ NL: $1.75 E 7$

T: FTMS + p ESI Full ms [100.00-1500.00]

854.36738

$z=1$

$\mathrm{C}_{44} \mathrm{H}_{53} \mathrm{O}_{9} \mathrm{~N}_{7} \mathrm{P}$

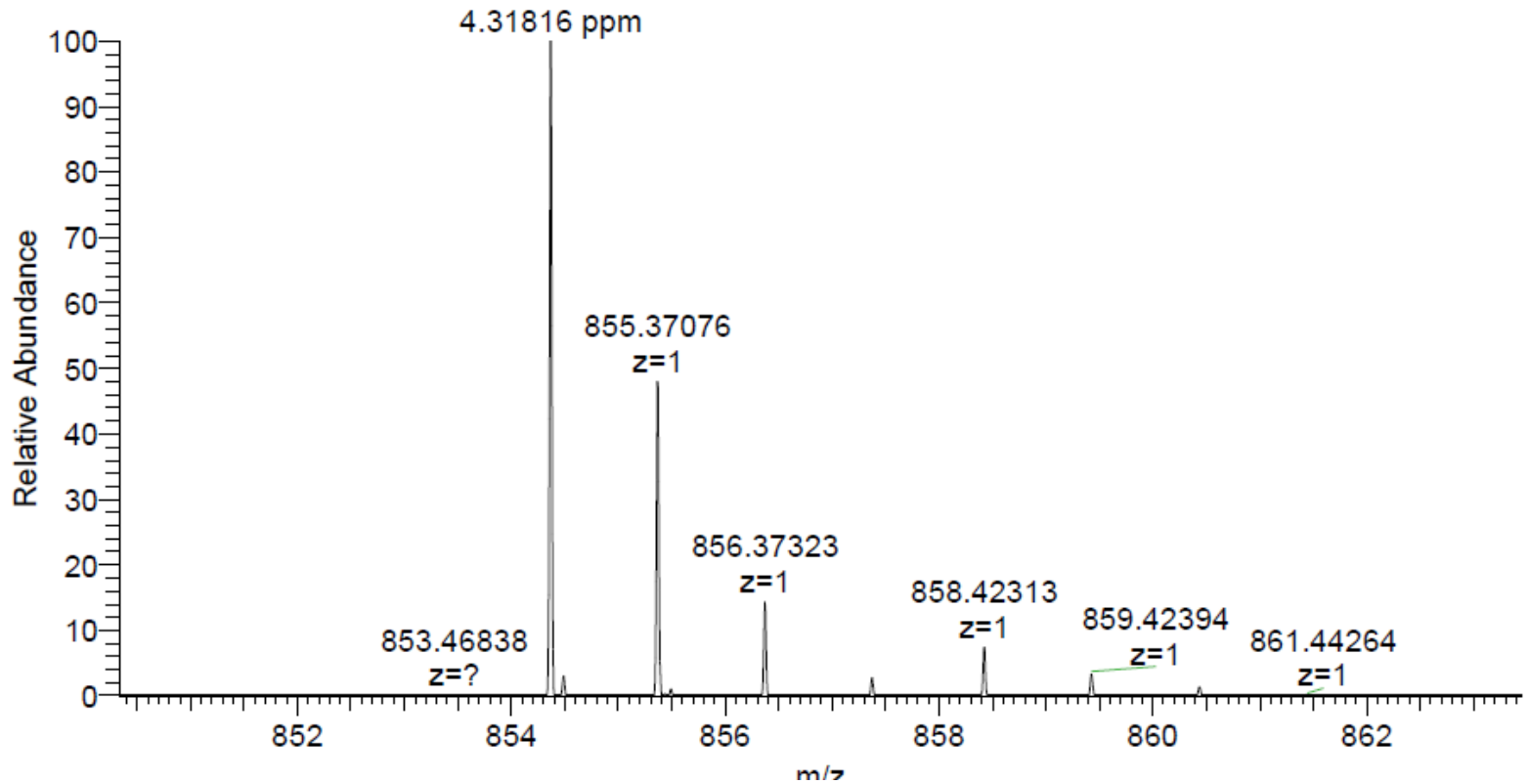

Supplementary Figure S27: HRMS spectrum of S1. 


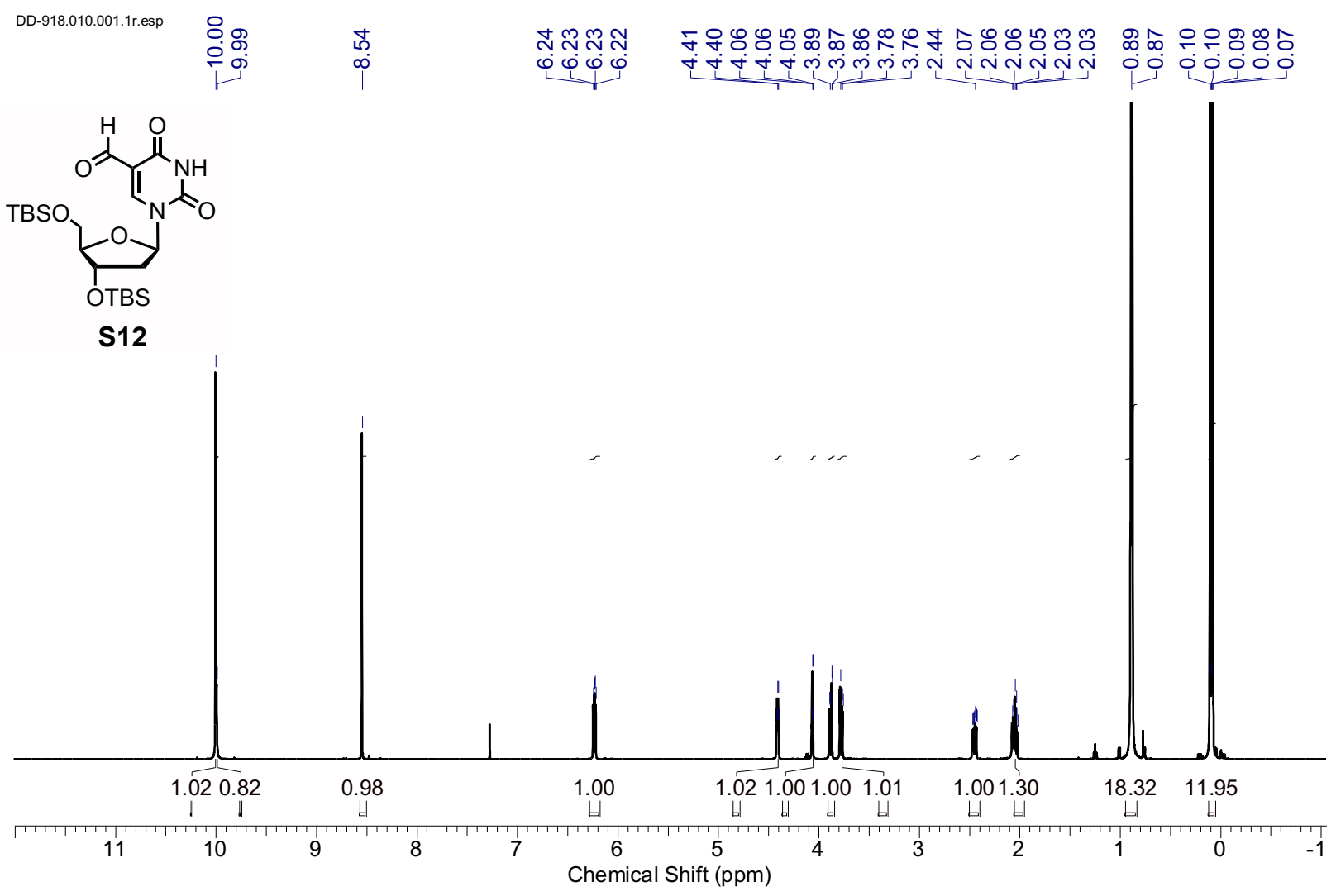

Supplementary Figure S28: ${ }^{1} \mathrm{H}$ NMR spectrum of $\mathbf{S 1 2}$ in $\mathrm{CDCl}_{3}$. 


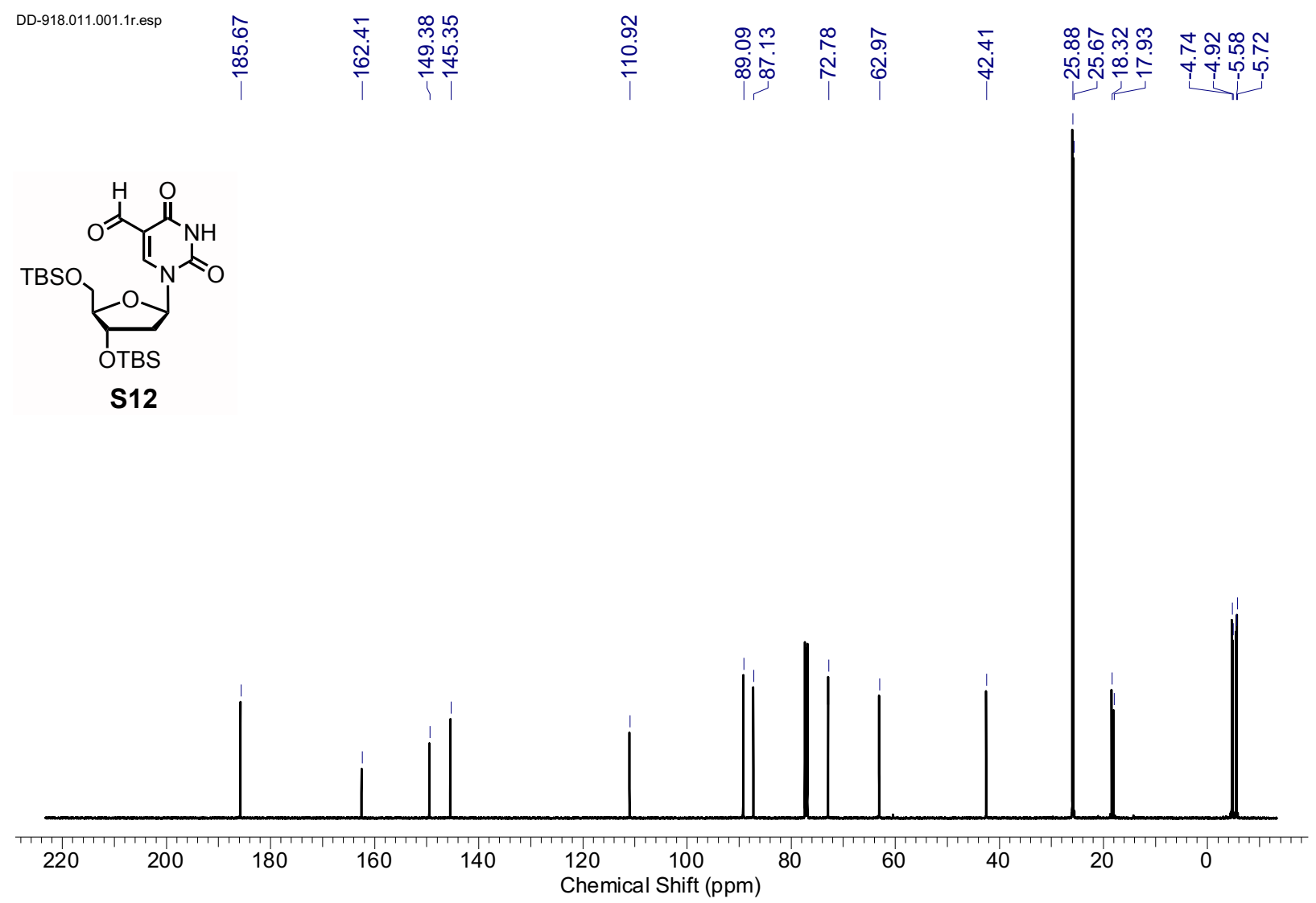

Supplementary Figure S29: ${ }^{13} \mathrm{C}$ NMR spectrum of $\mathbf{S 1 2}$ in $\mathrm{CDCl}_{3}$. 


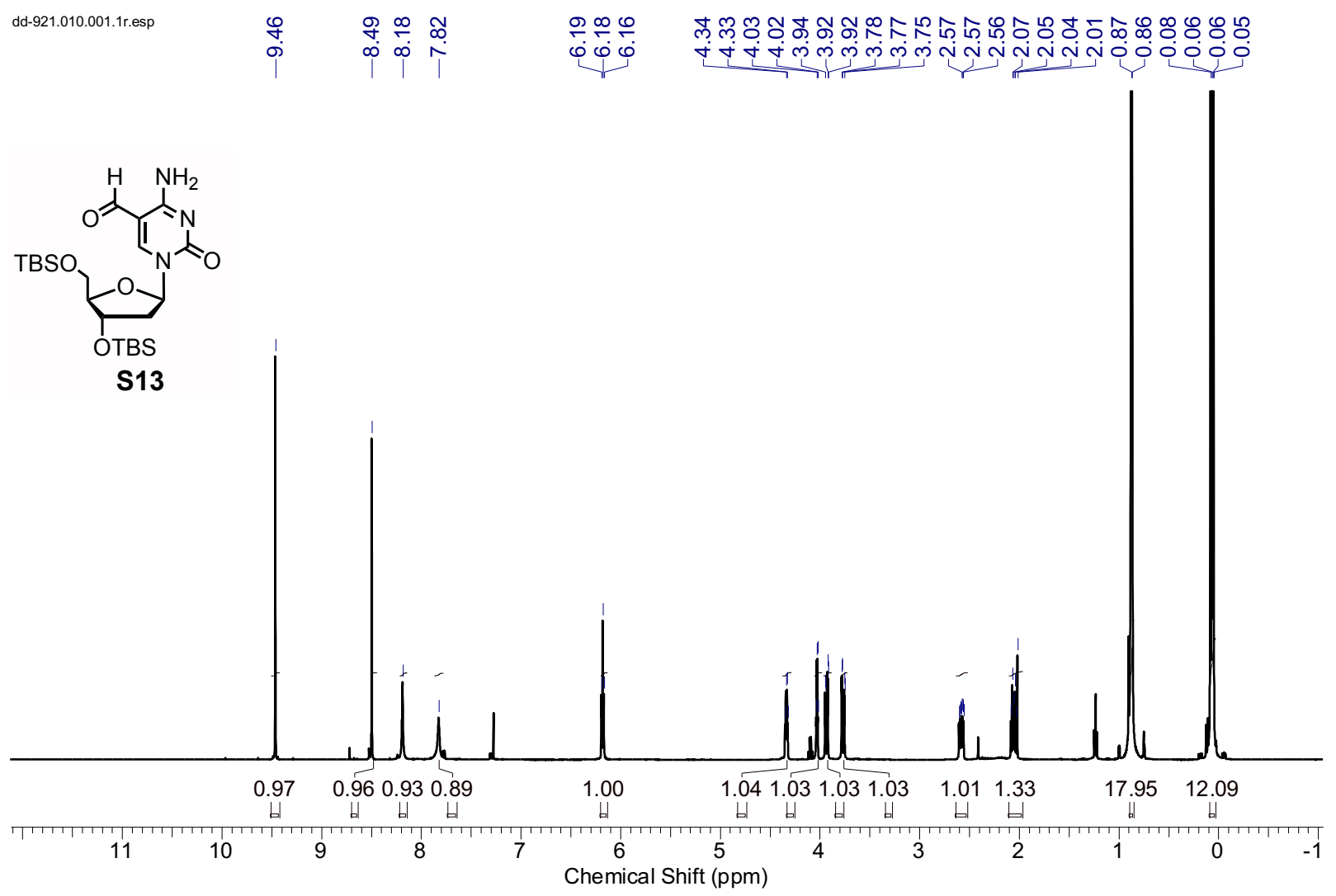

Supplementary Figure S30: ${ }^{1} \mathrm{H}$ NMR spectrum of $\mathbf{S 1 3}$ in $\mathrm{CDCl}_{3}$. 


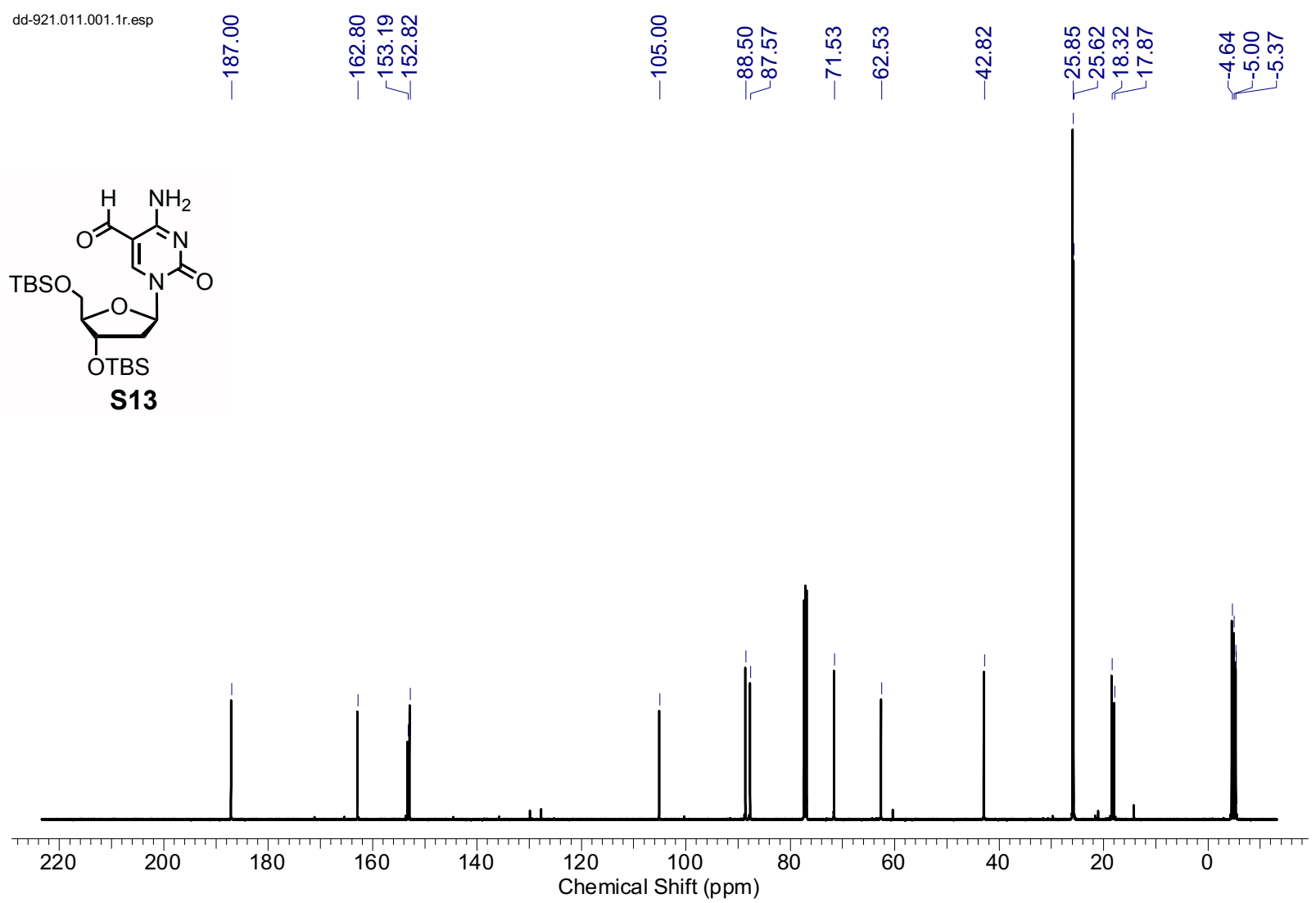

Supplementary Figure S31: ${ }^{13} \mathrm{C}$ NMR spectrum of $\mathbf{S 1 3}$ in $\mathrm{CDCl}_{3}$. 


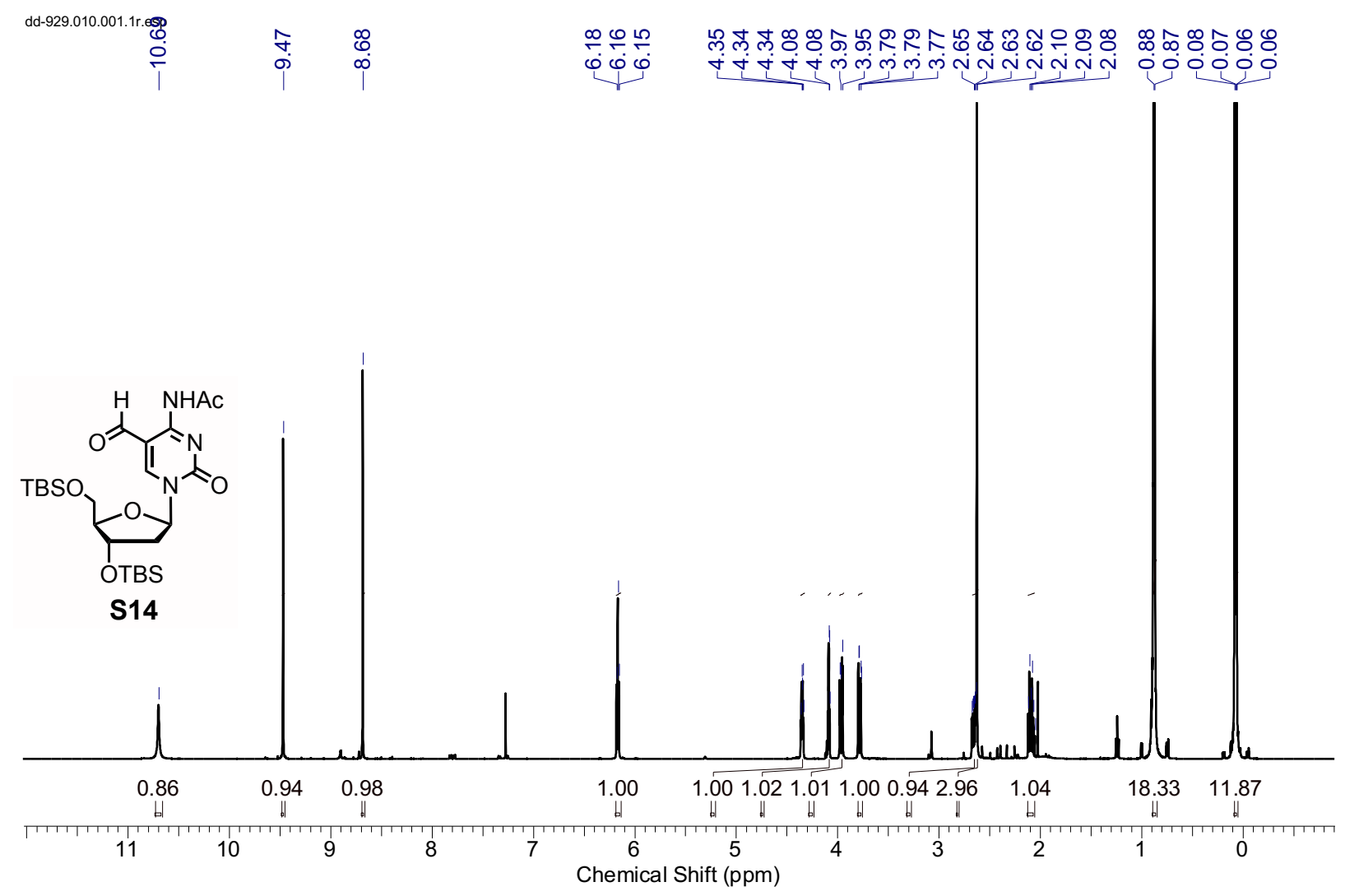

Supplementary Figure S32: ${ }^{1} \mathrm{H}$ NMR spectrum of $\mathbf{S 1 4}$ in $\mathrm{CDCl}_{3}$. 


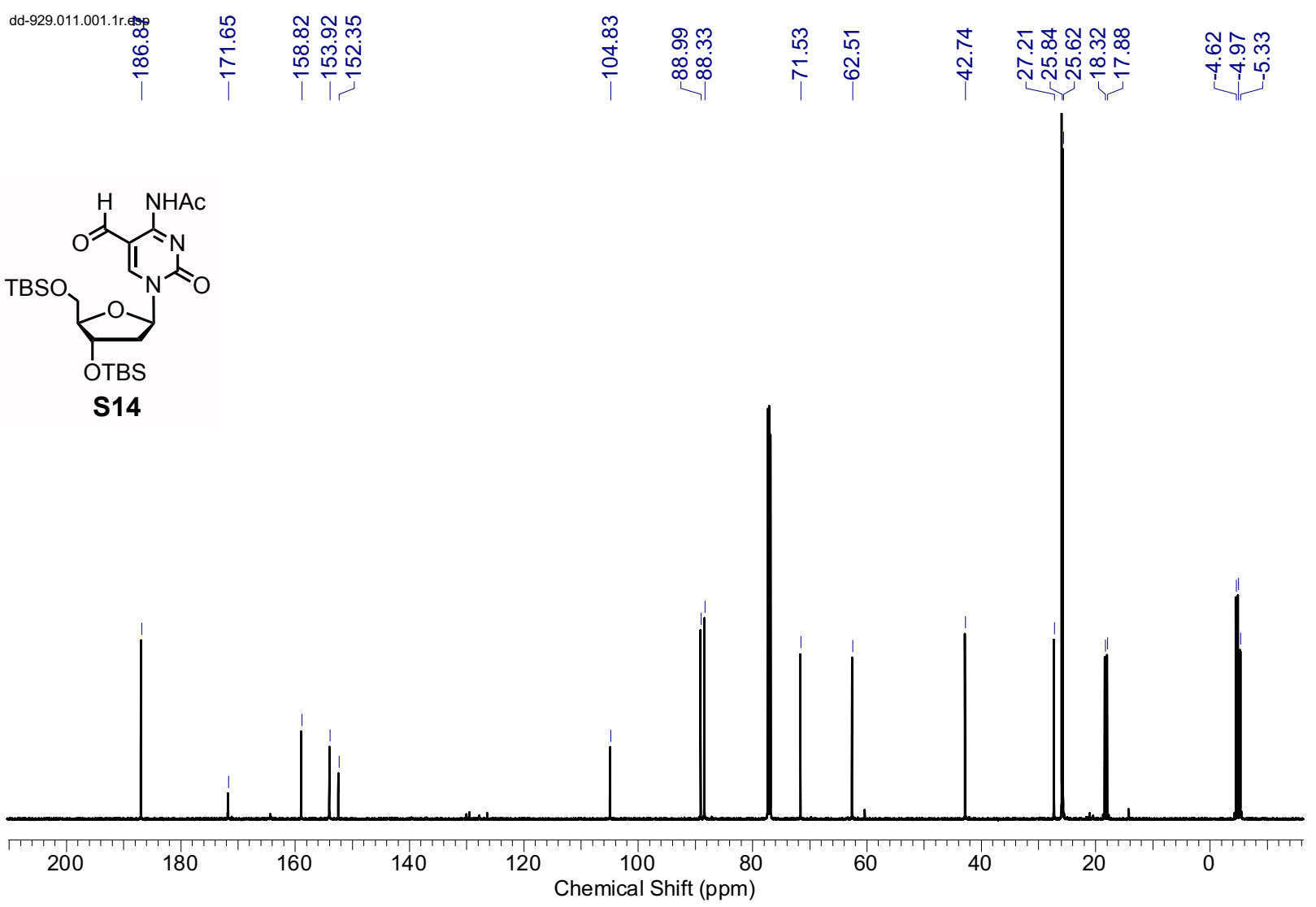

Supplementary Figure S33: ${ }^{13} \mathrm{C}$ NMR spectrum of $\mathbf{S 1 4}$ in $\mathrm{CDCl}_{3}$. 


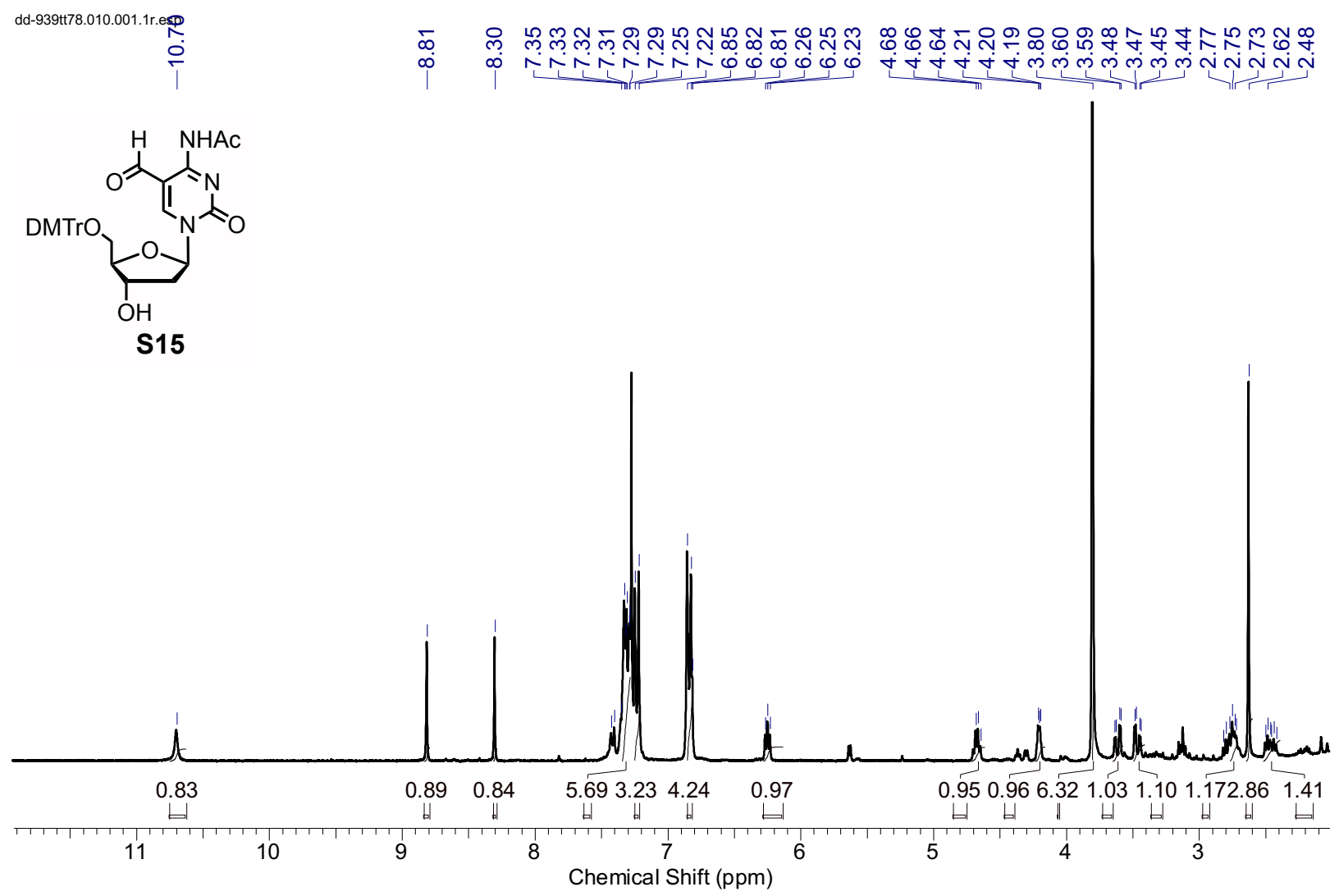

Supplementary Figure S34: ${ }^{1} \mathrm{H}$ NMR spectrum of $\mathbf{S 1 5}$ in $\mathrm{CDCl}_{3}$. 

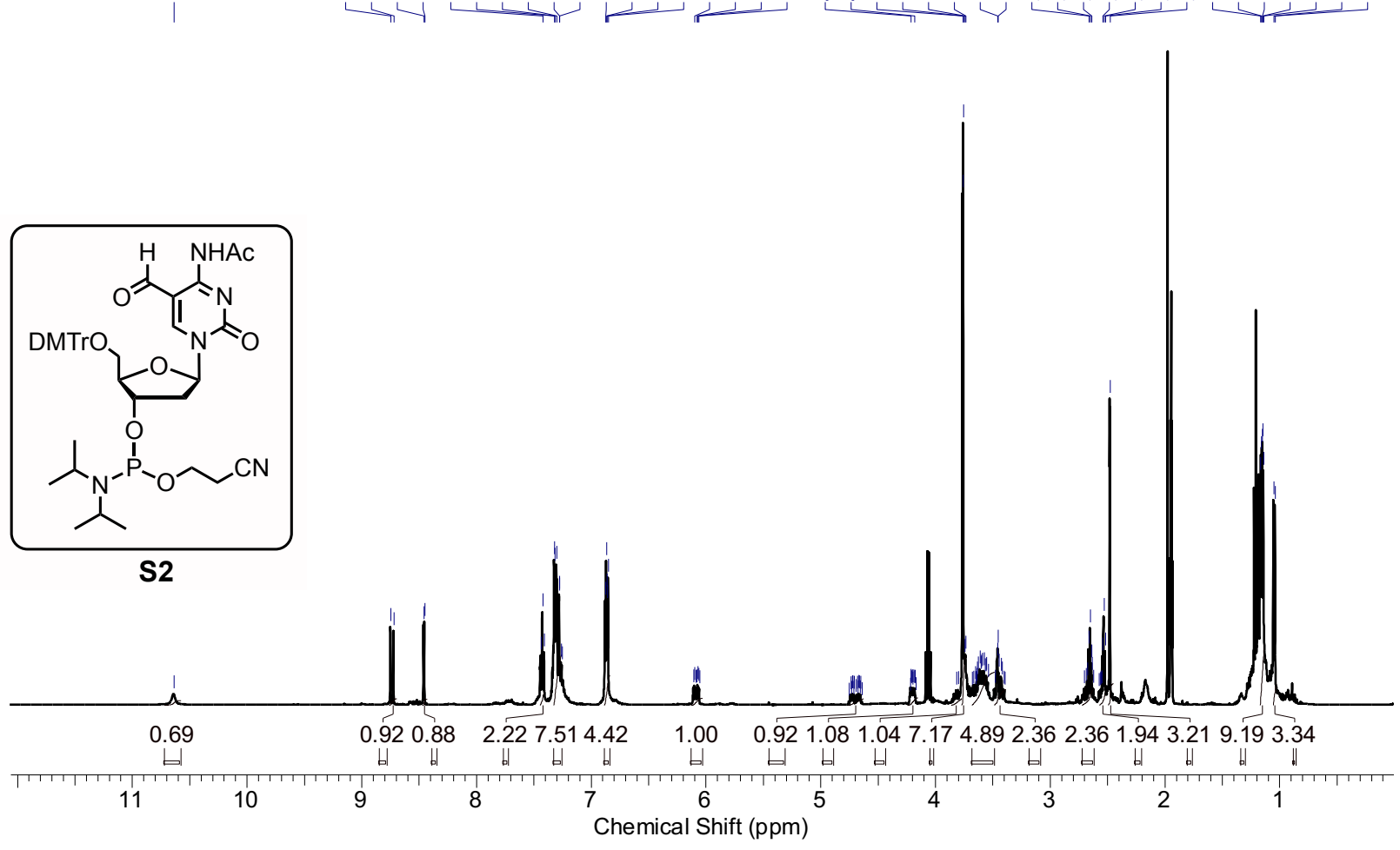

Supplementary Figure S35: ${ }^{1} \mathrm{H}$ NMR spectrum of S2 in $\mathrm{CD}_{3} \mathrm{CN}$. 

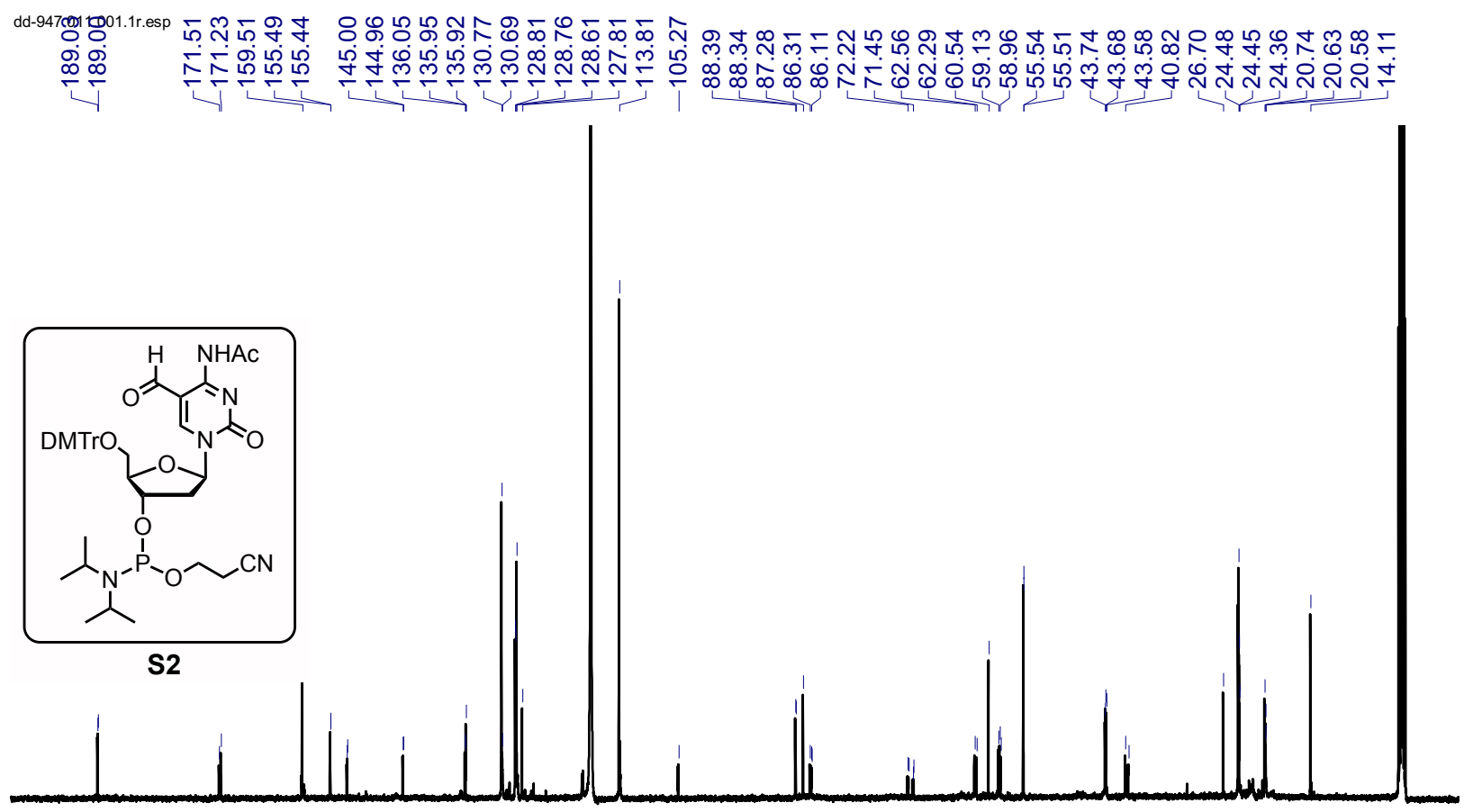

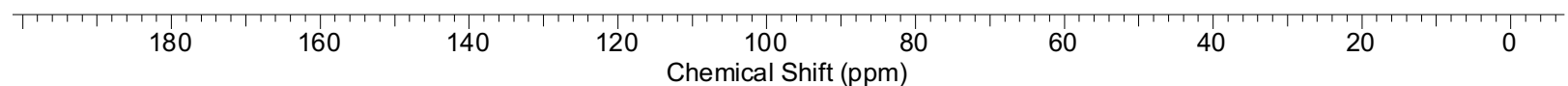

Supplementary Figure S36: ${ }^{13} \mathrm{C}$ NMR spectrum of $\mathbf{S 2}$ in $\mathrm{CD}_{3} \mathrm{CN}$. 


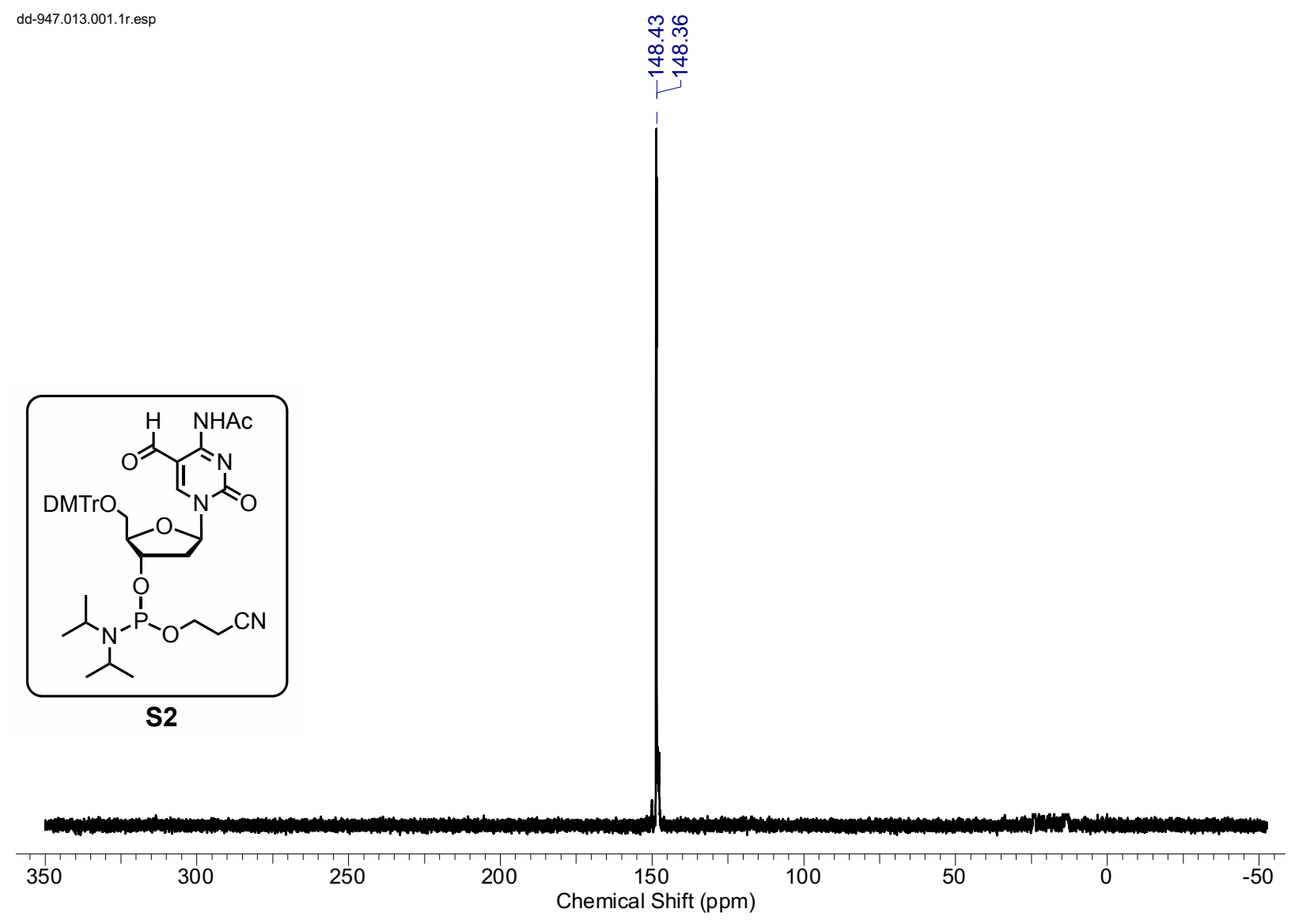

Supplementary Figure S37: ${ }^{31} \mathrm{P}$ NMR spectrum of $\mathbf{S 2}$ in $\mathrm{CD}_{3} \mathrm{CN}$. 


\begin{tabular}{|c|c|c|c|c|c|}
\hline \multicolumn{3}{|c|}{ C:Xcaliburidatallslaml74120ESIPN } & \multicolumn{2}{|l|}{ 07/31/15 15:26:46 } & DD-947 \\
\hline \multicolumn{6}{|c|}{$\begin{array}{l}74120 \text { ESIPN\#23-41 RT: } 0.22-0.40 \text { AV: } 10 \\
\text { T: FTMS + p ESI Ful1 ms [100.00-1500.00] } \\
\mathrm{m} / \mathrm{z}=800.00000-801.00000\end{array}$} \\
\hline $\mathrm{m} / \mathrm{z}$ & Intensity & Relative & Theo. Mass & $\begin{array}{l}\text { Delta } \\
\text { (ppm) }\end{array}$ & Composition \\
\hline 800.33981 & 456671520.0 & 100.00 & 800.34189 & -2.59 & $\mathrm{C}_{42} \mathrm{H}_{51} \mathrm{O}_{9} \mathrm{~N}_{5} \mathrm{P}$ \\
\hline
\end{tabular}

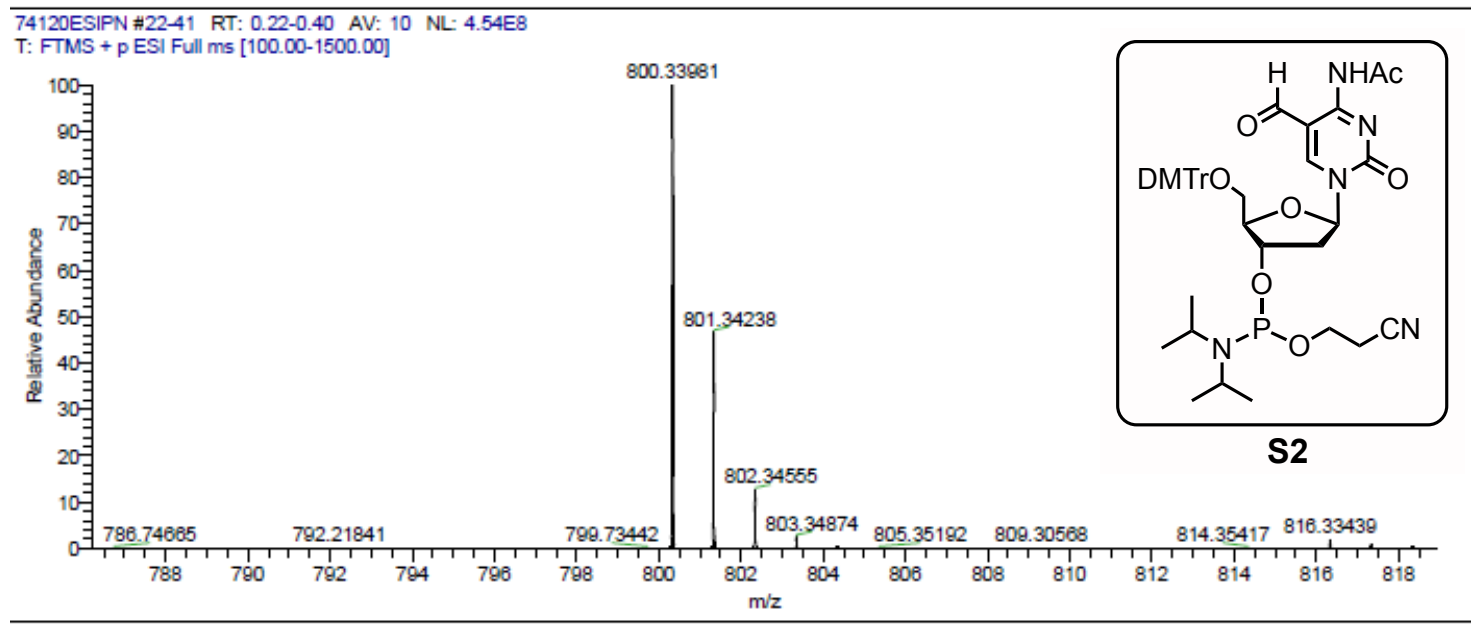

$74120 E S I P N=22-41$ RT: $0.22-0.40$ AV: 10 NL: $4.54 E 8$ T: FTMS + p ESI Full ms [100.00-1500.00]

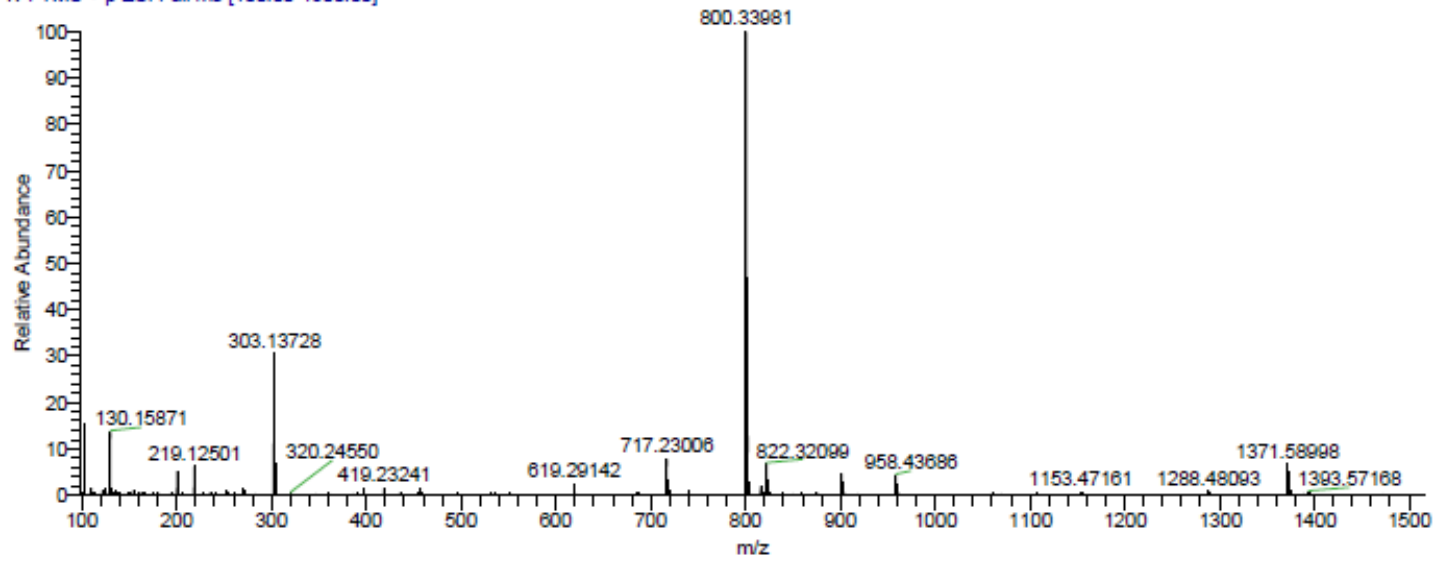

Supplementary Figure S38: HRMS spectrum of S2. 


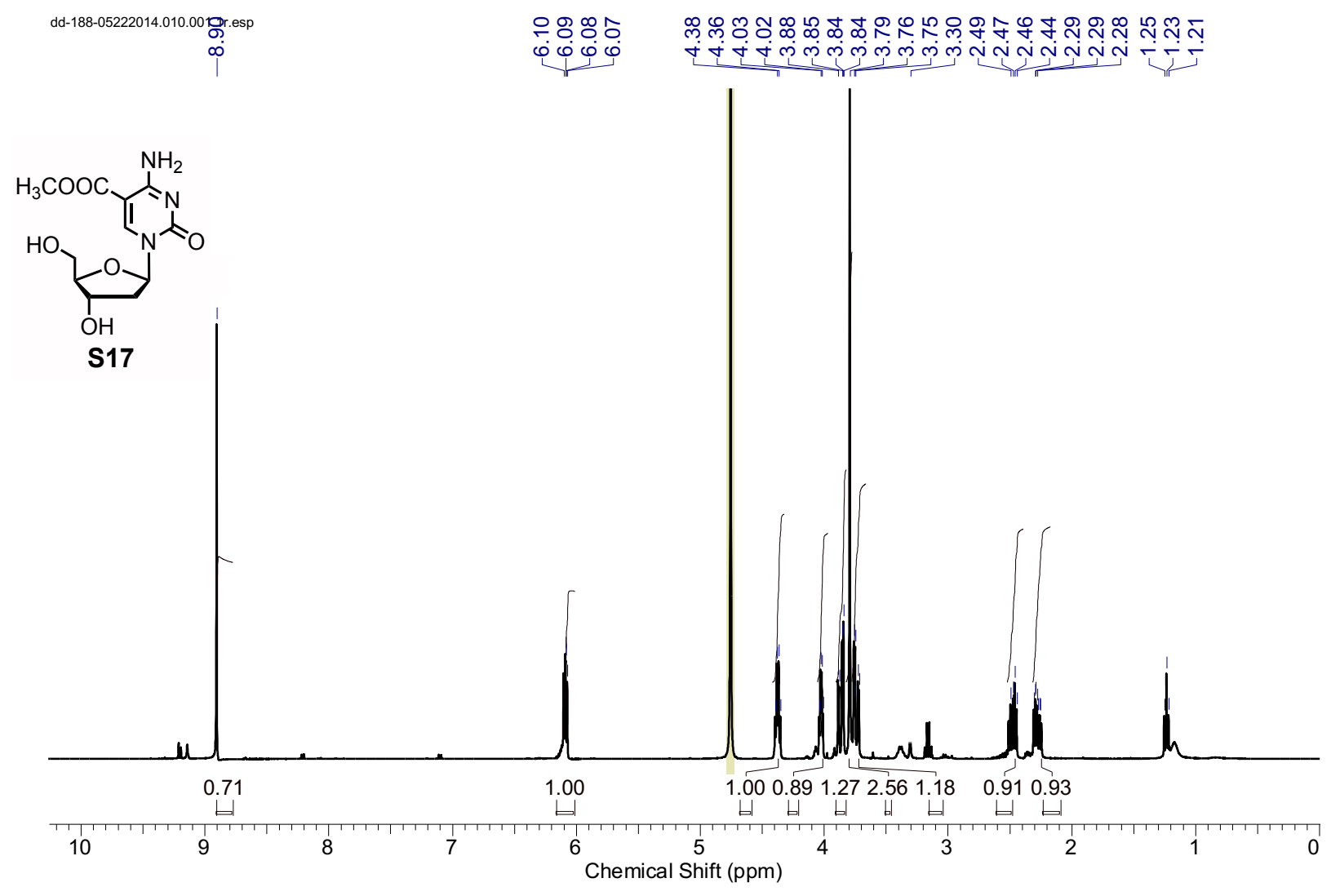

Supplementary Figure S39: ${ }^{1} \mathrm{H}$ NMR spectrum of $\mathbf{S 1 7}$ in $\mathrm{D}_{2} \mathrm{O}$. 
dd-193-05242014.010.001.1r.esp

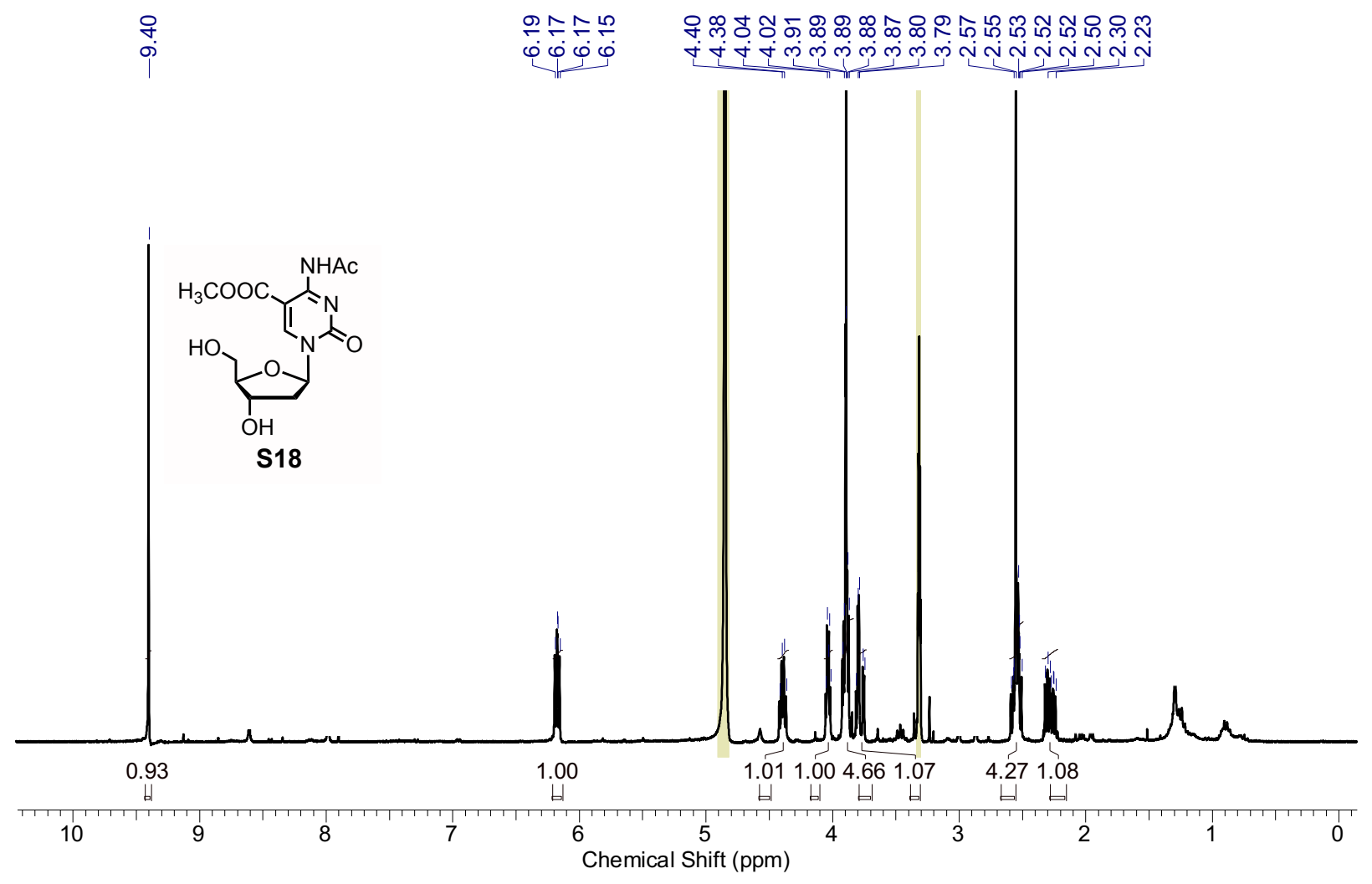

Supplementary Figure S40: ${ }^{1} \mathrm{H}$ NMR spectrum of $\mathbf{S 1 8}$ in $\mathrm{CD}_{3} \mathrm{OD}$. 


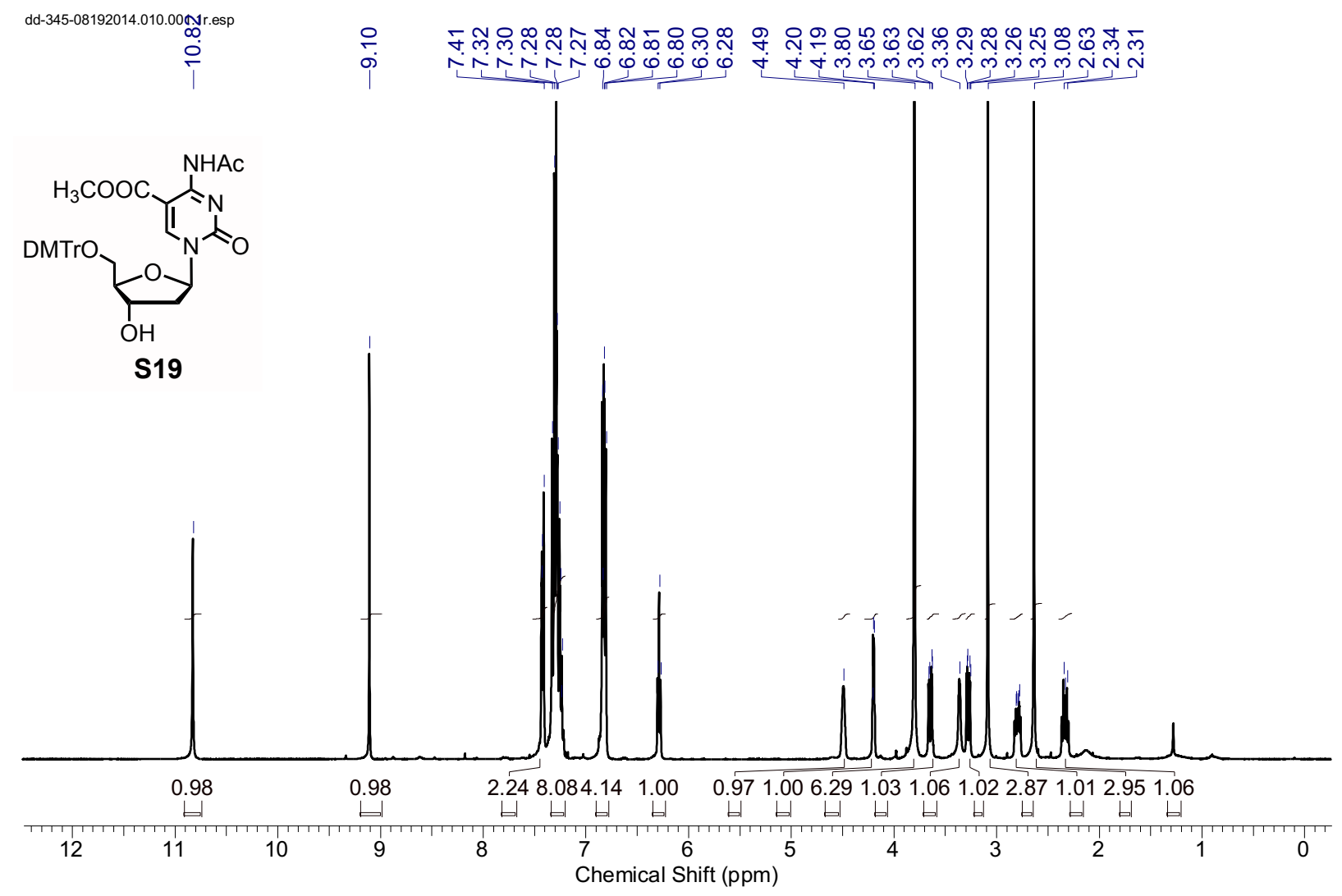

Supplementary Figure S41: ${ }^{1} \mathrm{H}$ NMR spectrum of $\mathbf{S 1 9}$ in $\mathrm{CDCl}_{3}$. 


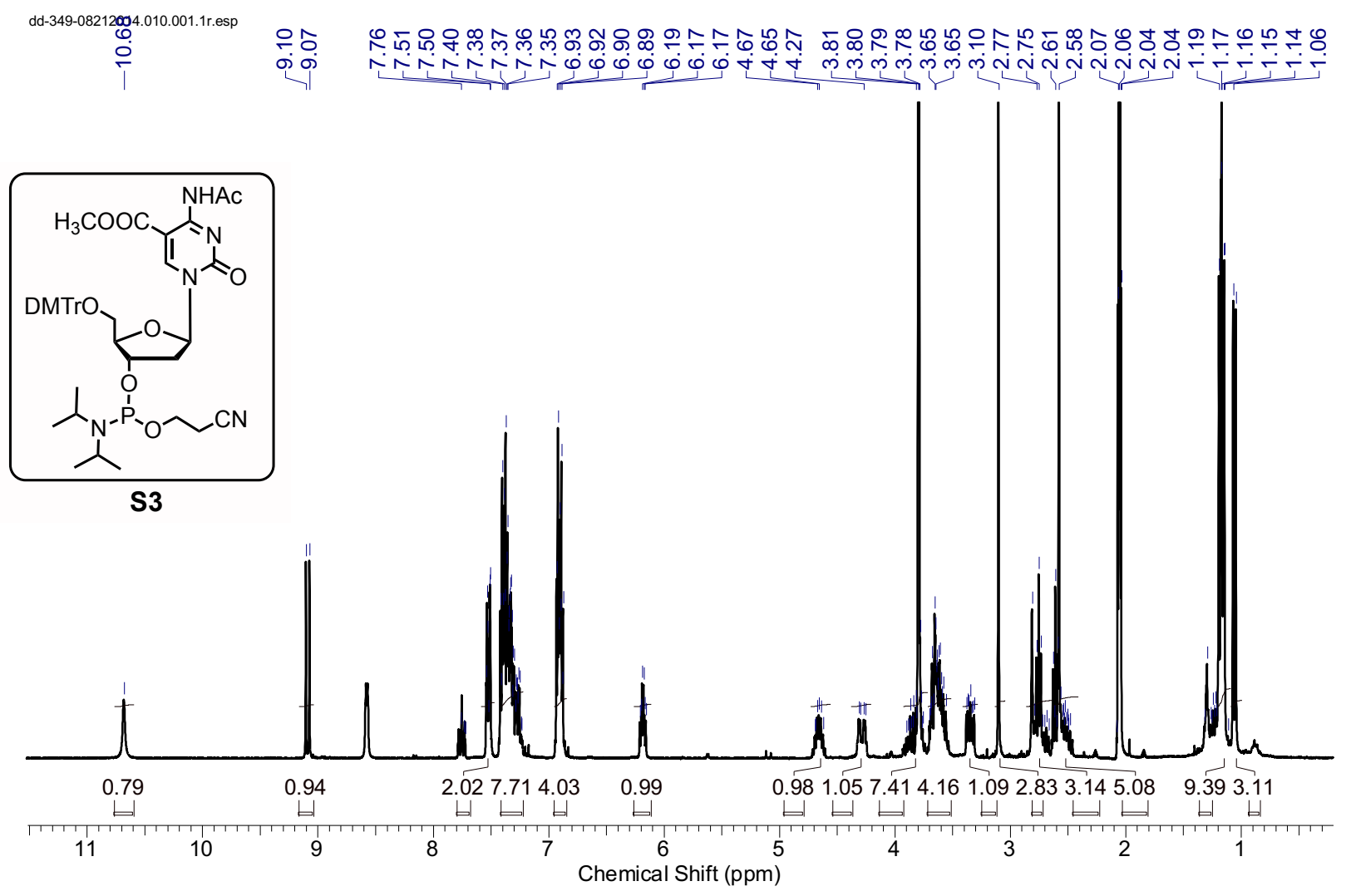

Supplementary Figure S42: ${ }^{1} \mathrm{H}$ NMR spectrum of $\mathbf{S 3}$ in $\mathrm{CD}_{3} \mathrm{COCD}_{3}$.

\begin{tabular}{|l|l|l|l|}
\hline GENE & VECTOR & AFFINITY TAG & RESISTANCE \\
\hline hTET2-CD & pcDNA3.1(+) & N-FLAG & Ampicilin \\
\hline TET2 & pPEI & N-6xHis & Kanamycin \\
\hline TET1 & pPEI & N-6xHis & Kanamycin \\
\hline
\end{tabular}

Supplementary Table S2. List of the genes used in the current study. The expression vector, antibiotic resistance and the affinity tag present for protein purification are provided. 


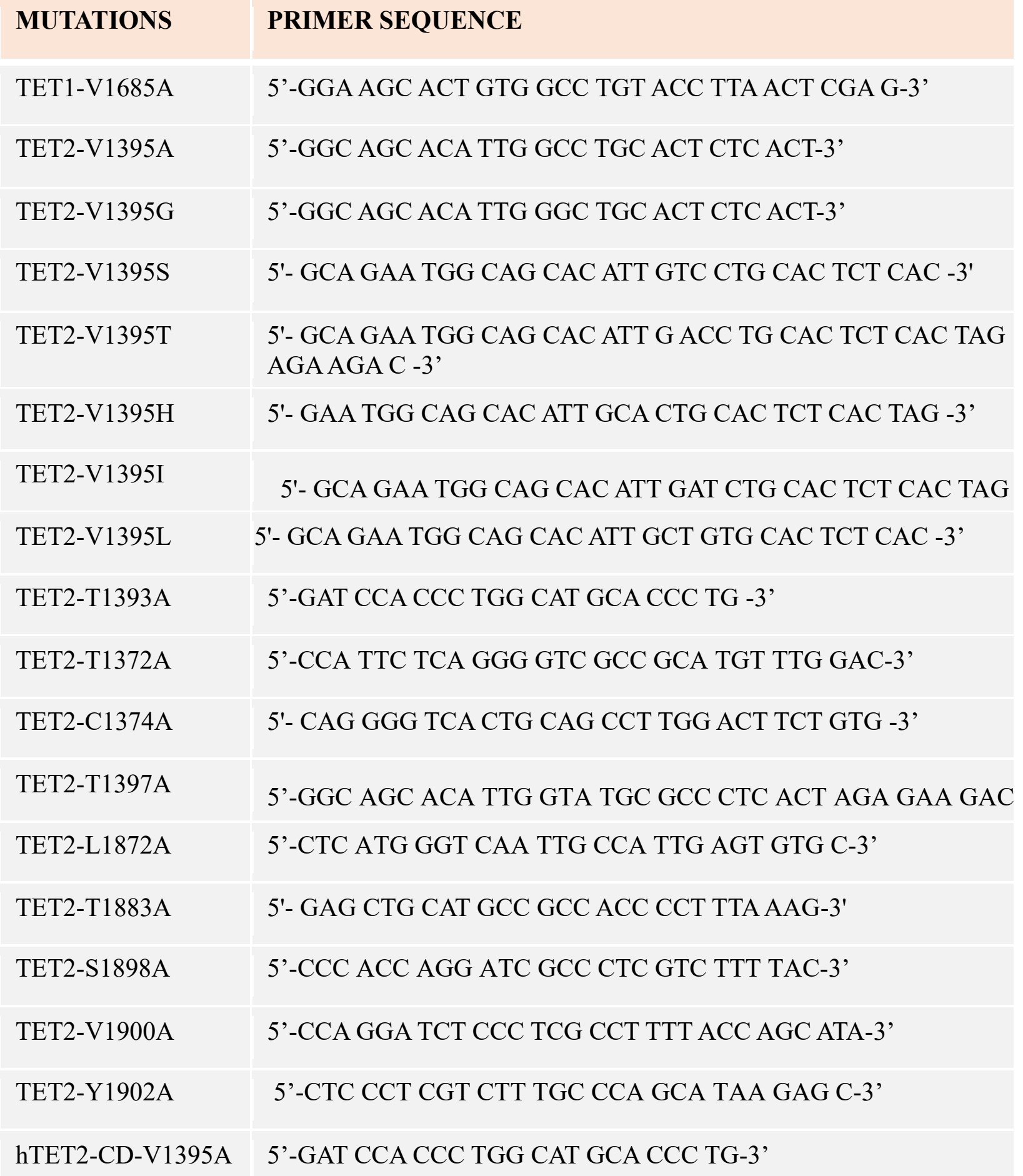

Supplementary Table S3. List of primers designed for site-directed mutagenesis. The reverse primers used are the reverse-complement to the given forward primers. 


\section{PROTEINS}

TET2-WT

TET2-V1395A

TET2-V1395G

TET2-V1395S

TET2-V1395T

TET2-V1395H

TET2-V1395F

TET2-V1395I

TET2-V1395L

TET2-V1395N

TET2-V1395D

TET2-T1393A

TET1-WT

TET1-V1685A

TET2-T1372A

TET2-C1374A

TET2-T1397A

TET2-L1872A

TET2-T1883A

\section{BACTERIAL CELLS FOR EXPRESSION}

BL21 [DE3] Star

BL21 [DE3] Star

BL21 [DE3] Star

BL21 [DE3] Star

BL21 [DE3] Star

BL21 [DE3] Star

BL21 [DE3] Star

BL21 [DE3] Star

BL21 [DE3] Star

BL21 [DE3] Star

BL21 [DE3] Star

BL21 [DE3] Star

BL21 [DE3] Star

BL21 [DE3] Star

BL21 [DE3] Star

BL21 codon plus [DE3] RIPL

BL21 [DE3] Star

BL21 [DE3] Star

BL21 codon plus [DE3] RIPL 
TET2-S1898A

BL21 [DE3] Star

TET2-V1900A

BL21 codon plus [DE3] RIPL

Supplementary Table S4. List of competent bacterial cells used in the current study for the expression of indicated proteins.

\begin{tabular}{|l|l|l|}
\hline OLIGONUCLEOTIDES & SEQUENCE & MW (Da) \\
\hline 5mC-DNA 8-mer & 5'-CAC5mCGGTG-3' (palindromic sequence) & 2424.059 \\
\hline 5hmC-DNA 8-mer & 5'-CAC5hmCGGTG-3' (palindromic sequence) & 2438.996 \\
\hline 5fC-DNA 8-mer & 5'-CAC5fCGGTG-3' (palindromic sequence) & 2436.910 \\
\hline 5 caC-DNA 8-mer & 5'-CAC5caCGGTG-3' (palindromic sequence) & 2453.240
\end{tabular}

Supplementary Table S5. List of DNA used in the current study as substrates of DNA demethylases.

\begin{tabular}{l|l}
\hline GENE & PRIMER SEQUENCE \\
\hline MIR200a & $\begin{array}{l}\text { Fwd: 5'-GGC TTC CAC AGC AGC CCC TG -3' } \\
\text { Rev: 5'-GAC ACC ACC GAG GCA CAT CC-3' }\end{array}$ \\
\hline MIR200b & $\begin{array}{l}\text { Fwd: 5'-GAG CTT CCC AGC GAG TCC CAT GC -3' } \\
\text { Rev: 5'-GTA ATG ATG ACG GCG GAG CCC TGC -3' }\end{array}$ \\
\hline MIR200c & $\begin{array}{l}\text { Fwd: 5'- GAA GCT GCC TGA CCC AAG GTG G -3' } \\
\text { Rev: 5'- GGA AGC CCC TCG TCT TGA GC -3' }\end{array}$ \\
\hline MIR429 & $\begin{array}{l}\text { Fwd: 5'- GCC TTC CCT TCA CAG GCC -3' } \\
\text { Rev: 5'- CCT GAT CAC CGT TAG AGG AGA GAG -3' }\end{array}$ \\
\hline SOX17 & $\begin{array}{l}\text { Fwd: 5'- GCCCTTCACGTGTACTACGG-3' } \\
\text { Rev: 5'- CTTCCTGCACGGCCTGGCTGAG-3' }\end{array}$ \\
\hline TCL1A & $\begin{array}{l}\text { Fwd: 5'- GTGGAGAAGACACAGGCATAG-3' } \\
\text { Rev: 5'- TGGTGCTGCTGGAGCAGGTCTAAGTG-3' }\end{array}$ \\
\hline Epcam & $\begin{array}{l}\text { Fwd: 5'-CAAGCTGGCCGTAAACTGC -3' } \\
\text { Rev: 5'- GATGTGCCTTGAGTTGG-3' }\end{array}$
\end{tabular}


TTR

Fwd: 5'- CATGAACAAAGCCACGCATG-3'

Rev: 5'- ATTCTTTTCCTCCTGGCCGA-3'

Supplementary Table S6. List of primers designed for DNA immunoprecipitation followed by qPCR assay.

\section{References}

(1) Dai, Q.; Song, C. X.; Pan, T.; He, C., Syntheses of two 5-hydroxymethyl-2'-deoxycytidine phosphoramidites with TBDMS as the 5-hydroxymethyl protecting group and their incorporation into DNA. J. Org. Chem. 2011, 76, 4182-8.

(2) Dai, Q.; He, C., Syntheses of 5-formyl- and 5-carboxyl-dC containing DNA oligos as potential oxidation products of 5-hydroxymethylcytosine in DNA. Org. Lett. 2011, 13, 3446-9.

(3) Schroder, A. S.; Steinbacher, J.; Steigenberger, B.; Gnerlich, F. A.; Schiesser, S.; Pfaffeneder, T.; Carell, T., Synthesis of a DNA promoter segment containing all four epigenetic nucleosides: 5-methyl-, 5-hydroxymethyl-, 5-formyl-, and 5-carboxy-2'-deoxycytidine. Angew. Chem. Int. Ed. 2014, 53, 315-8.

(4) Münzel, M.; Lischke, U.; Stathis, D.; Pfaffeneder, T.; Gnerlich, F. A.; Deiml, C. A.; Koch, S. C.; Karaghiosoff, K.; Carell, T., Improved synthesis and mutagenicity of oligonucleotides containing 5-hydroxymethylcytosine, 5-formylcytosine and 5-carboxylcytosine. Chemistry 2011, 17, 13782-8.

(5) Münzel, M.; Globisch, D.; Trindler, C.; Carell, T., Efficient synthesis of 5hydroxymethylcytosine containing DNA. Org. Lett. 2010, 12, 5671-3.

(6) Hu, L.; Li, Z.; Cheng, J.; Rao, Q.; Gong, W.; Liu, M.; Shi, Y. G.; Zhu, J.; Wang, P.; Xu, Y., Crystal structure of TET2-DNA complex: insight into TET-mediated 5mC oxidation. Cell 2013, 155, 1545-55.

(7) Hu, L.; Lu, J.; Cheng, J.; Rao, Q.; Li, Z.; Hou, H.; Lou, Z.; Zhang, L.; Li, W.; Gong, W.; Liu, M.; Sun, C.; Yin, X.; Li, J.; Tan, X.; Wang, P.; Wang, Y.; Fang, D.; Cui, Q.; Yang, P.; He, C.; Jiang, H.; Luo, C.; Xu, Y., Structural insight into substrate preference for TET-mediated oxidation. Nature 2015, 527, 118-22.

(8) Sudhamalla, B.; Wang, S.; Snyder, V.; Kavoosi, S.; Arora, S.; Islam, K., Complementary Steric Engineering at the Protein-Ligand Interface for Analogue-Sensitive TET Oxygenases. $J$. Am. Chem. Soc. 2018, 140, 10263-10269.

(9) Kavoosi, S.; Sudhamalla, B.; Dey, D.; Shriver, K.; Arora, S.; Sappa, S.; Islam, K., Siteand degree-specific $\mathrm{C}-\mathrm{H}$ oxidation on 5-methylcytosine homologues for probing active DNA demethylation. Chem. Sci. 2019, 10, 10550-10555.

(10) Sudhamalla, B.; Dey, D.; Breski, M.; Islam, K., A rapid mass spectrometric method for the measurement of catalytic activity of ten-eleven translocation enzymes. Anal. Biochem. 2017, 534, 28-35.

(11) Wei, S.; Shalhout, S.; Ahn, Y. H.; Bhagwat, A. S., A versatile new tool to quantify abasic sites in DNA and inhibit base excision repair. DNA Rep. 2015, 27, 9-18.

(12) Lu, X.; Song, C. X.; Szulwach, K.; Wang, Z.; Weidenbacher, P.; Jin, P.; He, C., Chemical modification-assisted bisulfite sequencing (CAB-Seq) for 5-carboxylcytosine detection in DNA. J. Am. Chem. Soc. 2013, 135, 9315-7. 
(13) Perell, G. T.; Mishra, N. K.; Sudhamalla, B.; Ycas, P. D.; Islam, K.; Pomerantz, W. C. K., Specific Acetylation Patterns of H2A.Z Form Transient Interactions with the BPTF Bromodomain. Biochem. 2017, 56, 4607-4615.

(14) Wang, Y.; Xiao, M.; Chen, X.; Chen, L.; Xu, Y.; Lv, L.; Wang, P.; Yang, H.; Ma, S.; Lin, H.; Jiao, B.; Ren, R.; Ye, D.; Guan, K. L.; Xiong, Y., WT1 recruits TET2 to regulate its target gene expression and suppress leukemia cell proliferation. Mol. Cell 2015, 57, 662-673.

(15) Lentini, A.; Lagerwall, C.; Vikingsson, S.; Mjoseng, H. K.; Douvlataniotis, K.; Vogt, H.; Green, H.; Meehan, R. R.; Benson, M.; Nestor, C. E., A reassessment of DNAimmunoprecipitation-based genomic profiling. Nat. Methods 2018, 15, 499-504.

(16) Hu, X.; Zhang, L.; Mao, S. Q.; Li, Z.; Chen, J.; Zhang, R. R.; Wu, H. P.; Gao, J.; Guo, F.; Liu, W.; Xu, G. F.; Dai, H. Q.; Shi, Y. G.; Li, X.; Hu, B.; Tang, F.; Pei, D.; Xu, G. L., Tet and TDG mediate DNA demethylation essential for mesenchymal-to-epithelial transition in somatic cell reprogramming. Cell Stem Cell 2014, 14, 512-22.

(17) Lewis, L. C.; Lo, P. C.; Foster, J. M.; Dai, N.; Corrêa, I. R.; Durczak, P. M.; Duncan, G.; Ramsawhook, A.; Aithal, G. P.; Denning, C.; Hannan, N. R.; Ruzov, A., Dynamics of 5carboxylcytosine during hepatic differentiation: Potential general role for active demethylation by DNA repair in lineage specification. Epigenetics 2017, 12, 277-286.

(18) Kent, W. J.; Sugnet, C. W.; Furey, T. S.; Roskin, K. M.; Pringle, T. H.; Zahler, A. M.; Haussler, D., The human genome browser at UCSC. Genome Res. 2002, 12, 996-1006. 